\title{
Processos de Comunicação e Cultura Local: um estudo sobre a Rádio Paraitinga, de São Luis do Paraitinga, SP
}

Dissertação apresentada ao Departamento de Cinema, Rádio e Televisão da Escola de Comunicações e Artes da Universidade de São Paulo como exigência parcial à obtenção do grau de Mestre em Ciências da Comunicação, sob a orientação do Prof. Dr. Angelo Pedro Piovesan Neto. 
ROSANA BENETON

\section{Processos de Comunicação e Cultura Local: um estudo sobre a Rádio Paraitinga, de São Luis do Paraitinga, SP}

Dissertação de Mestrado

Área de Concentração - Comunicação e Estética do Audiovisual Linha de Pesquisa - Sistemas de Significação em Imagem e Som

Orientador: Prof. Dr. Angelo Pedro Piovesan Neto 


\section{BANCA EXAMINADORA}

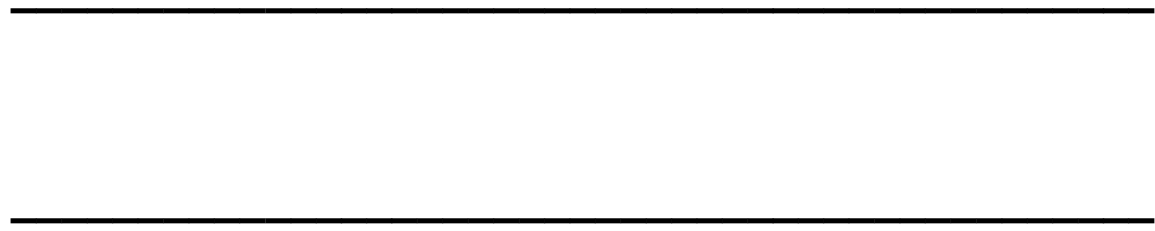

Data: $\_$I I 


\section{AGRADECIMENTOS}

Ao Prof. Dr. Angelo Pedro Piovesan, meu orientador e amigo.

Ao Senac e meus colegas que suavizaram as dificuldades, em especial à amiga Soledad.

Ao Renato S. de Lima e à Eliana Bordini, da Fundação SEADE, pelas valiosas contribuições.

Ao povo de São Luis do Paraitinga pela carinhosa acolhida que me permitiu viver esta experiência e este aprendizado.

Ao Juan por compreender e sempre apoiar.

Ao Lipe e à Cris, a quem dedico este trabalho, pelo incentivo de sempre. 


\section{SUMÁRIO}

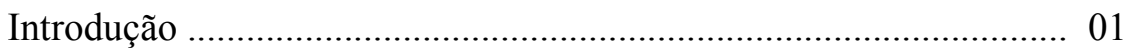

I. Os processos comunicacionais e a transformação da cultura ............ 06

1.1. Os processos da mundialização da cultura................................ 12

1.2. As possibilidades alternativas da radiodifusão......................... 18

1.2.1. Por uma teoria de rádio comunitária ............................. 23

1.2.2. A rádio comunitária no Brasil ..................................... 30

1.2.3. Rádio comunitária - uma demanda aos direitos à comunicação e à cidadania .............................................. 33

II. Identidade cultural e a força de sua expressão para a comunidade... 39

2.1. Cultura e identidade cultural .................................................. 41

2.2. Identidade cultural, identidade nacional e a formação

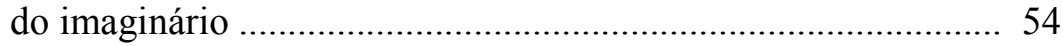

2.3. As manifestações culturais populares ....................................... 61

III. São Luis do Paraitinga e a tradição festeira do Vale do Paraíba ....... 69

3.1. O Vale do Paraíba histórico e cultural ..................................... 69

3.2. A cidade luizense.................................................................... 73

3.3. As celebrações coletivas do Vale do Paraíba ............................. 80

3.4. São Luis do Paraitinga, lugar de festa o ano inteiro..................... 83

IV. A Rádio Paraitinga e as relações com as manifestações

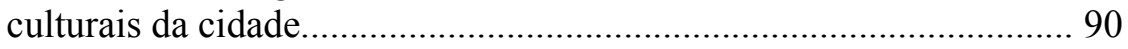

4.1. Apresentação do trabalho de campo......................................... 90

4.2. Identificação das manifestações culturais da cidade................... 95

4.3. Os processos comunicacionais hegemônicos e suas relações com a cultura local..................................................... 102

4.4. A Rádio Paraitinga e as manifestações culturais da cidade........ 106

4.4.1. A programação da Rádio Paraitinga.......................................107

4.4.2. A Rádio Paraitinga e seus ouvintes ......................................109

4.4.3. A Rádio Paraitinga: no horizonte do possível.........................119

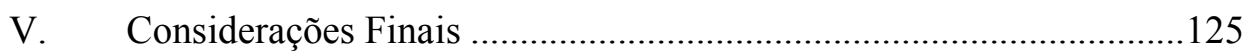

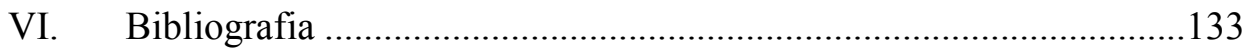

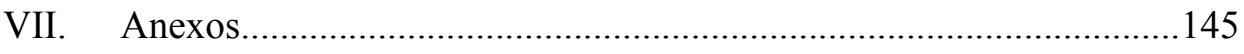

7.1. Mapa do Vale do Paraíba

7.2. Formulário-teste

7.3. Formulário final

7.4. Mapa da cidade e divisão em subáreas de aplicação

7.5. Tabulação dos dados

7.6. Autorização de Uso de Radiofreqüência da Rádio Paraitinga 


\section{RESUMO}

Esta dissertação trata da importância da preservação da cultura local, na cidade de São Luis do Paraitinga, no interior do Estado de São Paulo. O sentimento de pertencer a um grupo, partilhando valores, ideais e crenças comuns motiva essa população a comemorar e dessa forma preservar suas festas tradicionais, uma rica e diversificada cultura popular.

A pesquisa aqui apresentada buscou conhecer como os processos comunicacionais dessa localidade se relacionam com as suas manifestações culturais, mas deteve-se no estudo da comunicação radiofônica, com ênfase na rádio comunitária da cidade. Foi procurar indícios de como a Rádio Paraitinga pode estabelecer um processo comunicacional, em comunhão com a concepção de vida, dos valores éticos, estéticos, artísticos e religiosos da comunidade. Como compreende, participa e desenvolve os laços de identidade e de pertencimento. Como a comunidade se identifica com a Rádio. Como vinculam sua intensa vivência do cotidiano à emissora.

O estudo apresenta, em suas considerações finais, importantes dados indicadores do quanto a rádio da cidade responde a essas questões e sugere ações para que ela efetivamente exerça seu papel junto à comunidade, ações que realmente possam identificá-la como comunitária e, dessa forma, contribuir para a preservação das manifestações culturais.

\section{PALAVRAS-CHAVE}

cultura local - tradições - identidade cultural - processos comunicacionais rádio comunitária. 


\begin{abstract}
This study says about the importance of the local culture preservation, in the city of São Luis do Paraitinga, interior of São Paulo. The feeling of belonging to a group, sharing values, ideals and common beliefs motivate this population to celebrate and therefore preserve their folk festivities, a rich and diversity popular culture.
\end{abstract}

The following research meant to know how the communicational processes of this place relate to their culture manifestations, but privileged the radiophonic communication, focusing the city community radio. Searched hints how the Paraitinga Radio can establish a communication process, in congruent with their life conceptions, ethical, aesthetical, artistical and religious values. As understanding, sharing and developing their identity and belonging bonds. As the community identify itself with the Paraitinga Radio. As sharing their intense way of life with the radio station.

In its final considerations, the research shows important indicating data of how the city radio answer this questions and its recommends actions that can really identify than as community and therefore to contribute to the preservation of the cultural manifestations.

\title{
KEY WORDS
}

local culture - traditions - cultural identity - communications processes community radio. 
INTRODUÇÃO 


\section{Introdução}

Os meios de comunicação de massa, sobretudo os de acesso mais fácil e menos dispendioso à população, são importantes agentes de mudança nos seus hábitos, costumes e valores. Entre eles, o rádio e a televisão são, provavelmente, os que têm importante papel na construção da cultura de um povo, uma vez que a maioria dos lares, tem pelo menos um aparelho de rádio e um televisor.

Dada a portabilidade do rádio, esse meio exerce então uma importância ainda maior. A transmissão de informações e de fatos on time permite ao comunicador radialista um papel inquestionável de influência na formação do julgamento de seus ouvintes sobre os acontecimentos.

Pouca importância se atribui às conseqüências e reflexos da programação radiofônica no que se refere à preservação da identidade cultural de uma comunidade. Além do valor atribuído ao fato de levar aos ouvintes das regiões mais distantes a informação sobre os acontecimentos do país e do mundo, o meio radiofônico é também responsável pelo entretenimento. É por meio do entretenimento que a comunicação pode se tornar um importante instrumento de influência na cultura local.

A programação radiofônica possibilita o conhecimento da cultura de outros povos, sua música, sua língua e seus valores, e oferece ao ouvinte um mundo, por vezes, muito diferente do seu cotidiano. Ampliar seus horizontes para o que se passa no mundo é, sem dúvida, uma ação do rádio a serviço da cultura geral de uma comunidade.

Por outro lado, é necessário uma identificação do homem com a comunidade em que vive. O sentimento de pertencer a um grupo, partilhar ideais, identificar valores e crenças comuns aos seus membros, participar de ações que o identificam como agente dessa comunidade, são fatores que dão 
significado à vida de uma pessoa num determinado lugar e num determinado período.

Com base nas leituras realizadas ao longo da preparação para a elaboração desta dissertação, pode-se apreender que a cultura compartilhada pelos habitantes de um local, com seus valores próprios, sofre a influência dos processos hegemônicos dos meios de comunicação de massa. Muitas das festas tradicionais de pequenas localidades, de profundo significado para a comunidade, vêm perdendo pouco a pouco sua genuinidade e suas características culturais. A vida das pequenas cidades tem sido alterada, paulatinamente, pelas influências que as pessoas sofrem no seu modo de pensar e, consequentemente, de agir. Influências estas que, certamente, passam pela ação dos meios massivos de comunicação.

Este trabalho trata das potencialidades do processo comunicacional radiofônico, com ênfase na radiodifusão comunitária, numa cidade do interior do Estado de São Paulo, no que diz respeito a sua participação como agente atuante na preservação das suas tradições culturais. Visa contribuir para o desenvolvimento de uma teoria que aborde a influência dos processos comunicacionais sobre as culturas locais.

A cidade em foco é São Luis do Paraitinga, com uma área de 737 quilômetros quadrados e fica a $170 \mathrm{~km}$ da capital paulista, entre Taubaté e Ubatuba. Apresenta arquitetura típica do século XVIII, com seus casarões cuidadosamente restaurados, inspirados nas moradias do Rio de Janeiro, na época em que era capital do Império. Tem sacadas, janelas tipo guilhotina e portas com bandeiras de ferro trabalhadas e em muitas delas está gravada, na parte superior, a data de sua construção. Muitos desses casarões foram tombados pelo CONDEPHAAT - Conselho de Defesa do Patrimônio Histórico, Arqueológico e Turístico do Estado, em 1977, constituindo o maior conjunto arquitetônico colonial do Estado de São Paulo. Em vários documentos, folhetos, sites consultados foram encontradas duas formas de denominação da cidade, em algumas delas encontra-se Luis escrito com S e outras Luiz com Z. 
Esta pesquisadora optou por adotar Luis com S, por julgar que essa é a forma mais usual e mais genuína.

A cidade conserva muitos costumes seculares que desapareceram na maioria das cidades e muitas manifestações de cultura popular compõem hoje o seu calendário festivo oficial. São famosos os festivais de marchinhas carnavalescas nos quais é escolhido o único repertório a ser tocado durante todo o período do Carnaval na cidade, que ainda é brincado na rua, com seus blocos carnavalescos, num clima alegre e familiar. Outros festivais de músicas, caipiras e juninas, privilegiam seus compositores. A cidade foi berço de Elpídio dos Santos, compositor de todas as músicas dos filmes de Mazzaropi, além de outras canções gravadas por importantes artistas da música popular brasileira. Por essas razões, a cidade foi escolhida para objeto deste trabalho, por sua rica e diversificada cultura popular festejada durante todo o ano.

A rádio analisada é a Rádio Paraitinga FM, 105.9, freqüência sintonizada no dial de quem entra na cidade, uma rádio comunitária, a única emissora de São Luis do Paraitinga e a que melhor pode ser ouvida. Preferida pela maioria da população urbana pesquisada, embora na cidade também possa ser sintonizada uma emissora de um grande conglomerado globalizado, a Paraitinga despertou interesse por causa dessa audiência, desde cedo registrada nas ações exploratórias deste trabalho.

O primeiro capítulo, OS PROCESSOS COMUNICACIONAIS E A TRANSFORMAÇÃO DA CULTURA, buscará conhecer a ação da grande mídia, em especial os processos hegemônicos de comunicação sobre as identidades dos povos recobrindo-os de novos sentidos, modificando seu imaginário cultural e convergindo para o sentido da unicidade mundial. Vai procurar discutir as possibilidades alternativas da radiodifusão e nela destacar a participação da radiodifusão comunitária enquanto conceito.

O segundo capítulo, IDENTIDADE CULTURAL E A FORÇA DE SUA EXPRESSÃO PARA A COMUNIDADE, tratará dos processos culturais enquanto elemento de construção de identidade de um povo, importante para 
construção da memória coletiva, através da manutenção de suas tradições. Buscará discutir os conceitos de identidade cultural e identidade nacional, levantando as condições do poder vertical unificador das mídias e o nascimento de novas identidades regionais e locais, suportadas pela valorização do direito a raízes como necessidade de resistência para manter suas tradições. Nelas, as manifestações populares permitem as práticas vividas no cotidiano, realizadas na busca do estar junto coletivo, levando ao sentimento de pertencimento.

O terceiro capítulo, SÃO LUIS DO PARAITINGA E A TRADIÇÃO FESTEIRA DO VALE DO PARAIBA, vai apresentar as origens da região valeparaibana e das suas manifestações culturais populares. Também apresentará a cidade de São Luis do Paraitinga como reduto de tradições centenárias e as razões que a fizeram ser considerada Estância Turística, o que tem exigido da pacata cidade repensar suas ações culturais. Além disso, pretenderá identificar suas principais manifestações culturais para compreender os valores amalgamados na identidade ou no imaginário cultural da comunidade.

O quarto capítulo, A RÁDIO PARAITINGA E AS RELAÇÕES COM AS MANIFESTAÇÕES CULTURAIS DA CIDADE, vai apresentar a metodologia utilizada para obter os dados resultantes do trabalho de campo e a articulação desses dados com o referencial teórico no qual está embasada a pesquisa. Analisará os processos radiofônicos da região para compreender as possíveis relações que possam denunciar a influência da hegemonia dos processos comunicacionais sobre o cotidiano da cidade. Procurará ainda analisar a atuação da Rádio Paraitinga, conhecer sua programação e seus ouvintes, para compreender as possíveis relações estabelecidas com as manifestações culturais da cidade.

Finalmente o trabalho vai apresentar considerações que permitirão indicar algumas ações com o intuito de contribuir para a construção de uma nova relação da emissora com a cidade, bem como levantará questionamentos passíveis de constituir novos estudos. 


\section{CAPÍTULO 1}

Os Processos Comunicacionais e a Transformação da Cultura 


\title{
1. Os Processos Comunicacionais e a Transformação da Cultura
}

\author{
"O rádio seria o mais fabuloso aparato de \\ comunicação imaginável na vida pública, ...se \\ em vez de apenas transmitir pudesse também \\ receber; quer dizer, o ouvinte não deve apenas \\ ouvir, mas o rádio deveria fazê-lo falar."
}

Bertold Brecht ${ }^{1}$

Os meios de comunicação envolvem as pessoas, indiscriminadamente, com uma presença da qual é difícil se escapar. As pessoas permanecem sempre ao alcance de um desses meios ou de vários, simultaneamente, como televisão, rádio, jornal, revistas, internet, outdoors, em shoppings ou supermercados.

Dentro de suas casas ou nos espaços públicos, a mídia lhes oferece produtos, serviços e entretenimento com insistência que se impõe como uma demanda indispensável, criando novas necessidades de consumo. A onipresença e a influência da mídia cristalizam o papel veiculador e produtor de valores, prioridades e perspectivas hegemônicas.

Desta forma, a mídia exerce influência direta na configuração dos imaginários sociais, supervalorizando crenças, hábitos e estilos de vida muitas vezes sintonizadas com a febre de consumo dos mercados mundiais.

Vivemos um quadro de mutações que engloba, de um lado, o poderio das corporações transnacionais de informação e entretenimento, promovido pela globalização neoliberal, e de outro, ambientes virtuais e movimentos em rede com tendência a ideais participativos e à luta pela cidadania. O que se deseja é a comunicação que leve em conta a complexidade da era digital, mas que se baseie em políticas públicas capazes de evitar monopólios, descentralizar a produção simbólica e assegurar a diversidade cultural.

\footnotetext{
${ }^{1}$ Bertold BRECHT, Teorias de la radio - sugerencias a los directores artísticos de la radio, p. 86.
} 
Nesse cenário, também se insurgem, as mídias praticadas fora da expressão da indústria hegemônica, cujos agentes são sujeitos sociais movidos por projetos de intervenção crítica, que expressam posições alternativas às mídias dominantes. São experiências menos expressivas se comparadas com os setores de entretenimento de massa amparadas pelo capital global. Muitas vezes, são reduzidas a parcos recursos humanos, técnicos e financeiros, sendo até mesmo hostilizadas, perseguidas, boicotadas e relegadas à clandestinidade. Essas mídias dão ressonância às vozes discordantes ou minoritárias e são portadoras de um ideal de mudanças, como observa Arlindo Machado ${ }^{2}$.

Pretendem uma comunicação em que os sistemas globais de mídia não sufoquem identidades, laços comunitários, direitos coletivos e que elimine a distinção entre produtores e receptores, constituídos nos mesmos sujeitos sociais. Nesta perspectiva, os conceitos de verticalidade e de horizontalidade, aplicados respectivamente à formação de espaços empresariais (econômicos) e de espacialidades da vida cotidiana propostos por Milton Santos ${ }^{3}$, podem contribuir para o entendimento dos processos comunicacionais das mídias hegemônicas e das mídias alternativas e sua relação com a cultura.

Para Milton Santos, a globalização neoliberal domina a velocidade e a fluidez virtual, promovidas pelos avanços da técnica, principalmente, pelos sistemas de informação. A fluidez forma-se no imaginário e na ideologia como se fosse um bem comum, uma fluidez para todos, quando, na verdade, serve apenas a algumas empresas, agentes que têm a possibilidade de usá-la e de controlá-la, tornando-se "donos" da velocidade e da circulação rápida e incessante de informações e, consequentemente, das imposições do mercado.

Desta forma, quebra as antigas solidariedades horizontais para impor uma solidariedade vertical, cujo eixo é a empresa hegemônica, localmente

\footnotetext{
${ }^{2}$ Texto de Introdução. In John D.H. DOWNING, Midia Radical - Rebeldia nas Comunicações e Movimentos Sociais, p. 10.

${ }^{3}$ Milton SANTOS, Por uma outra globalização, do pensamento único à ciência, p. 105-107.
} 
obediente aos interesses globais mais poderosos e, desse modo, indiferente ao seu entorno, processo este que se identifica com a mídia hegemônica.

Ainda de acordo com Milton Santos, as solidariedades horizontais preexistentes num território refazem-se historicamente pelo debate interno, levando-as aos ajustes e à reconstrução da sua própria noção de solidariedade, valores contemplados pelas mídias alternativas, entre elas, a rádio comunitária.

Para manter seus objetivos, as empresas agem individualmente e suas ações raramente são coordenadas com outras ou com o poder público e, como conseqüência, agrava-se a desorganização local, reduzindo as possibilidades do exercício da busca do sentido para a vida social. O poder das grandes empresas globais é extremamente desagregador, excludente, fragmentador e elimina a autonomia dos demais atores. A lógica do mercado global caracteriza-se por dois aspectos: primeiro por sua sede distante do espaço da ação e, segundo, pela falta de sintonia e conformidade com o sentido preexistente da vida do território no qual se instala, produzindo uma verdadeira alienação territorial, de onde decorrem outras formas de alienação.

Quem comanda e centraliza a disseminação dos bens simbólicos pela grande mídia? Quem define o que vai ser produzido, como e onde divulgado? Que benefícios temos ao discutir apenas os temas midiáticos que a própria indústria hegemônica impõe?

Santos comenta que as verticalidades podem ser definidas, num território, como um conjunto de pontos formando um espaço de fluxos ${ }^{4}$. Esse espaço de fluxos seria, na realidade, um subsistema dentro da totalidadeespaço e o que conta é um conjunto de pontos adequados às tarefas produtivas hegemônicas, características das atividades econômicas que comandam o mundo atual. O sistema de produção que se serve desse espaço

\footnotetext{
${ }^{4}$ Milton SANTOS, Por uma outra globalização, do pensamento único à ciência, p. 111.
} 
de fluxos é constituído por redes - um sistema reticular - que exige a fluidez e a velocidade $^{5}$. Esses atores do tempo rápido são os que se aproveitam $\mathrm{e}$ participam do processo da fluidez, enquanto os demais ficam fora, não se beneficiando com ele.

Os espaços de fluxos formam uma solidariedade vertical, só mantendo a agregação e a cooperação por meio do processo organizacional, comandados pelos "macro-atores" que, de fora do território, comandam as modalidades internas da ação, adaptando os comportamentos locais aos interesses globais ${ }^{6}$. Os interesses globais estão sempre mudando, provocando as descontinuidades e o controle dos conjuntos de espaço, para o qual os Estados têm uma ação dissimulada, omissa ou protecionista aos atores hegemônicos.

Desse modo, os espaços de fluxos têm o papel de integração dos níveis econômicos e espaciais, mas é uma integração vertical, alienadora, cujas decisões, obedecendo a motivações distantes, impõem condições aos processos locais. Essa dominância é portadora da racionalidade hegemônica que facilita a busca da unificação. No modelo hegemônico, planejado para ser indiferente ao seu entorno, o território local é usado como um recurso, um uso pragmático assegurado pelos sistemas de informação.

As horizontalidades são zonas da contigüidade, é o "espaço banal", que se opõe ao espaço econômico. É o espaço de todos: empresas, instituições, pessoas; é o espaço das vivências, são espaços humanos. São espaços que sustentam e explicam um conjunto de produções localizadas, interdependentes, dentro de uma área, cujas características constituem também um fator de produção. Na mídia alternativa, é o público que elabora os seus produtos, em lugar de apenas absorver passivamente as mensagens disseminadas pela grande mídia. Nos espaços da horizontalidade, todos os

\footnotetext{
${ }^{5}$ Milton SANTOS, Por uma outra globalização, do pensamento único à ciência, p. 89 .

${ }^{6}$ Ibid., p. 105 a 111.
} 
agentes são implicados e os tempos, mais rápidos ou mais vagarosos, são imbricados, criando-se uma solidariedade orgânica que busca a união.

O conjunto das horizontalidades evolui e muda, num processo de continuidade. Nesse espaço "banal", a ação atual do Estado é limitada, além de ter as funções igualmente banais. $O$ fato de $\mathrm{O}$ Estado preocupar-se dominantemente com o desempenho das macro empresas, que desconhecem as particularidades criadas a partir do meio geográfico, leva à ampliação das verticalidades, mas, paralelamente, permite o aprofundamento das personalidades das horizontalidades, que, diante da presença das empresas, de técnicas, de capital e de organização, buscam a sobrevivência pela integração no processo da ação.

Forma-se, assim, a produção local de uma integração solidária, construída por meio das solidariedades horizontais internas, de natureza econômica, social, comunicacional, cultural e geográfica. O espaço das horizontalidades realiza-se em diversas temporalidades, enquanto que as verticalidades são regidas por um relógio único, global.

O espaço banal é o espaço do cotidiano e das solidariedades. E é o espaço da vocação solidária que impede que o poder crescente e invasivo dos atores hegemônicos, fundados nos espaços de fluxos, seja capaz de eliminar o espaço banal, que se reconstitui permanentemente, por meio de encontros e desencontros e do exercício do debate e dos acordos, buscando a readaptação às novas formas de vida. É também esse processo o que leva uma sociedade ou comunidade a buscar o sentido de sua existência ${ }^{7}$.

Assim, o território não é apenas o lugar de uma ação pragmática, mas é, acima de tudo, um aporte da vida, uma parcela de emoção, responsáveis, através da ação comunicativa, pelas mais diversas manifestações da

\footnotetext{
${ }^{7}$ Milton SANTOS, Por uma outra globalização, do pensamento único à ciência, p. 113-114.
} 
espontaneidade e da criatividade. Dessa forma, a mídia global separa, fragmenta, e a mídia alternativa local une, podendo construir os sentidos da realização plena da vida.

\subsection{Os processos da mundialização da cultura}

Os conglomerados de mídia e entretenimento exercem um papel estratégico na contemporaneidade, pois legitimam o ideário global e 0 transforma num discurso social hegemônico, disseminando visões de mundo e modos de vida, transferindo para o mercado a regulação das demandas coletivas, segundo Denis de Moraes ${ }^{8}$.

Os discursos da globalização tentam impor a certeza de que a fonte primeira da expressão cultural se mede pelo nível de consumo dos indivíduos. A chamada grande mídia fabrica o consenso sobre a superioridade das economias abertas, insistindo que não há saída pressupostos neoliberais. Seu eixo ideológico consiste em enquadrar o consumo como valor universal, capaz de converter necessidades, desejos e fantasias em bens integrados à ordem de produção.

As indústrias da informação e do entretenimento ancoram o terreno ideológico-cultural porque operam como máquinas produtoras que estruturam o capitalismo sem fronteira, afirma Moraes. A mídia passa a ocupar posição destacada no âmbito das relações produtivas sociais, visto que é no domínio da comunicação que se fixa a síntese ideológica - política da ordem hegemônica.

A mídia atua, assim, tanto por adesão à globalização neoliberal, quanto por deter a capacidade de interconectar o planeta, através de satélites, cabos de fibra óptica e redes infoeletrônicas. Não existe outra esfera da vida

\footnotetext{
${ }^{8}$ Dênis de MORAES (org.), Por uma outra comunicação - mídia, mundialização cultural e poder, 189194.
} 
cotidiana habilitada a interligar povos, países, sociedades, culturas e economia como a mídia.

Moraes afirma que a CNN, com matriz em Atlanta, distribui, por satélites e cabos, notícias 24 horas por dia para 160 milhões de lares em diferentes países e 81 milhões somente nos Estados Unidos, além de 890 mil quartos de hotéis conveniados. O mundo em tempo real quase sempre sob o prisma ideológico norte-americano. Com provável semelhança de números, mas certamente com ação tão abrangente, a BBC cobre o mundo 24 horas.

A articulação entre o modo de produção capitalista e as tecnologias de comunicação e informação resulta numa sinergia que alimenta a acumulação de capital financeiro numa economia de interconexões eletrônicas, e desta forma, os conglomerados de mídia reluzem como agentes econômicos globais, buscando alcançar os parâmetros da lucratividade que norteiam as ações dos gigantes transnacionais.

Em suma, as organizações de mídia projetam-se a um só tempo, como agentes discursivos, com uma proposta de coesão ideológica em torno da globalização e como agentes econômicos proeminentes nos mercados mundiais, vendendo os próprios produtos e intensificando a visibilidade de seus anunciantes.

\footnotetext{
"A mídia global está nas mãos de mais de duas dezenas de conglomerados, com receitas entre U\$ 5 milhões e U\$ 35 milhões. Eles veiculam dois terços das informações e dos conteúdos culturais disponíveis no planeta. Entrelaçam a propriedade de estúdios, produtoras, distribuidoras e exibidoras de filmes, gravadoras de discos, editoras, parques de diversões, TVs abertas e pagas, emissoras de rádio, revistas, jornais, serviços on line, provedores e portais da internet, vídeos, videogames, jogos, sofwares, CDs roms, DVDs, equipes esportivas, megastores, agências de publicidade, e marketing, telefonia celular, telecomunicações, transmissão de dados, agências de notícias e casas de espetáculos" ${ }^{\prime 9}$.
}

\footnotetext{
${ }^{9}$ Dênis de MORAES (org.), Por uma outra comunicação - mídia, mundialização cultural e poder, p.199.
} 
Estes conglomerados têm as mesmas pretensões: estar em toda parte, a qualquer tempo, exercendo domínio. Os conglomerados de mídia ficam definitivamente identificados como atores de primeira linha no processo de reprodução do capital em dimensão planetária.

Para Octávio lanni, ${ }^{10}$ as identidades dos mais diferentes povos e etnias, em diversas épocas, sempre foram ameaçadas pelos processos de globalização do mundo, e, diante das transformações, foram criadas expressões como civilizados e bárbaros, babel e humanidade, nativos e estrangeiros, primeiro e segundo mundos, Ocidente e Oriente, norte e sul, capitalismo e comunismo. Coexistia na noção de globalização o significado de bipolarização.

Porém, a partir do término da Guerra Fria, se desmorona a economia socialista e o mundo deixou de estar rigidamente polarizado entre o bloco soviético ou comunista e o bloco norte-americano ou capitalista, sobrando apenas a opção do capitalismo como mal necessário. Desde então, a globalização recobre-se de novos sentidos, todos eles convergindo para o sentido da unicidade mundial, que, como diz Milton Santos, é imposto aos espíritos, e aproveita-se do alargamento dos contextos para consagrar-se como um discurso único.

..."Seus fundamentos são a informação e o seu império, que encontram alicerce na produção de imagens e do imaginário, e se põem ao serviço do império do dinheiro, fundado este na economização e na monetarização da vida social e da vida pessoal". ${ }^{11}$

Entre os fatores constitutivos desta perversa globalização, encontra-se a forma como a informação é oferecida à humanidade e a emergência do dinheiro em estado puro, como o dínamo da vida econômica, social e cultural. Essas duas violências são os pilares que justificam as ações hegemônicas e

\footnotetext{
${ }_{11}^{10}$ Octávio IANNI, Teorias da Globalização, p. 24.

${ }^{11}$ Milton SANTOS, Por uma outra globalização, do pensamento único à consciência universal, p.18.
} 
levam ao império das fabulações, a percepções fragmentadas e ao discurso único, base do novo totalitarismo ou globaritarismo, do qual se multiplicam os sentidos da globalização neoliberal a que se assiste, afirma Santos.

Para o autor, o traço mais marcante do mundo contemporâneo é o papel despótico da informação. As novas condições técnicas deveriam permitir a ampliação do conhecimento do planeta, dos objetos que o formam, das sociedades que o habitam e dos homens na sua realidade interior. Mas, no entanto, nas condições atuais, as técnicas da informação são utilizadas por uma minoria em função de seus objetivos individuais, apropriadas por alguns Estados e por algumas empresas, aprofundando os processos de criação de desigualdades, tornando a periferia do sistema capitalista ainda mais periférica, porque não dispõe dos novos meios de produção e não podem ter o controle sobre eles.

A informação que é transmitida à humanidade é manipulada, e, ao invés de esclarecer, vem para confundir, apresentando-se como uma ideologia com duas faces: uma para instruir e outra para convencer, principalmente, por meio da publicidade. As mídias nacionais globalizam-se pelos ícones incessantemente presentes e os eventos são processados e entregues ao leitor, ao ouvinte, ao telespectador de forma maquiada, criando mitos e fábulas.

\section{Para Santos,}

"A violência da informação, diz Santos, serve à violência do dinheiro". Na fase atual da história, a internacionalização do capital financeiro amplia-se por diversas razões. As megafirmas devem, obrigatoriamente, centrar-se no uso financeiro do dinheiro que obtém e nesse cenário, o financeiro ganha uma espécie de autonomia. O dinheiro, em estado puro, se torna despótico porque tudo também se tornou valor de troca. A monetarização da vida cotidiana ganhou um enorme terreno nos últimos vinte e cinco anos do século $X X$, ameaçando a própria vida cotidiana.

O centro do mundo não é mais voltado para indivíduo, tomado singularmente como classe, grupo, minoria, opinião pública, pois são absorvidos, real ou 
formalmente, pela sociedade global, pelas configurações e movimentos da globalização neoliberal" ${ }^{12}$...

Deu-se forma a uma comunidade mundial, construída pelo desenvolvimento da comunicação, da informação e das imaginações abertas pela eletrônica, e indica que estão em curso a harmonização e a hegemonização progressivas. Fundamenta-se no argumento de que a organização, o funcionamento e a mudança da vida social, em sentido amplo, são ocasionados pela técnica, mais precisamente, pela eletrônica. Em pouco tempo, as nações, províncias e regiões, bem como as culturas e civilizações são atravessadas e articuladas pelos sistemas de informação, de comunicação e imaginações agilizadas pela eletrônica.

Sua linguagem e seus significados são impostos à vida das pessoas de todos os lugares, dando contornos hegemônicos ao seu pensamento, ao seu sentimento, ao seu gosto e às suas ações, transformando o imaginário de todas as sociedades do mundo.

Afirma Moraes $^{13}$ que esses signos prefiguram uma memória coletiva partilhada por pessoas de todos os lugares do mundo. Não se trata mais de uma memória enraizada em tradições regionais e locais, mas traçada e reconhecível em estilos de vida, cujos entornos simbólicos suplantam as suas especificidades históricas e facilitam planejamentos mundializados.

Para o autor, os grupos sociais de diversos continentes, e de diferentes etnias, e de crenças, passam a agregar-se em torno de símbolos universais e desterritorializados, tais como: Big Mac, pizza express, excursões à Disneylândia, Programa Windows, símbolos estes presentes no cotidiano das pessoas, inscritos no seu imaginário, descolando os sentimentos de pertencimento das lealdades locais que passam a ser regidos e influenciados pelos centros gestores do consumo ${ }^{14}$.

\footnotetext{
${ }^{12}$ Milton SANTOS, Por uma outra globalização, do pensamento único à consciência universal, p. 39-56.

${ }_{14}^{13}$ Dênis de MORAES, O Planeta Mídia - Tendências da Comunicação na Era Global, p. 16.

14 Ibid., p. 17.
} 
O comércio da cultura, organizado sob a ótica da rentabilidade, oferta um número limitado de "produtos", apoiados por enormes campanhas midiáticas, em detrimento da criatividade e das diversidades de conteúdos. Dessa maneira, a globalização que tenta impor unificação de sentidos, pode representar um desafio aberto para se questionar o seu autoritarismo sobre as múltiplas produções culturais das comunidades, por meio da expressão da comunicação alternativa. A expressão da comunicação alternativa é o do interesse público, de grupos, movimentos, de lugares, dos negros, das mulheres, dos gays, das associações de bairro, das favelas e de outros segmentos.

Nos estudos de John D.H. Downing ${ }^{15}$, identificam-se diversas formas de comunicação alternativa ou de grupos, denominadas por ele de mídias radicais:

- $\quad$ Os grafites, que são intervenções nos espaços públicos que incitam ou nutrem movimentos sociais.

- O vestuário é também muito expressivo enquanto mídia alternativa e pode ser contra-hegemônico, ou contra os padrões das grifes ou de moda comercial.

- $\quad$ Filme e vídeo. O preço das câmeras e equipamento se tornou mais acessível à mídia visual, os filmes e vídeos passaram a ser produzidos como produções independentes. Seus temas são sempre voltados para os assuntos dos excluídos e das minorias. Há também os filmes de arte, documentários, dirigidos para um público seleto de intelectuais, estudantes, estudiosos de arte, etc.

- Internet Radical apropriada pelos movimentos políticos, sociais, trabalhadores, minorias, de todo o mundo. Apresenta possibilidade de resistência aos poderes instituídos.

- $\quad$ O teatro popular e de rua são também tipos de comunicação alternativa, uma expressão rebelde, contra a hipocrisia das classes médias. Seu discurso é mais uma vez o discurso público e o corpo, como a dança, efeitos cênicos, linguagem irônica e satírica. No Brasil, Augusto Boal foi o primeiro a estimular essa comunicação; escreveu Teatro do Oprimido, inspirado na obra de Paulo Freire, A Pedagogia do Oprimido.

- A imprensa por meio de jornais de comunidades, imprensa trabalhista, jornais de pequenos partidos, com linguagem própria servem para integrar os membros da comunidade com informações, ofertas de emprego, notícias de aniversário, de falecimentos, quem chegou, quem partiu, reivindicações por infra-estruturas, etc.

\footnotetext{
${ }^{15}$ Midia Radical - Rebeldia nas Comunicações e Movimentos Sociais, p. 173-199.
} 
Mas entre todas as formas de comunicação alternativa, é o rádio que vem demonstrando ser portador de uma "espécie de força aglutinante das massas e caixa de ressonância para vozes e idéias", como diz Arlindo Machado $^{16}$.

É neste quadro que se considerará a rádio comunitária, amalgamada na história de seu povo, na intensa vida cotidiana de uma comunidade, onde povoam seus mitos, ritos, entes mágicos, sabores, ritmos e tantos outros valores expressivos da sua riqueza, materializados no seu cancioneiro, nas suas festas sagradas e profanas, nas suas formas de expressões, como se busca na relação da Rádio Paraitinga com a comunidade luizense, o objeto deste trabalho.

\subsection{As possibilidades alternativas da radiodifusão}

A história da utilização do rádio como mídia alternativa em relação aos processos hegemônicos da comunicação reveste-se de singular importância a partir da década de 80 , pois os avanços tecnológicos da radiodifusão contaram com a vantagem, em relação a outros meios de comunicação, de ser oferecida a custos baixos para a instalação de uma emissora, segundo John D.H. Downing $^{17}$. Soma-se a isto a acessibilidade para a aquisição de aparelhos baratos, como os micro-rádios originários da indústria oriental, notadamente a do Japão, da Coréia e da Tailândia, fator expressivo para potencializar o rádio como meio de comunicação alternativo.

A possibilidade de carregar o rádio para qualquer lugar estabelecendo uma relação de parceria e cumplicidade com o ouvinte e o barateamento do custo dos aparelhos tornou o veículo mais popular. Ainda hoje, o rádio continua a ser o veículo mais rápido e objetivo, levando entretenimento, formando opinião, chegando aos ouvintes de forma íntima e informal, é um verdadeiro termômetro do sentimento popular.

\footnotetext{
16 Texto de Introdução. In Mídia Radical - Rebeldia nas Comunicações e Movimentos Sociais, p.14.

17 Mídia Radical - Rebeldia nas Comunicações e Movimentos Sociais, p. 243.
} 
Com estas características somadas ao baixo custo de produção e distribuição, o rádio pode focar temáticas de interesse local, interpretando o mundo através de perspectivas e idiomas locais. A penetrabilidade, a natureza local e a capacidade de envolver comunidades num processo interativo de comunicação são qualidades imprescindíveis para justificar o poder do rádio no processo cultural.

Na última década, o rádio ganhou mais um aliado tecnológico ampliando suas possibilidades alternativas: com uma conexão única à Internet, a estação de rádio pode atuar como um portal para a riqueza de informação e recursos disponíveis, agregando também valor à própria informação, ao interpretá-la com os olhos da comunidade local, que a emite numa linguagem local, numa plataforma de retro-alimentação através da discussão local e das redes locais.

O crescimento considerável das webrádios por todo o mundo pode ser atribuído à facilidade dos programas de computador que permitem a captura de programas de rádio via Internet em tempo real. Este sistema de áudio contínuo permitiu mais agilidade, facilitando a audição de uma emissora ao vivo. Além disso, a interação com o público torna-se mais fácil: ao contrário das rádios convencionais em que o contato é efetuado unicamente por telefone, a webrádio permite a fácil e cômoda participação do público por e-mail, chat, fóruns e grupos de discussão. Além disso, o público pode pedir informações e se comunicar com especialistas.

No ambiente da rede, o conceito de ouvinte é substituído pelo de usuário, na medida em que os internautas, não se limitando a ouvir passivamente a informação tendem a interagir personalizando e ordenando o produto disponibilizado em função das suas preferências e optar quanto ao que querem ouvir e quando o pretendem fazer (e refazer...). O usuário toma o lugar do simples ouvinte, tornando-se uma parte indispensável do processo. A própria programação da emissora é crescentemente influenciada pelos usuários. A interação entre rádio e Internet potencializa ferramentas de custo relativamente baixo e poder indiscutível para o desenvolvimento econômicosocial ao permitir a comunicação do local para o global. 
Desta forma, as idéias de Bertold Brecht, em seu livro Teorias do Rádio, de 1927, em que o autor percebe a importância do rádio e suas potencialidades transformadoras, reassumem a contemporaneidade, ressignificadas pelo avanço da tecnologia, possibilitando uma nova leitura de seus pressupostos. Brecht também pensou a questão da música e sua inserção na linguagem radiofônica, ao mesmo tempo em que enfatizou a necessidade de mudança do comportamento do ouvinte. Essas preocupações estão claras quando ele comenta a experiência da sua radiopeça $O$ vôo transoceânico:

\footnotetext{
"O vôo transoceânico não pode servir à radiodifusão atual no sentido de modificá-la. A concentração dos meios mecânicos, assim como a especialização crescente da educação - processo que deve ser ativado - requer uma espécie de rebelião por parte do ouvinte, sua ativação e sua reabilitação como produtor" ${ }^{18}$
}

Na concepção de Brecht, o rádio deveria ser um meio de comunicação com duas mãos de direção, além do seu papel educativo e, sobretudo, político:

"Há que se transformar o rádio, convertendo o aparato de distribuição em aparato de comunicação. O rádio seria o mais fabuloso aparato de comunicação imaginável da vida pública, um sistema de canalização fantástico, se em vez de apenas transmitir pudesse também receber; quer dizer, o ouvinte não deve apenas ouvir, mas o rádio deveria fazê-lo falar. A radiodifusão deveria, em conseqüência, afastar-se dos que a abastecem e aproximar-se dos ouvintes que a abasteceriam."19

Para o estudioso e também dramaturgo Brecht, o rádio oferecia uma nova forma de pensar a dramaturgia, pois poderia organizar-se uma colaboração entre organismos teatrais e radiofônicos, por meio de atividades didáticas que trariam para o rádio inúmeras experiências de participação do ouvinte, dando-lhe a oportunidade de expressar-se sobre os seus sentimentos, suas esperanças e suas emoções diante do drama épico, da mesma forma como poderia dar a conhecer publicamente as decisões e produções do público, o resultado de atos coletivos tipo meeting com peças instrutivas ${ }^{20}$.

Walter Benjamin também participou desses debates, não apenas no plano teórico: o filósofo e pensador desenvolveu uma prática radiofônica que é pouco conhecida. Para pensar o rádio, Walter Benjamin partiu das técnicas de

\footnotetext{
${ }^{18}$ Bertold BRECHT, Teorias de la Radio - sugerencias a los directores artisticos de la radio, p.86.

${ }_{20}^{19}$ Ibid., p.86.

20 Ibid., p.89.
} 
registro e reprodução do som, surgidas no final do século XIX e do conceito de representação.

Com ela (a reprodução técnica do som), a representação da técnica atingiu tal padrão de qualidade que ela não somente podia transformar em seus objetos a totalidade das obras de arte tradicionais, submetendo-as a transformações profundas, como conquistar para si um lugar próprio entre os procedimentos artísticos. ${ }^{21}$

Embora o pensador alemão dedique esse ensaio ao universo da fotografia e do cinema, tais colocações se aplicam ao rádio, meio de comunicação em que atuou de maneira bastante intensa. De 1927 a 1933, Walter Benjamin teve uma atuação quase sistemática no rádio. Iniciava boa parte dos seus comentários radiofônicos com uma pergunta ou um fato cotidiano da vida alemã e, a partir dessas colocações, ele desenvolvia toda uma linha de pensamento a respeito das principais questões culturais que o afligiam. No rádio, Walter Benjamin uniu teoria e prática, participando das transformações que os novos meios de comunicação trouxeram ao papel de pensadores e artistas, logo que chegaram às massas.

A Alemanha vivia um período de intensa luta política. O movimento operário, embora dividido, ameaçava a ordem vigente. Nesse contexto o rádio passou a ser utilizado também como arma política, e Benjamin respondeu a esse desafio representado pelos novos meios com uma visão integradora das tarefas de escritor e jornalista. Isto faz parte do perfil de toda uma geração de autores que desmistificou o conceito de literatura, pondo-a em contato com o cotidiano prosaico.

Desde o início, Benjamin esteve ligado a revistas de programação radiofônica e, em março de 1927, ele realizou o seu primeiro programa diante do microfone. Seus contatos com o meio se intensificaram, tanto assim que, em 1930, o trabalho para o rádio chegou a ser a sua atividade principal. Como

\footnotetext{
${ }^{21}$ Walter BENJAMIN, A obra de arte na época da sua reprodutividade técnica, p.167.
} 
autor, crítico, moderador, locutor e produtor de emissões radiofônicas, Benjamin, entre 1927 e 1933, esteve presente em mais de oitenta programas, como diz Willi Bolle ${ }^{22}$, estudioso das obras de Benjamin.

Benjamin foi um dos primeiros a pensar o rádio como mediador cultural, além de instrumento de democratização da sociedade.

"O rádio - eis uma das conseqüências mais notáveis - revolucionou esse estado de coisas. Em virtude da possibilidade técnica inaugurada por ele, de dirigir-se na mesma hora a massas ilimitadas de pessoas, a popularização ultrapassou o caráter da intenção filantrópica e se tornou uma tarefa com leis próprias de essência e de forma, que se diferencia dos métodos tradicionais de modo tão nítido com a moderna técnica publicitária das tentativas do século passado." ${ }^{23}$

Benjamin defendia que antes do surgimento do rádio, quase não se conheciam meios de divulgação que fossem propriamente populares ou que correspondessem a finalidades de educação popular. Existia o livro, existia a palestra, existia o periódico: todos, no entanto, eram formas de comunicação que não se distinguiam em nada daquelas através das quais a pesquisa científica transmitia seus progressos para os especialistas.

Estas concepções de Brecht e de Benjamin alinham-se, na atualidade, com as aspirações de movimentos populares constituídas com objetivos específicos de promover a conscientização, a organização e a ação de segmentos de classes populares visando "satisfazer seus interesses e necessidades, como os de melhorar o nível de vida, através do acesso às condições de produção e de consumo de bens de uso coletivo e individual; promover o desenvolvimento educativo-cultural da pessoa", como diz Cicília Peruzzo ${ }^{24}$.

A essas preocupações soma-se a possibilidade de se contribuir para a preservação ou recuperação do meio-ambiente, assunto em pauta das necessidades vitais contemporâneas. Sobretudo esses movimentos reivindicam o exercício de seus direitos de participação política na sociedade e

\footnotetext{
${ }_{22}^{2}$ Fisiognomia da metropole moderna, p. 245.

${ }^{23}$ Walter BENJAMIN, Dois tipos de popularidade, p. 85.

${ }^{24}$ Cicilia M. K. PERUZZO, Direito à Comunicação Comunitária, participação popular e cidadania, p.20.
} 
consequentemente, o direito à cidadania. Esses movimentos, no processo de sua constituição, descobriram a necessidade de apropriação pública de técnicas e de tecnologias de comunicação, instrumentos para a transmissão e recepção de conteúdos para poderem se fortalecer e realizar seus objetivos, como diz Peruzzo 25 .

Desta forma, a comunicação se torna uma necessidade, ou seja, canais importantes para se comunicarem entre si e com seus públicos, sejam eles os usuários reais ou potenciais dos serviços oferecidos, a imprensa, os órgãos públicos, aliados no conjunto da sociedade, configurando a comunicação comunitária, que se expande para as atividades do homem inserido no seu cotidiano, espaço de conflitos, de debates, com necessidades próprias e que em que seu imaginário tem história, tem raízes, tem passado e projeções para o futuro.

Desta maneira, e por suas características acima apresentadas, o rádio torna-se um aliado importante para se colocar a serviço dos interesses populares, pois se realiza como parte de uma dinâmica de organização e mobilização social.

\subsubsection{Por uma teoria de rádio comunitária}

A rádio comunitária pode ser considerada como um processo alternativo, configurando-se, quase sempre, como possibilidade de mudança e subversão dos distintos elementos que compõem o processo comunicativo. $O$ alternativo em comunicação não tem uma definição estável, nem pode ter porque seu próprio desenvolvimento está ligado a um processo de mudança.

Uma comunicação poderá ser mais ou menos alternativa à medida que subverta uma ordem moral, política, social, econômica, tecnológica, cultural,

\footnotetext{
${ }^{25}$ Cicilia M. K. PERUZZO, Direito à Comunicação Comunitária, participação popular e cidadania, p.20.
} 
simbólica e ideológica. Trata-se de um termo aberto, nunca fechado. No entanto, há experiências deste segmento da comunicação sistematizadas em estudos acadêmicos, publicações ancoradas em suportes teóricometodológicos e recorrentes em objetos de pesquisa, podendo-se inferir, que, a rádio comunitária, mesmo estando na busca por uma definição, já incorpora conceitos que delimitam suas características.

Para tratar-se da rádio comunitária são necessárias algumas considerações sobre a mídia comunitária, que se apresenta de forma muito clara em suas configurações quanto aos conteúdos e quanto às formas de produção e processos de gestão.

Como apresenta Peruzzo ${ }^{26}$, algumas de suas configurações se misturam com outros tipos de mídia, especialmente a local, que por sua vez, podem apresentar pontos comuns com a comunitária, o que acaba por gerar dificuldades de compreensão e de diferenciação entre os dois processos: comunitário e local.

Para a autora, estas dificuldades são geradas por três fatores: a) a impossibilidade de delimitar os objetos comunitário e local em fronteiras bem demarcadas, não só territoriais como também entre os espaços comunitário, local e regional; b) a impossibilidade de separar as práticas comunicativas, seus conteúdos e simbologias por tipo de comunicação, e c) a apropriação e o uso do termo comunitário para denominar programas ou emissoras de forma indiscriminada por diferentes tipos de mídia.

Assim, a comunicação comunitária e local não é algo exterior aos processos sociais concretos, mas são partes constitutivas e constituintes da dinâmica social. No Brasil, onde se começa a lidar com os meios de comunicação de baixa potência ou de pequena circulação, parece que o local se caracteriza como um espaço determinado, um lugar específico de uma região, no qual a pessoa se sente inserida e partilha sentidos. Este é um

${ }^{26}$ Cicilia M. K. PERUZZO, Mídia local e suas interfaces com a mídia comunitária, p.52. 
espaço familiar, direto, muito embora as demarcações territoriais não lhe sejam determinantes.

Defende Peruzzo que o local indica possuir dimensões de proximidade e de familiaridade, porém, ele não permite ser tomado com contornos territoriais precisos, pelo menos não como conceito universal, o qual pode ser válido para realidades específicas, mas não necessariamente como regra geral, especialmente na ótica dos meios de comunicação que, com os avanços tecnológicos, podem se deslocar do local ao universal num mesmo processo comunicativo.

Desse modo, para a autora, os elos de proximidade e de familiaridade ocorrem muito mais pelos laços de identidades de interesses e simbólicos, do que por razões territoriais, mesmo que a questão geográfica seja fator importante na configuração da localidade.

Embora as demarcações geográficas possam ajudar a configurar o local em relação à cobertura e aos efeitos das mídias, elas são imensuráveis, pois somam-se às demais singularidades, identidades e diversidades sócioculturais, históricas, ecológicas, de comunicabilidade etc., que ajudam a construir o espaço local ou comunitário. Neste sentido, não se pode desprezar o território geográfico enquanto fonte de significados, pois ele faz parte das condições objetivas e concretas da vida, como o tipo de solo, de clima, das tradições, de língua, dialetos, sotaques e outros elementos.

É possível compreender que a separação entre as dimensões comunitária e local é impraticável do ponto de vista objetivo, mas pode-se, no entanto, apontar suas características singulares. A comunidade se situa dentro de um espaço local, e o espaço local é sempre mais amplo e diversificado que uma comunidade. Os vínculos tendem a ser mais estreitos no espaço comunitário do que em nível local.

Existe comunidade dentro de um espaço local quando alguns de seus segmentos sociais existentes apresentam graus e formas de organização 
típicas de uma comunidade, tais como laços de cooperação entre os indivíduos, sentimento de pertencimento, interação, participação ativa dos membros na construção de interesses comuns. As relações sociais entre aqueles que vivem ou participam do cotidiano, no espaço local tendem a ser mais heterogêneas do que em comunidades. Para Peruzzo, não existem padrões universais de classificação do sujeito local; cada espaço local é diferente do outro, tem suas características e diversidades. O mesmo vale para a comunidade, onde cada uma só pode ser compreendida em suas especificidades.

Comunidade, completa a autora, não pode ser confundida com bairro, cidade ou com segmentos étnicos, religiosos etc., porque ela pressupõe a existência de elos mais profundos do fenômeno comunitário. A comunidade tem características que vêm sendo mantidas no tempo: sentimento de pertença, participação, interação, objetivos comuns, interesses coletivos, acima dos individuais, identidades, cooperação, cultura comum etc.

Nesse sentido, o processo dos movimentos populares no Brasil, desde 1980, vem legitimando o comunitário como uma prática social em que se desenvolvem aptidões associativas para superar os problemas dos segmentos sociais fragilizados, de ampliar o exercício da cidadania, numa interação baseada na proximidade, não só de lugar, mas acima de tudo, de interesses e identidades.

Desta forma, não basta falar de coisas do lugar para que um meio possa ser considerado comunitário; o que mais importa são as identidades, o vínculo e a inserção como parte de um processo comunitário mais amplo compromissado com a realidade concreta de cada lugar. Assim, podem-se comparar algumas das características principais da mídia comunitária com as da mídia local. 


\section{Peruzzo $^{27}$ elenca as características próprias de cada uma delas, a}

saber:

- $\quad$ "a mídia comunitária se realiza com base em processos nos quais as pessoas da comunidade sejam as protagonistas;

- tem como objetivo divulgar assuntos específicos das comunidades, de movimentos coletivos e de segmentos populacionais ou de interesses públicos, que normalmente não encontram espaços na mídia convencional;

- o receptor pode se tornar emissor e vice-versa; quem produz as mensagens pode ser o cidadão comum;

- ter a meta de contribuir para o desenvolvimento comunitário;

- não ter finalidade lucrativa;

- os conteúdos dizem respeito às necessidades, artes, cultura e problemas de interesse local;

- gestão coletiva;

- $\quad$ propriedade coletiva, individual ou institucional, a serviço da comunidade;

- $\quad$ autonomia em relação ao poder público;

- alcance limitado em termos de cobertura e audiência, número de leitores".

Por sua vez, a mídia local se caracteriza por reproduzir a lógica dos grandes meios de comunicação, em especial ao que se refere ao sistema de gestão. Mas, se diferencia quanto ao conteúdo dando mais destaque às especificidades de cada região, enquanto que a grande mídia utiliza assuntos que interessam a um maior número de pessoas possível, o que a conduz para temas de interesse nacional e internacional. Outras características são:

- "é uma unidade de negócio comercial, de interesses mercadológicos;

- pode corresponder a interesses políticos e econômicos de empresas, políticos, lideranças etc.;

- explora o local como nicho de mercado, pelo qual os temas da localidade interessam enquanto estratégia para aumentar a lucratividade;

- submetem os espaços abertos à participação dos cidadãos ao controle dos dirigentes;

- a programação é produzida por especialistas;

- gestão burocrática tradicional;

- os conteúdos tendem a ser parte daqueles tratados pela grande mídia, mas com enfoque local ou regional".

Diante destes pressupostos, a rádio comunitária configura-se teoricamente por:

${ }^{27}$ Cicilia M. K. PERUZZO, Mídia local e suas interfaces com a mídia comunitária, p.57-60. 
"A rádio comunitária é uma emissora de radiodifusão sonora de alcance local, que funciona em baixa potência (abaixo dos $250 \mathrm{w}$ ), em FM (freqüência modulada). Sua organização se dá por uma associação sem fins lucrativos, de programação plural, de gestão pública, de filiação aberta a toda a comunidade, independente de raça e etnia, credo, classe social, orientação sexual, opção política, idade. É administrada por uma identidade que poderá denominar-se 'Rádio Clube', ou associação que conte em sua estrutura com Diretoria Executiva, Conselho de Entidades, Conselho Fiscal e Conselho de Programação e suas deliberações sejam tomadas em Assembléias Gerais de filiados (as)". ${ }^{28}$

É da natureza da rádio comunitária promover a ampliação do acesso à informação, prestar serviços de utilidade pública, promover a cultura e o lazer para as comunidades.

A rádio comunitária contribui para a satisfação das necessidades da comunidade e para o seu desenvolvimento de uma forma progressiva, promovendo as mudanças sociais e a democratização da comunicação através da participação da comunidade, segundo Lopez Vigil. ${ }^{29}$ Promove a cultura da paz, a democracia, os direitos humanos, a eqüidade da comunidade onde se localiza, favorecendo o desenvolvimento cultural e socioeconômico da comunidade.

É necessário que a rádio comunitária tenha autonomia, que expresse a pluralidade de opiniões da comunidade, que pertença a várias entidades ou associações da comunidade, que seja administrada pela comunidade.

Desta forma, na rádio comunitária, produtores e receptores, costumam ser os mesmos sujeitos sociais, substituindo-se os termos público, espectador e leitor, pela idéia muito mais estimulante de audiência ativa, partindo do pressuposto de que as formas alternativas de mídia dão expressão mais avançada da cultura popular, contando com um público que elabora os seus produtos, em lugar de apenas receber passivamente, como defende Downing. ${ }^{30}$

\footnotetext{
${ }^{28}$ www.cemina.org , acesso 12/07/2006

29 Lopez VIGIL, Manual Urgente para Radialistas Apaixonados, acesso por http://comunica.org.apasionados/pdf/radioapasionados/pdf em 14/09/2006

30 John D.H. DOWNING, Mídia Radical - Rebeldia nas Comunicações e Movimentos Sociais, p. 38.
} 
Nas rádios comunitárias debatem-se diferentes temas, respeitando-se sempre a diversidade cultural, e não se tolerando qualquer tipo de ditadura, nem mesmo a musical dos grandes estúdios de produção e gravação. Defende Lopez Vigil que as rádios comunitárias se definem pelas seguintes características: não têm fins lucrativos; a comunidade detém o controle e propriedade da rádio; a participação da comunidade é central neste processo.

O autor defende que rádios comunitárias não têm por objetivo fazer algo para as comunidades: a própria comunidade deverá fazer algo para si mesma, controlando os seus meios de comunicação. As rádios comunitárias têm objetivos de mudança social, promovendo o direito à comunicação e à informação, numa perspectiva de um sistema justo que tenha em consideração direitos humanos, tornando o poder acessível às pessoas e abrindo-o à sua participação.

Não obstante todos os pressupostos centrais que baseiam a configuração de uma rádio comunitária, ela é também um espaço de conflitos. Não existe um modelo único, e cada vez mais vai se revelando uma pluralidade de formas e mostrando sua validade no contexto das comunidades, mesmo que não expressem mecanismos puros de autogestão. Existem emissoras de matizes diferentes sob o rótulo de comunitária, como observa Peruzzo:

..."algumas são operadas como negócio comercial; outras são
religiosas; outras estão a serviço de políticos profissionais; há também
aquelas operadas por entusiastas do rádio e do trabalho comunitário,
mas que acabam por desenvolver o personalismo de suas lideranças,
dificultando o envolvimento da população; mas existem também
aquelas de caráter público vinculadas a organização comunitária e a
movimentos sociais. É campo de conflito também por que não são bem
aceitas por todos os segmentos da sociedade. Há quem as considere
"piratas", causadoras de quedas de aviões. Os conflitos também
afloram nas disputas internas, nas disputas entre opositores e entre as
classes sociais". ${ }^{11}$

Porém, os conflitos e as contradições são inerentes às sociedades, e não devem anular o mérito desse tipo de ação cidadã, porque, com elas, a sociedade abre-se para múltiplas experiências. A ampliação de números de emissoras abre mais vias para a democratização da comunicação e da cidadania.

${ }^{31}$ Cicilia M. K. PERUZZO, Direito à Comunicação Comunitária, participação popular e cidadania, p.23. 
Mesmo uma rádio de baixa potência comercial apresenta pontos positivos por estar contribuindo, de certa forma, para a comunicação cidadã, forçando a democratização do acesso a canais, contestando o sistema de controle da mídia, representada pelos oligopólios dos grandes meios de comunicação de massa no Brasil, conclui a autora.

\subsubsection{A rádio comunitária no Brasil}

A expressão rádio comunitária foi criada no Brasil por algumas entidades privadas, filantrópicas, sem fins lucrativos, culturais ou com finalidade educativa, no fim da primeira metade da década de 90. Estas rádios eram regularmente registradas em cartório, atentas às necessidades de comunicação de que careciam as comunidades municipais, e que não dispunham de serviço de radiodifusão, ainda inconformadas com o fato de o governo federal não Ihes deferir autorização para operarem em pequena potência e alcance limitado, em nível local, iniciaram um movimento de instalar esse tipo de estação, enquanto aguardavam a devida autorização do governo, de acordo com Paulo Fernando Silveira ${ }^{32}$.

Em outros países, a expressão rádio clandestina tem origem na Primeira Guerra Mundial, quando através de estações ocultas, fazia-se difusão de programação para conscientização do povo. Estas rádios só existem em regimes de governo de dominação e é próprio deles, onde o povo é submetido ao controle do Estado.

Durante a segunda Guerra Mundial, surgiram na França inúmeras rádios clandestinas para apoiar a resistência contra os alemães, afirma Silveira ${ }^{33}$. As rádios piratas foram assim chamadas na Inglaterra, na década de 60, para os jovens irradiarem suas idéias de liberdade, como os hippies. Transmitiam a partir de navios fundeados em oceanos, fora do alcance de controle do Estado.

\footnotetext{
${ }^{32}$ Rádios Comunitárias, p. 4 . O autor é juiz de Direito e atuou entre os juizes de direito em defesa das autorizações, desde 1995, já que o governo não se dispunha a atender, de forma regular e em prazo razoável os milhares de pedidos que foram encaminhados ao Ministério das Comunicações.

${ }^{33}$ Ibid., p.4.
} 
Já as rádios livres são aquelas que correspondem como modelo alternativo ao oficial e surgiram na Inglaterra em substituição às piratas.

Portanto, o que se extrai é que onde há democracia plena, com o Estado funcionando instrumentalmente ao administrar os serviços de telecomunicações, sem interferir na livre manifestação do pensamento, não emergem as estações chamadas de alternativas, piratas ou clandestinas.

Contrariamente, sempre que o Estado, ignorando os direitos individuais fundamentais que funcionam como pilares da democracia e esquecendo sua formatação em preceitos constitucionais, ostentando sua natureza ditatorial e totalitária, no qual ele expressa seu domínio político, faz suscitar as rádios livres, como veículos da liberdade, da democracia e da cidadania, diz Silveira ${ }^{34}$.

Para Peruzzo ${ }^{35}$, a expansão das rádios comunitárias é o resultado de um processo de mobilização social pela regulamentação da radiodifusão de baixa potência cujo marco histórico é o dia 10 de abril de 1995, quando o então Ministro das Comunicações, Sérgio Motta, recebeu um grupo de representantes das rádios livres e comunitárias, ocasião em que reconheceu a existência de milhares de emissoras de baixa potência em todo o país, assumindo o compromisso de regulamentar o seu funcionamento.

Em 1996, foi criada a ABRAÇO - Associação Brasileira de Rádios Comunitárias para organizar e representar as emissoras de baixa potência. Juntamente com o Fórum Nacional pela Democratização da Comunicação, passam a organizar encontros sobre radiodifusão livre e comunitária e contribuem para a elaboração das propostas de lei apresentadas ao Congresso Nacional para a legalização das emissoras comunitárias.

O Serviço de Radiodifusão Comunitária foi criado pela Lei 9.612 de 1998, regulamentada pelo Decreto 2.615 de 1998. Autoriza a operação de emissoras com, no máximo 25 Watts de potência e antena não superior a 30 metros, com cobertura restrita a um raio de $4 \mathrm{~km}$, a partir da antena. Autoriza apenas uma rádio em cada localidade, obrigando as emissoras a operarem em

\footnotetext{
${ }^{34}$ Paulo Fernando SILVEIRA, Rádios Comunitárias, p.3.

${ }^{35}$ Cicilia M. K. PERUZZO, Participação nas Rádios Comunitárias no Brasil, p. 5.
} 
freqüência FM no país todo. Proíbe a formação de redes, a propaganda, cabendo ao governo fazer a seleção ou a outorga de concessões, com a aprovação do Congresso Nacional.

Da programação diária de uma rádio comunitária deverão constar blocos de informação de lazer, manifestações culturais, artísticas folclóricas e outras que contribuam para o desenvolvimento da comunidade, sem discriminação de raça, religião, conviç̧ões político-partidárias e condições sociais. Uma rádio comunitária não pode utilizar a programação de qualquer outra emissora, salvo exista expressa determinação do Governo Federal.

Também não poderá incluir propaganda comercial, exceto sob a forma de apoio cultural, de estabelecimentos localizados na sua área de cobertura. Apenas associações e fundações comunitárias que tenham o objetivo de radiodifusão comunitária nos seus estatutos poderão prestar este serviço. "Através das rádios comunitárias é possível difundir idéias, elementos de cultura, tradições e hábitos sociais da comunidade e oferecer mecanismos de formação e integração da comunidade, estimulando o lazer, a cultura e o convívio social. Com as rádios comunitárias prestam-se ainda serviços de utilidade pública. Através deste veículo, a comunidade faz a sua própria comunicação informal, mas real, concretizando a liberdade de expressão". ${ }^{36}$

Muito embora a lei represente um avanço por regularizar o segmento de rádios comunitárias, os representantes dessas vêm detectando muitos limites e restrições que dificultam a atuação das emissoras. Onde há cerco de montanhas, o alcance ainda é restrito; impossibilita as emissoras na atuação conjunta em rede; proíbe a propaganda e, com isso, a única forma de patrocínio é por meio de apoio cultural, o que dificulta a obtenção de recursos; autoriza apenas uma emissora na localidade, quando as entidades reivindicam duas a doze para cada município.

O acesso à informação e aos canais de expressão é um direito de cidadania, fazendo parte dos direitos das pessoas, tal como os direitos políticos

\footnotetext{
${ }^{36}$ www.cemina.org acesso em 12/07/2006
} 
- participação no exercício do poder político, os sociais - participação, com igualdade, do nível de vida e do patrimônio social - e ao de liberdade de expressão de idéias, conviç̧ões, crenças etc., e ainda ao de deslocar-se da noção de direitos individuais para o coletivo: direito de grupos humanos, dos movimentos coletivos, e em suas diferenças. ${ }^{37}$

Neste sentido, a Declaração Universal sobre a Diversidade Cultural, aprovada pela Unesco, no dia 20 de outubro de 2005, representa um avanço na direção da democratização e direitos à cidadania para todas as localidades do mundo, atingidas pela ameaça da globalização cultural pelos oligopólios da comunicação.

A ABRAÇO estima que, atualmente, possam estar operando no Brasil cerca de 20 mil rádios de baixa potência, que tentam se estabelecer como rádio comunitária. Porém, nem todas podem estar cumprindo a missão que the é destinada, isto é, a de assumir o papel social pela comunidade e para a comunidade, tornando-se, muitas vezes, de caráter político ou religioso, com claros interesses individuais.

\subsubsection{Rádio Comunitária - uma demanda aos direitos à comunicação e à cidadania}

A rádio comunitária desempenha um papel muito importante na democratização da informação e na conquista pelo direito à cidadania, não só pela possibilidade de ampliação de instalação de emissoras, diversificando, desta forma, os emissores, mas, sobretudo por se constituir em processos comunicacionais de comunidades, garantindo uma contra-comunicação frente ao poder da grande mídia.

Para Peruzzo:

..."Entre as principais características desse processo comunicacional estão: opção política de colocar os meios de comunicação a serviço dos interesses populares; transmissão de conteúdos a partir de novas fontes de informações (do cidadão comum e de suas organizações

${ }^{37}$ Cicilia M. K. PERUZZO, Direito à comunicação comunitária, p.31. 
comunitárias); a comunicação é mais que meios e mensagens, pois se realiza como parte de uma dinâmica de organização e mobilização social; está imbuído de uma proposta de transformação social e, ao mesmo tempo, de construção de uma sociedade mais justa; abre a possibilidade para a participação ativa do cidadão comum como protagonista do processo". ${ }^{38}$

A concentração empresarial no setor da comunicação e a progressiva transformação da informação em mercadoria implicam numa negação dos direitos da comunicação: ameaça o direito à informação e à liberdade de expressão, à diversidade e à pluralidade midiáticas.

Esta situação convoca todos os setores comprometidos com a democracia a estarem vigilantes e a assumirem a necessidade de democratizar a comunicação, pois o ato de comunicar é tão antigo quanto a existência do homem. É graças à comunicação que o ser humano conseguiu desenvolver as formas mais complexas de interação e convivência.

A "Carta de Brasília - Encontro Nacional de Direitos Humanos -2005" de 18 de agosto de 2005, na Câmara dos Deputados declarou: considera-se que a comunicação é um direito humano que deve ser tratado no mesmo nível e grau de importância que os demais direitos humanos. ${ }^{39}$

Para os deputados, autores do referido documento, o direito humano à comunicação incorpora a inalienável e fundamental liberdade de expressão e o direito à informação, ao acesso pleno e às condições de sua produção, e avança para compreender a garantia de diversidade e pluralidade de meios e conteúdos, a garantia de acesso eqüitativo às tecnologias da informação e da comunicação, a socialização do conhecimento a partir de um regime equilibrado que expresse a diversidade cultural, racial e sexual; além da participação efetiva da sociedade na construção de políticas públicas, tais como conselhos de comunicação, conferências nacionais, regionais e locais.

Desta forma, concluem que a importância do direito humano à comunicação está ligada ao papel da comunicação na construção de

\footnotetext{
${ }^{38}$ Cicilia M. K. PERUZZO, Direito à comunicação comunitária, p.20.

39 http://www.crisbrasil.org.com/apc.aa/projetos.htm. acesso dia 27/07/2006
} 
identidades, subjetividades e do imaginário da população, bem como na conformação das relações de poder.

Peruzzo busca em Cees Hamelink alguns dos aspectos centrais relativos ao direito à comunicação, que foram elaborados em documento e apresentado por ocasião da preparação da CMSI - Conferência Mundial sobre a Sociedade da Informação, em 2002, a saber:

a) "Direitos de informação: consiste no direito à liberdade de pensamento, consciência e religião; direito de ter opinião, de expressar opinião sem interferência; direito de ser informado sobre temas de interesse público; direito de acesso a meios públicos de distribuição de informação, idéias e opiniões.

b) Direitos culturais: direito de promover e preservar a diversidade cultural; de participar livremente da vida cultural da comunidade; de praticar tradições culturais; de desfrutar das artes e do progresso científico; de proteção da propriedade e do patrimônio cultural nacional e internacional; direito à criatividade e independência artística, literária e acadêmica; direito de usar nosso idioma em ambiente público e privado; direitos das minorias e dos povos indígenas à educação e a estabelecer seus próprios meios de comunicação.

c) Direitos de proteção: direito das pessoas em ser protegidas da interferência em sua privacidade por meios de comunicação massiva ou agências públicas e privadas; proteção das comunicações privadas das pessoas; direito de respeitar a dinâmica de cada processo em forma de comunicação pública; direito de proteção contra formas de comunicação discriminatórias por raça, cor, sexo, idioma, religião ou origem social; direito de proteção contra a informação enganosa e distorcida; direito de proteção contra a propagação sistemática e intencional da crença que indivíduos ou grupos sociais merecem ser eliminados; direito de proteção da independência profissional dos empregados de agências de comunicação pública ou privadas frente a interferência dos donos e administradores dessas instituições.

d) Direitos coletivos: direito de acesso das comunidades à comunicação pública; direito ao desenvolvimento das infraestruturas de comunicação, à consecução de recursos adequados, à distribuição do conhecimento e habilidades, à igualdade de oportunidades econômicas e a correção das desigualdades; direito ao reconhecimento de que os recursos do conhecimento são um bem comum de propriedade coletiva; direito à proteção desses recursos de sua apropriação privada por parte das indústrias de conhecimento.

e) Direitos de participação: direito de adquirir as capacidades necessárias para participar plenamente da comunicação pública; direito das pessoas a participar na tomada de decisões públicas sobre o provimento de informação, à produção de cultura ou a produção e aplicação de conhecimento; direito das pessoas a 
participar na tomada de decisões públicas envolvidas na seleção, desenvolvimento e aplicação de tecnologias de comunicação".

Neste cenário, em que a mídia hegemônica ameaça as diversidades culturais, a inalienável e fundamental liberdade de expressão e o direito à informação, surgem (ou insurgem-se) demandas por cidadania, representadas por lideranças populares, de onde permeia a idéia de se formar conselhos ou comitês locais de comunicação.

Peruzzo desenha uma possibilidade de organização de um modelo de Comitê Local de Comunicação, que pode auxiliar as diversas rádios comunitárias na consecução de seus objetivos, por meio de diversas ações, que devem ser ajustadas às singularidades de seus interesses, tais como:

a) "Fazer um levantamento (diagnóstico) sobre quais são os meios de comunicação existentes na localidade e dentre eles quais seriam os mais adequados para servir como instrumento de comunicação local.

b) Diagnosticar quais são as necessidades locais em matéria de comunicação.

c) Contribuir para a formação de equipes de comunicação visando implementar sistemas de informação e comunicação comunitários, como por exemplo um boletim informativo, rádio comunitária, um sistema de alto-falantes, um programa de rádio para ser exibido em emissoras existentes etc.

d) Contribuir para a melhoria da performance de meios comunitários já constituídos.

e) Desenvolver mecanismos de mobilização e de incentivo à organização local para uso dos meios de comunicação comunitária.

f) Organizar cursos e oficinas de capacitação para o uso da comunicação (exemplo: jornal, expressão verbal, rádio, vídeo, cartaz, internet etc.).

g) Organizar treinamentos para elaboração de projetos de captação de recursos.

h) Ocupar espaços nos meios de comunicação locais (não só os comunitários) através de entrevistas, depoimentos, sugestões e até com programas próprios produzidos por alguma entidade popular ou equipes de comunicação da própria população;

${ }^{40}$ Cicília M. K. PERUZZO, Direito à comunicação, p.29-30. 
I) Divulgar as atividades das organizações comunitárias e contribuir para motivar as pessoas à participação na comunicação. ${ }^{41}$

${ }^{41}$ Cicília M. K. PERUZZO, Direito à comunicação, p.39. 


\section{CAPÍTULO 2}

Identidade cultural e a força de sua expressão

para a comunidade 


\section{Identidade cultural e a força de sua expressão para a comunidade}

"A alegria é sem pecado, sem perdão e sem submissão."

Muniz Sodré ${ }^{42}$

A rádio comunitária focaliza a participação ativa de indivíduos e de grupos sociais na construção ou ressignificação do sentido de sua cultura, de sua identidade e de sua memória, decorrente das práticas e das relações sociais, como foi visto no capítulo anterior. É nesta experiência cultural e comunicacional que intervêm os processos de interlocução e de interação que criam, alimentam e restabelecem os laços sociais e a sociabilidade entre os indivíduos e os grupos que partilham os mesmos quadros de experiência e que identificam as mesmas ressonâncias de um passado comum.

Nesta perspectiva, os processos culturais e comunicacionais geram um outro processo dentro do qual emergem a pluralidade da vida cotidiana que são fatores importantes na formação de indivíduos, na maneira em que se inscrevem no mundo, suas possibilidades, seu modo de perceber e dar sentido à vida.

Uma rádio comunitária deve ter como premissa a experiência concreta na elaboração dos sentidos sociais porque é a partir da objetividade cotidiana que se constroem e se definem os significados sociais.

As culturas populares, objetivamente experimentadas e cotidianamente vividas, expressam formas de se apropriar do mundo, de interpretá-lo criativamente e de percebê-lo no presente, valorizando o passado nele contido, projetando-o assim, para o futuro.

Existem processos em que os sentidos prevalecentes nem sempre correspondem ao pensamento hegemônico. Mesmo com o "pacto" ou o

${ }^{42}$ Muniz SODRÉ, As Estratégias Sensiveis - afeto, mídia e politica, p. 223. 
consenso entre os dominantes e os subalternos, existe a possibilidade de que a "negociação" encontre limites. Isto porque, na atribuição de sentidos, não se pode considerar o indivíduo refratário e indiferente às forças dos sentidos preexistentes, em que se encontram os referenciais para a construção de sua própria subjetividade, como defende Maria Luisa Mendonça. ${ }^{43}$

A "negociação" de sentidos, para a autora, são as experiências concretas da vida, em que o cotidiano, as percepções, as formas de interpretar e as expectativas nutridas estão, muitas vezes, em desconformidade com os valores hegemônicos.

É possível compreender a significação política do lugar e do cotidiano na construção da vida social ao reconhecê-los como espaço onde se situam as matrizes dos sentidos atribuídos à vida individual e à coletiva. ${ }^{44}$

O sujeito como agente político manifesta-se como propulsor da produção ativa da sociedade, nas formas populares ou subalternas, que pode existir mesmo sob o poder vertical da massificação da produção cultural, e também pode contribuir para a construção de indivíduos livres e autônomos. Nisto reside a capacidade das classes populares em produzir valores como a solidariedade, a integração, o compartilhamento e humanização, na medida em que os indivíduos não se satisfazem só com o consumo cultural dos meios massivos, reafirmando a sua vivência, autovalorização, dignidade e aspirações ao reconhecimento social.

Afirma a autora ser possível pensar na existência de espaços para a construção da subjetividade que se encontram fora do interesse, tanto das indústrias culturais quanto das instâncias oficiais da socialização. ${ }^{45}$ Nesses espaços, expressos pelo cotidiano e pelo lugar, emergem os atores sociais -

\footnotetext{
${ }^{43}$ Revista Novos Olhares, Comunicação e Cultura, p. 35.

${ }^{44}$ Ibid., p. 35 e 36.

45 Ibid., p. 37.
} 
agentes transformadores, que, por meio de seu patrimônio cultural, promovem a união, a interação social e a afirmação de sua existência.

No cotidiano e no lugar pode-se identificar a dimensão política a partir da compreensão da produção cultural e das formas primárias de construção dos sentidos. Dessa maneira, abre-se a possibilidade para se propor ações concretas que possam dinamizar e incentivar o surgimento de sujeitos atores sociais.

A rádio comunitária, os partidos políticos, os sindicatos, as associações sociais e os diversos tipos de organizações operam de uma maneira mais objetiva na formação de sujeitos - atores sociais. Mas, como afirma Mendonça, os elementos culturais estão sempre presentes em todas as situações, permeando todas as experiências e são necessários para atribuir significado à vida.

\subsection{Cultura e identidade cultural}

Um povo, uma comunidade são possuidores de uma identidade, ou seja, hábitos, costumes, valores que são comuns aos seus membros e os diferenciam de outros povos ou comunidades.

Cultura então pode ser conceituada, num sentido mais amplo, como o modo de vida de uma dada população. Também é um conceito que diz respeito a uma base territorial, identificando-se por um modo de vida próprio no qual um povo desenvolve uma religião, um modo de fazer política, uma língua.

É o conjunto de características que formam a identidade de um povo e essa identidade distingue seus membros.

Há componentes de distinção de uma cultura de âmbito interno, ou seja criados pelo próprio grupo e outros de âmbito externo, importados de outras 
culturas, este último denominado aculturação. Assim, não se pode esquecer que "a construção da identidade nacional deve considerar que os limites da cultura não coincidem com os do Estado, visto que a aculturação sempre está presente e implica aberturas e interpenetração específicas. Além disso, cultura é uma autocriação, negociação de sentidos." 46

Outro elemento importante é a memória coletiva, possível quando um povo guarda suas características, seus valores. Há povos que mantêm a memória coletiva através das tradições, mantidas há gerações, garantindo dessa forma sua identidade. É o que acontece, por exemplo, com as culturas japonesa e judaica. A luta pela manutenção da base territorial quase sempre está presente; no entanto, a cultura judaica, mesmo perdendo a base territorial, mantém sua cultura junto aos seus descendentes.

Não há conceito mais dificil de se definir do que o de cultura, dificuldade que resulta não da falta de definições, mas do excesso. Todos os campos das humanidades, da filosofia às ciências sociais, da filologia à antropologia, e esta especialmente, possuem definições específicas de cultura, adaptadas à delimitação das fronteiras do conhecimento que cada um desses campos recobre.

Revisitando alguns estudiosos, destacam-se aqueles que podem responder ao universo conceitual ao qual o objeto desta pesquisa se insere, isto é, no campo da cultura e da comunicação, marcado pelo processo da globalização, que podem por em risco as diversidades e identidades culturais. Os conceitos de tradição e de renovação são elementos que permeiam a busca de uma resposta à atuação das rádios comunitárias, com um projeto de humanização do homem, em que o imáginário tem história, tem raízes, tem passado e projeções para o futuro, fundados no direito ao acesso à comunicação.

A palavra "cultura" decorre de metáforas - cultivar, criar, alimentar processos orgânicos que já possuem conotação bastante diferente no cotidiano

\footnotetext{
${ }^{46}$ Boaventura de S. SANTOS, Pela Mão de Alice - o social e o político na pós-modernidade, p. 148.
} 
da civilização industrial. Os processos orgânicos implicam naturalidade e integração, ao passo que a modernidade diz respeito à alienação, ao mecanismo e à divisão analítica e social.

Cultura, nessa concepção, pressupõe uma relação com a natureza, tendo como objeto o artesanato e um baixo nível de divisão do trabalho. Implica a comunicação direta e pessoal num ambiente social onde o indivíduo não é somente um na massa, mas possui uma identidade. Nessa sociedade os ideais de cultura estão vinculados às celebrações de nação e etnia, nas quais a língua, as tradições e o caráter nacional dão autenticidade à comunidade. Esses ideais são transmitidos de geração a geração caracterizando e identificando aquele povo.

A cultura popular é muitas vezes confundida com folclore, no entanto a cultura popular, como folclore, recupera invariavelmente a idéia de "tradição", seja na forma de tradição-sobrevivência, seja na perspectiva de memória coletiva que age dinamicamente no mundo da práxis. "Esta ênfase no caráter tradicional do patrimônio popular implica, na maioria das vezes, uma posição conservadora diante da ordem estabelecida." 47

Florestan Fernandes aponta este caráter conservador ao considerar o folclore como uma necessidade histórica da burguesia européia. Para o autor, definir a cultura popular como o saber tradicional das classes subalternas das nações civilizadas, implicaria imediatamente assimilá-lo à dimensão de atraso, de "retardatário". Tal concepção legitimaria a existência de uma dicotomia estrutural da sociedade; por um lado teríamos uma elite que se consolidaria como fonte e promulgadora do "progresso", por outro, as classes subalternas, que representariam a permanência de formas culturais que arqueologicamente se acumulariam como legado de um passado longínquo.

Pela conceituação de Florestan Fernandes, pode-se inferir que seria legítimo perguntar se ela não se restringiria aos limites das sociedades européias; no caso do Brasil, pensamos que o folclore é menos uma

\footnotetext{
${ }^{47}$ Florestan FERNANDES, Sobre o Folclore, in O folclore em Questão, p. 38-48.
} 
necessidade da burguesia, mas, sobretudo uma forma de saber que se associa, de início, às tradicionais de origem agrária.

De qualquer maneira persiste o elemento conservador; valoriza-se a tradição como presença do passado, todo "progresso" implicando um processo de dessacralização da sabedoria popular. Rompe-se, dessa forma, a identidade forjada entre folclore e cultura popular. $E$, enquanto folclore é interpretado como sendo as manifestações culturais de cunho tradicional, a noção de cultura popular é definida em termos exclusivos de transformação. Essa posição tem trazido ao folclorista críticas que o tomam por detentor de uma atitude de paternalismo cultural.

O conceito de cultura popular se confunde com a idéia de conscientização; subverte-se desta forma o antigo significado que assimilava a tradição à categoria de cultura popular. "Cultura popular" não é, pois, uma concepção de mundo das classes subalternas, como o é para certos folcloristas que se interessam pela "mentalidade do povo", nem sequer os produtos artísticos elaborados pelas camadas populares, mas um projeto político que utiliza a cultura com elemento de sua realidade. ${ }^{48}$

Mais que manifestações populares no sentido tradicional, as "obras da cultura popular" se reportam às atividades realizadas pelos centros de cultura. Da perspectiva da ação política, deriva de imediato à questão dos intelectuais e da organização da cultura. Trata-se, em última instância, de secretar um corpo de intelectuais que possa organizar a cultura popular, mas não a cultura global, visto que aquela é definida em termos restritos, em contraposição à cultura alienada das classes dominantes. Para isso o intelectual deve ser "parte integrante do povo".

Enquanto ideal social, a cultura é ameaçada pela globalização neoliberal porque nela o consumismo, sujeito à exploração capitalista, está submetido a uma cultura oferecida como mercadoria governada pelo lucro, como foi

\footnotetext{
${ }^{48}$ Renato ORTIZ, Cultura Brasileira e Identidade Nacional, p. 72.
} 
analisado no capítulo anterior. Assim, a cultura torna-se um bem de consumo que pode ser comprado, e por essa razão pode adquirir a conotação de não cultura.

O que temos visto é uma cultura consumida através dos veículos de comunicação de massa: televisão, jornais, rádio, cinema, propaganda e o que tem sido oferecido é um "produto" de baixa qualidade porque, para ser consumido pela massa, é preciso ser nivelado por baixo, ou seja, cultura de fácil entendimento, o que é traduzido pelos mais intelectualizados por baixa qualidade.

A cultura como arte no pós-modernismo foi amplamente analisada por Jean Baudrillard. Com sua noção de cultura simulacional, salienta que as mercadorias de consumo no capitalismo desenvolveram a capacidade de incorporar associações imagéticas e simbólicas transformando-se em mercadorias-signos. Para o autor a cultura é apresentada em meio aos demais objetos de consumo, como acessório de luxo, transformada em substância lúdica. Afinal é possível oferecer, no mesmo grande e irresistível espaço, lanche, vestido, curso de idiomas, tratamento estético, disco, flores, cinema e livros, enfim, um pouco de tudo. Para especificarmos ainda mais, no mesmo espaço - uma banca de jornal, por exemplo - é possível encontrar jornal, revista em quadrinhos, publicação sobre sexo, livro de bolso, dicionário, revista de variedades, livro de arte e livro de idéias. O autor atribui o termo culturalizar substituindo o prostituir (a cultura) nesse afã de consumo.

Baudrillard acentua também a importância do consumo na comunicação de massa, observando que ela não nos fornece a realidade, sentimo-nos vivenciar situações às quais não estivemos presentes. 0 jornalismo, em especial o telejornalismo, através da espetacularização, nos permite vivenciar o fato sem o risco de estar em cena. De novo, o simulacro nos leva aos signos do real, parecendo-nos estar vivendo o real - a presença imaginária. É ao que o autor se refere quando fala do cinema-verdade, da reportagem direta, o flash, a foto de choque e o 
testemunho-documento, entre outros, na busca pelo "coração do acontecimento".

Baudrillard detecta uma mudança qualitativa na intensificação desse processo que conduz à perda da noção de realidade concreta, à medida que a cultura consumista - televisionada, repleta de imagens e signos produz uma sucessão infinita de simulações que neutralizam umas às outras. Trata-se de um movimento em direção às formas culturais figuradas que enfatizam a ausência de mediações e a intensidade das sensações auditivas e visuais, proporcionando prazeres caóticos e dispersos para sujeitos descentrados. ${ }^{49}$

Já para M. Featherstone ${ }^{50}$, a cidade pós-moderna está mais consciente de sua própria dimensão imagética e cultural: ela é um centro de consumo cultural, tanto quanto de consumo geral que não pode ser desvinculado dos signos e imaginários culturais. Dá exemplos da arquitetura e da decoração, a mistura de estilos e simulação lúdica de mercadorias, na qual a cultura popular contemporânea (moda, música, televisão, vídeos, bebidas, danças) está dominada pelo mundo do "faz-de-conta" da publicidade. Roupas, corpos e caras transformam-se em citações do lado imaginário da vida: a moda, o cinema, a publicidade e a sugestibilidade infinita contemporâneos.

Entre os estudiosos latino-americanos, Néstor García Canclini contribui significativamente para o estudo da cultura e da sociedade, pois seus estudos enfocam uma substituição da teoria da dominação pela teoria da hegemonia. Para ele "a cultura é o conjunto de processos onde se elabora a significação das estruturas sociais, onde se as reproduz e transforma mediante operações simbólicas". 51

Para García Canclini, entre os anos 70 e 80, analisar a cultura correspondia a descrever as estratégias de dominação. Não tinha um objetivo científico, mas tratava de desvelar as astúcias do poder, a manipulação das

\footnotetext{
49 Jean BAUDRILLARD, Simulacros e Simulação, p. 104.

${ }^{50}$ Mike FEATHERSTORNE, Cultura de Consumo e Pós-Modernismo, p. 140-141.

${ }^{51}$ Néstor GARCÍA CANCLINI y Rafael RONCAGLIOLI, Cultura Transnacional y Culturas Populares, p. 29.
} 
consciências - essa era a única razão pela qual as massas não tinham energia revolucionária. A teoria sociológica, principalmente a que tratava da comunicação, examinou os processos culturais a partir do modelo construído pela teoria da dependência. A mídia - rádio, TV e publicidade estavam confinadas à teoria da dependência e contribuíam para superestimar o papel da política dominadora sobre a consciência popular. Considerava:

1- "o poder era onipresente, a estratégia dos dominadores sobre os dominados;

2- os consumidores passivos e incapazes de distinguir o valor de uso, valor de troca e o valor simbólico;

3- não se reconhecia nenhuma autonomia às culturas populares;

4- a relação entre consumidores, objeto e espaço social, foi concebida como simples lugar pretexto para que o capital realizasse seu lucro e sua manipulação;

5- sob a influência de Gramsci se prestou mais atenção à capacidade de réplica das classes subalternas".

$\mathrm{Na}$ década de 90, o avanço dos movimentos políticos alternativos fomentou uma visão oposta às das décadas de 70 e 80 , quando se pensou a cultura subalterna e a hegemônica numa relação de oposição. Com a idéia de que a cultura hegemônica pressupõe dominação e a cultura subalterna resistência, as pesquisas se detinham em averiguar como uma e outra cultura desempenhavam os seus papéis.

Para sair desse impasse, García Canclini sugeriu uma outra teoria, ou outros recursos metodológicos. As derrotas de movimentos revolucionários, a crise de paradigmas políticos liberais e populistas, 0 interesse científico e político pelo consumo e a organização popular estão nas bases de uma nova maneira de analisar o que se chama de oposiçãol dominação.

Para o autor, o campo da cultura e da comunicação não pode ser visto meramente com um espaço de exercício unilateral, total e sem espaço de reelaboração. Desta forma, o exercício da hegemonia, no conceito de Gramsci, comporta não só a dominação, mas um consenso criado, um pacto, onde determinadas demandas expressas pelas classes subalternas são reelaboradas pelos setores hegemônicos. 
Desta mudança no objeto o autor aponta três conseqüências metodológicas:

1- "analisar os agentes sociais. Não se pode acreditar que os aparatos ideológicos funcionam para manipular as consciências e empurrar o consumismo. $E$ também pensar que as organizações populares representam invariavelmente os interesses das classes populares."

Não existem setores ou aparatos que se dediquem o tempo todo à dominação e nem outros tão conscientizados que viveriam somente para resistir. Há de se pensar as relações sociais como uma luta entre poderes diversos (econômicos, políticos, religiosos, sexuais) que não são de domínio exclusivo de uma classe ou instituição.

2- “A hegemonia não atua de forma impositiva nem unidirecional. As classes hegemônicas, quando querem ser eficazes, não podem limitar-se à imposição. As ações hegemônicas são eficazes pelo que nelas existe de serviço às classes populares. As classes populares prestam 0 seu consenso, concedendo legitimidade à hegemonia."

Ao tratar de hegemonia e não de dominação, o vínculo entre as classes se apóia no contrato, numa aliança entre os subalternos e os hegemônicos - prestação recíproca. Combina-se a demanda expressa pelos subalternos com os interesses da produção dos dominantes.

3- "Os bens e as mensagens hegemônicas interagem com códigos perceptivos e hábitos cotidianos das classes populares." 52

As produções hegemônicas condicionam as opções dos setores subalternos, e estes combinam e selecionam os materiais recebidos construindo um outro sistema que não são um eco automático da oferta hegemônica. O caráter transnacional do sistema se afirma através da reorganização eletrônica das informações e da comunicação.

Para García Canclini, é inegável que a América Latina viveu um período de modernização e expansão econômica e cultural. Teve uma fase de desenvolvimento sustentado e diversificado, um crescimento

\footnotetext{
${ }^{52}$ Néstor GARCÍA CANCLINI y Rafael RONCAGLIOLI, Cultura Transnacional y Culturas Populares, p.3237 .
} 
industrial do mercado interno e que essa concepção desenvolvimentista possibilitou um crescimento, superando o perfil agro-exportador dos seus países. Se por cultura entende-se "o conjunto de processos material-simbólicos através dos quais se compreende, reproduz e transforma a estrutura social", a reorganização conservadora da cultura pode dar-se com a reconstrução do consenso ideológico necessária para o estabelecimento de uma nova hegemonia.

O que deveria ser investigado para conhecer as relações entre cultura transnacional e culturas populares é de que modo as mudanças político-econômicas se combinam com as reformulações das políticas culturais para promover uma nova cultura, um novo sentido da vida social. Para García Canclini, as culturas populares existem porque a reprodução desigual da sociedade gera:

a) "uma apropriação desigual dos bens econômicos e culturais nas diferentes classes na produção e no consumo.

b) uma elaboração própria de suas condições de vida e uma satisfação específica de suas necessidades nos setores excluídos da participação plena no produto social.

c) uma interação conflitiva entre as classes populares com as hegemônicas pela apropriação dos bens sociais."

Desta forma, a cultura relaciona-se com o consumo, e este, por sua vez influencia a formação das identidades de classes. Para tanto, o autor define o consumo da seguinte forma:

a) "o consumo é o lugar de reprodução da força do trabalho e de expansão do capital. As necessidades estão organizadas de acordo com os interesses das classes hegemônicas;

b) o consumo é o lugar onde as classes lutam pela apropriação do produto social, um lugar onde os conflitos emergem originados pelas desigualdades;

c) o consumo é o lugar de diferenciação social e distinção simbólica entre as classes, uma área fundamental para construir e comunicar as diferenças entre os grupos. A diferença se produz não só pelos objetos que possuem, mas também pela forma de usá-los: a escola dos filhos, os rituais de alimentação, 


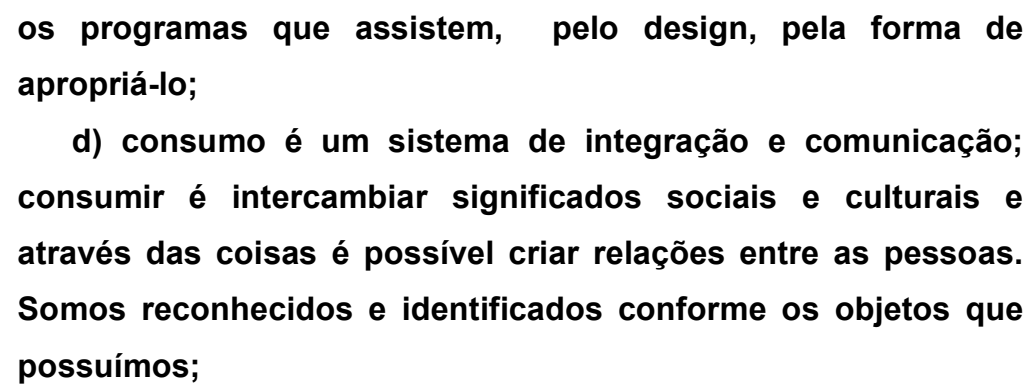

e) o consumo é o lugar de objetivação do desejo. Além das necessidades culturalmente elaboradas, atuamos perseguindo os desejos sem objetos, impulsos que não levam à posse de coisas precisas ou em relação às pessoas físicas." 53

Assim, Garcia Canclini redefine o conceito de consumo, por meio do qual referenciam-se as interações sociais. É na vida cotidiana, antes vista como espaço de reprodução da força de trabalho, que se produz ativamente a sociedade, pela e para a maioria das pessoas, construindo sentidos e cultura. A comunicação se efetiva nos modos de interação, não só com as mensagens, mas com a sociedade, com outros atores sociais, de sujeito para sujeito.

Portanto, o consumo como conjunto de processos sócio-culturais e a vida cotidiana são elementos formadores de um espaço onde o sujeito toma o sentido do pertencimento; este é o novo "espaço público". Sem o sentido do pertencimento, não se pode considerar o sujeito como propulsor ativo da sociedade.

Para Mauro Wilton de Sousa, o pertencimento:

..."parte da esfera subjetiva para se realizar na dimensão de algo que ora é chamado de comum, ora de público, mas de alguma forma traduz a desocultação e sintonia das práticas vividas no cotidiano e sua realização no social e cultural mais amplo, sua realização na

\footnotetext{
${ }^{53}$ Néstor GARCÍA CANCLINI y Rafael RONCAGLIOLI, Cultura Transnacional y Culturas Populares, p. 49.
} 
busca do estar junto coletivo. É essa dimensão de comum que também os diferencia". ${ }^{54}$

Pode-se inferir que uma rádio comunitária é o novo espaço público, pois pode estar legitimando-se como um ator social, em comunhão com uma comunidade, na busca de seus valores e na ressignificação de sua cultura.

$\mathrm{Na}$ base dos estudos culturais britânicos, destaca-se Stuart Hall, que enfoca a questão identitária e a sua relação com as manifestações culturais, sob o alcance político-cultural da globalização. Para o autor ${ }^{55}$, o fenômeno da globalização interfere diretamente na conceitualização de identidade cultural, e suas conseqüências enquanto "pluralização" de identidades, coloca-se diante do jogo de identidades.

Este "jogo" se dá porque muitas vezes as identidades são contraditórias ou se cruzam mutuamente, pois nenhuma identidade singular pode alinhar todas as identidades de forma única, abrangente, conciliando e representando as variadas identidades de uma pessoa. Considera-se ainda que a identificação de um sujeito não se dá de forma automática, ela pode ser ganha ou perdida, dependendo muitas vezes da forma como o sujeito é interpelado ou representado.

Com o processo de globalização e o deslocamento das identidades culturais nacionais, Hall entende três possíveis conseqüências sobre as identidades culturais: a) as identidades nacionais se desintegrarão como resultado do crescimento da homogeneização cultural e do "pós-moderno global"; b) as identidades nacionais, "locais" e "particulares" serão reforçadas pela resistência à globalização; c) as identidades nacionais entrarão em declínio, e novas identidades (híbridas) tomarão o seu lugar. ${ }^{56}$

\footnotetext{
54 Práticas de Recepção Mediática como Práticas de Pertencimento, p.24.

${ }^{55}$ Stuart HALL, A Identidade Cultural na Pós-modernidade, p. 70.

56 Ibid., p.8.
} 
Para o autor, na defesa da identidade das várias culturas no mundo, busca-se defender tradições, pois é através de heranças culturais que o homem cria e recria seu mundo, seu modo de vida, sua própria cultura. A valorização das raízes, das etnias e raças, das religiões, da história partilhada, das manifestações culturais, das expressões artísticas, deve ser a base onde se estruturam os processos de identidade. Nesse aspecto, pode-se dizer que "identidade" configura-se como fonte de experiência de um povo.

A globalização predomina também na identidade particular do homem contemporâneo, pois ele é capaz de modificar toda a estrutura social tanto do seu espaço local quanto do global. Ao ser aculturado, o homem contemporâneo, principalmente o das classes sociais menos favorecidas, muitas vezes, não reconhece mais a própria identidade, obscurecida pela sociedade contemporânea, conflituosa, fragmentada e em constante transformação e adaptação, pois se vive num turbilhão de sentidos onde vige uma multiplicidade infinita de códigos.

Mas, para o autor, o processo de globalização não pode significar plenamente uma hegemonização cultural, apontando três contra-tendências que podem amenizar tal temor. A primeira refere-se ao fato de que, simultaneamente ao poder da globalização neoliberal, verifica-se o encantamento pela diferença. Junto com o impacto global, surge um novo interesse pela diferenciação local. Desta forma, ao invés de pensar-se o global substituindo o local, é necessário pensar numa nova articulação entre o global e o local. ${ }^{57}$

A segunda tendência apontada pelo autor remete a maneira pela qual os indivíduos são tocados pela globalização, porque esta não é distribuída da mesma forma em todas as regiões do mundo. Sua terceira crítica advém do fato de que a globalização atinge essencialmente o mundo ocidental. ${ }^{58}$

\footnotetext{
${ }^{57}$ Stuart HALL, A Identidade Cultural na Pós-modernidade, p. 77.

58 Ibid., p.78.
} 
Em sua obra Da Diáspora - identidades e mediações culturais ${ }^{59}$, Hall entende que a identidade cultural remodela os sentidos e os significados, além de ajustar as definições das pessoas ao modelo cultural predominante, reafirmando, desta maneira, o poder da concentração cultural nas mãos de uma minoria.

Mesmo reconhecendo que tal estrutura não tem o poder de encampar as mentes, ele aponta a condição destas em retrabalhar as contradições internas dos sentimentos e percepções das classes dominadas, enfatizando os efeitos da dominação cultural sobre o comportamento das pessoas. A dominação cultural tem efeitos concretos, mesmo que não sejam todo-poderosos e totalmente abrangentes. Mas, adverte o autor, que:

\footnotetext{
"Afirmar que essas formas impostas não nos influenciam equivale a dizer que a cultura do povo pode existir como um enclave isolado, fora do circuito de distribuição do poder cultural e das relações de força cultural. Não acredito nisso. Creio que há uma luta contínua e necessariamente irregular $\mathrm{e}$ desigual, por parte da cultura dominante, no sentido de desorganizar e reorganizar constantemente a cultura popular; para cercá-la e confinar suas definições e formas dentro de uma gama mais abrangente de formas dominantes. Há pontos de resistência e também de superação. Esta é a dialética da luta cultural." ${ }^{60}$
}

Para Hall, tendemos a pensar as formas culturais como algo inteiro e coerente: ou inteiramente corrompidas ou inteiramente autênticas, enquanto que elas são profundamente contraditórias, especialmente quando funcionam no domínio do popular, combinando e remodelando a linguagem das classes dominantes com os elementos populares. O princípio estruturador do popular são as tensões e oposições entre aquilo que pertence ao domínio central da elite ou da cultura dominante, e a "cultura da periferia". ${ }^{61}$

Defende ainda Hall que o essencial em uma definição de cultura popular são as relações que a colocam em uma tensão contínua - de relacionamento, de influência e antagonismos - com a cultura dominante, considerando os domínios das formas e das atividades culturais como um campo sempre variável. O que importa não são os objetos culturais historicamente

\footnotetext{
${ }^{59}$ Stuart HALL, Da diáspora - identidades e mediações culturais, p. 254.

${ }^{60}$ Stuart HALL, Da diáspora - identidades e mediações culturais, p. 255.

61 Ibid, p. 256.
} 
determinados, mas o estado do jogo das relações culturais, isto é o que conta, é a luta de classes na cultura ou em torno dela e essa luta assume diversas formas, tais como a incorporação, distorção, resistência, negociação e recuperação.

Para o autor, a cultura popular "é um dos locais onde a luta a favor ou contra a cultura dos poderosos é engajada; é também o prêmio a ser conquistado ou perdido nessa luta. É a arena do consentimento e da resistência". ${ }^{62}$

2.2. Identidade cultural, identidade nacional e formação do imaginário

Entre os pesquisadores da cultura existe uma discussão clássica sobre o popular e o nacional popular. Para Renato Ortiz, o popular significa tradicional e se identifica com as manifestações culturais das classes populares, que em princípio preservariam uma cultura "milenar", romanticamente idealizada pelos folcloristas. Dentro dessa perspectiva, o popular é visto como objeto que deve ser conservado em museus, livros e casas de cultura, alimentando o saber nostálgico dos intelectuais tradicionais. Mas a emergência do pensamento folclórico no Brasil está, como na Europa, também associada à questão nacional, uma vez que as tradições populares encarnam uma determinada visão do que seria o espírito de um povo.

Para Ortiz, o estudo da cultura popular é uma forma de manifestação da consciência regional quando ela se opõe ao Estado centralizador. A perspectiva folclorista sobrevive, sobretudo, nas regiões periféricas do país, onde ocorre uma simbiose entre o popular tradicional e as políticas de cultura realizadas pelas secretarias e conselhos municipais e estaduais. Essa simbiose encontra-se associada a uma ideologia das agências governamentais, para as quais 0 argumento da tradição é fundamental na orientação de atividades culturais. Por isso o

${ }^{62}$ Stuart HALL, Da diáspora - identidades e mediações culturais, p. 263. 
teor dessas atividades, que se voltam para a preservação da "memória", dos museus, das festas populares e do artesanato folclórico. “Esse tipo de argumentação legitima ação do Estado nessas áreas, desenvolvendo uma proposta que em princípio recuperaria a memória e a identidade nacional cristalizada no tempo". 63

Porém, afirma o autor que o nacional se define como a conservação "daquilo que é nosso". Assim, a memória nacional seria o prolongamento da memória coletiva popular. A cultura popular se manifesta de forma heterogênea, e não partilham um mesmo traço em comum e nem se inserem num sistema único, é plural, sendo mais adequado falar em culturas populares. ${ }^{64}$

A memória popular, para Ortiz, deve se transformar em vivências, realizadas no cotidiano, e somente assim poderá assegurar sua perenidade, enquanto que a memória nacional se refere a uma história que transcende os sujeitos e não se concretiza imediatamente no cotidiano, situando-se em outro nível, vinculando-se à história. Permanece no domínio da ideologia, configurando-se como um produto da história social e não da ritualização da tradição, que é própria da memória coletiva popular, próxima do mito e que se manifesta ritualmente, encarnado pelo grupo restrito; a ideologia se estende à sociedade como um todo e não é propriedade de nenhum grupo social e se define como universal impondo-se a todos os grupos. ${ }^{65}$

Defende ainda o autor que a memória nacional opera uma transformação simbólica da realidade social, não coincidindo com a memória particular dos grupos populares, assim entendido:

“...O discurso nacional pressupõe necessariamente valores populares e nacionais concretos, mas para integrá-los em uma totalidade mais ampla.

O Estado é esta totalidade que transcende e integra os elementos concretos da realidade social, ele delimita o quadro de construção da identidade nacional. É através de uma política que se constitui assim a identidade; como construção de segunda ordem ela se estrutura no jogo da interação entre

\footnotetext{
${ }^{63}$ Renato ORTIZ, Cultura Brasileira e Identidade Nacional, p. 86.

${ }^{64}$ Renato ORTIZ, Cultura Brasileira e Identidade Nacional, p. 131-134.

65 Ibid., p. 135.
} 
o nacional e o popular, tendo como suporte a sociedade global como um todo. $\mathrm{Na}$ verdade, a invariância da identidade coincide com a universalidade do discurso nacional". ${ }^{66}$

Maria Nazareth Ferreira aborda a questão sobre as assimetrias entre identidade cultural e a identidade nacional, considerando que o homem, desde a sua presença no Universo, vem procurando respostas às questões sobre sua origem e sobre o sentido da vida. A identidade é um pressuposto, imperativo e essencial, para o homem situar-se no tempo, no espaço e no movimento do Universo. Estes três componentes, articulados, estão subjacentes na construção da identidade. ${ }^{67}$

O homem deve conhecer e influenciar o seu espaço, condição fundamental para garantir a sua sobrevivência. Situando-se num determinado espaço, ele inicia a construção de seu espaço individual, que se alarga em espaço nacional. A consciência do tempo, ligada à idéia de movimento, determina a noção de tempo histórico, no qual o homem construiu, por meio da ação, a sua história e a sua memória, depositária de conhecimentos que, em grupo, os homens acumulam, recolhendo-os da vida cotidiana, responsável pela organização de seu presente, do seu passado e do seu futuro, o seu porvir.

Entende a autora que a idéia de movimento implica uma construção mais complexa, ritmo de desenvolvimento e outras facetas bem definidas, diferentemente do nascimento, desenvolvimento e morte inerentes ao ciclo de vida das pessoas. 0 movimento das sociedades ou dos povos não tem morte biológica, resultando daí a "necessidade vital da memória, da história passada, dessa acumulação de experiências a que se dá o nome de cultura". Mas lembra que antes de se discutir a identidade de um povo, de uma cultura, é necessário conhecer a construção da identidade nacional.

\footnotetext{
${ }_{67}^{66}$ Ibid., p. 139.

${ }^{67}$ Maria Nazareth FERREIRA, Identidade Cultural: Resistência ou Dependência (notas acerca da construção da identidade cultural), p. 41.
} 
O Estado, a sociedade política como um conjunto de mecanismos através do qual a classe dominante detém o monopólio legal da repressão e da violência (forças armadas, policiais, aplicação de leis) constrói a idéia de identidade nacional, representada pelo patrimônio cultural, registros dos monumentos da arquitetura, da arte erudita e dos heróis oficiais, ícones selecionados segundo a ótica da elite ou dos elitistas da cultura. Trata-se de um patrimônio que não representa toda a sociedade, mas que dá contornos somente às manifestações culturais das classes dominantes. As diversidades culturais permanecem de fora da representação da identidade nacional, podendo-se concluir que a noção de patrimônio cultural constitui-se numa deformidade do real, porque não representa as demais expressões culturais dos diversos segmentos da sociedade, do povo nação. ${ }^{68}$

É importante lembrar que a identidade nacional não pode ser construída apenas por meio das manifestações das culturas populares. No entanto, para muitos pesquisadores, existe uma relação entre a cultura popular e a questão nacional. Nela reside a possibilidade de transformação da sociedade, a grande força da sua expressividade.

Para Ferreira, porém, dadas as condições atuais da globalização neoliberal, do poder vertical unificador das mídias, e por ser construída de "cima", pelo Estado autoritário, a identidade cultural (nacional), fraturada e violentada e sem condições próprias para resistir a esta fragmentação, necessita do suporte de uma nova configuração cultural para poder construir-se como expressão da sociedade, nação ou povo que representa. É uma nova configuração de patrimônio cultural, que busca valorizar as memórias coletivas, os modos e as práticas da vida, a sensibilidade, o pensamento, a comunicação, diferente daquela noção de patrimônio cultural, estruturado a partir do Estado e da visão elitista da cultura.

\footnotetext{
${ }^{68}$ Maria Nazareth FERREIRA, Identidade Cultural: Resistência ou Dependência (notas acerca da construção da identidade cultural), p. 13.
} 
As investidas da mídia hegemônica têm provocado a perda do referencial das sociedades e o temor pela ameaça do desaparecimento dos seus símbolos culturais e dos seus traços ainda vivos que comprovam o seu passado.

Para Dênis de Moraes, o imaginário social é composto por um conjunto de relações imagéticas que atuam como memória afetivo-social de uma cultura, uma essência ideológica mantida pela comunidade. É uma produção coletiva e o depositário da memória que a família e os grupos acumulam recolhidos do cotidiano. Nessa instância, são identificadas as diversas percepções dos atores em relação a si mesmos e em relação aos outros, ou seja, como eles se percebem como parte de uma mesma coletividade.

Por meio do imaginário se atinge os desejos, os receios, os medos de um povo, e é nele que as sociedades desenham suas identidades e objetivos, identificam os seus inimigos e organizam o seu passado, presente e futuro, como afirma o autor. ${ }^{69}$

O imaginário é um dos modos pelo qual a sociedade apreende a vida e a elabora, refazendo percurso, numa busca incessante pelas utopias, construindo uma ordem simbólica, incorporando os sinais do que já existe como fator de identidade entre os atores. É o símbolo que permite ao sentido engendrar limites, diferenças, tornando possível a mediação social, consagrando-o como ordem irredutível, e como indica Moraes, tornando o real sobredeterminado pelo imaginário.

Nisto consiste a transcendência das ideologias: elas expressam as relações vividas pelo homem. Para Ferreira, na construção da identidade

\footnotetext{
${ }^{69}$ Dênis de MORAES, Notas sobre o imaginário e hegemonia cultural, site - acesso em 14/07/2006
} 
(nacional) se cristaliza a capacidade de um povo de determinar o seu próprio destino, seu porvir individual, de classe e como nação. ${ }^{70}$

É nesse cenário que as identidades são atingidas pelas mídias. $\mathrm{Na}$ sociedade atual, tempo da indústria da comunicação e do marketing, a afetividade, o desejo, o culto ao corpo, o sexo, tornam-se as grandes chaves para a formação do homem contemporâneo.

Produções de linguagem super elaboradas, narrativas verbais e não-verbais, persuasão como estratégia e sedução, centram forças à procura de um alvo: o ego fragilizado que se acredita fortalecido, e dá ao sujeito a sensação de que ele é integrado e reconhecido socialmente como sujeito de sua existência, de seus desejos e das suas atitudes e jamais refém das estratégias dissimuladas dos administradores do consumo.

Deste jogo decorre o esvaziamento da subjetividade humana e a “sujeição" do indivíduo ao processo de desenvolvimento da sociedade capitalista, industrial e pós-industrial globalizada. Orientada pela lógica capitalista, a sociedade incorpora e submete-se ao fetiche, empreende criações destrutivas, inventa desejos, elabora e tira proveito de novas capacidades, modifica o uso e a representação do tempo e do espaço, alterando os modos de vida.

Em meio à rapidez com que as mudanças se processam, o indivíduo não mais reconhece seu ambiente de individualização, não sabe da sua própria identidade, tornando-se difícil manter o sentido de continuidade histórica, que serve de referência à formação da identidade, diante da fluidez de efemeridades. No momento em que vê ruir as promessas de bem-estar e de progresso, o sujeito tenta se auto-afirmar a partir de criações de particularismos na busca da identidade, e em meio a

\footnotetext{
${ }^{70}$ Maria Nazareth FERREIRA, Culturas da Comunicação, III Simpósio Internacional do CEBELA, p. 44.
} 
esse processo, o homem assume uma atitude cada vez mais defensiva. Os pichadores de muro, de trens, de monumentos, parecem demonstrar uma identidade sufocada pela dissimulação das estratégias do neoliberalismo.

Esse comportamento pode decorrer do esvaziamento do sentido da sua existência, pela manipulação do imaginário. $O$ imaginário de um povo revela-se por meio de seus instrumentos de comunicação que são utilizados para a sua expressão. Os modos de apropriação pela indústria cultural são altamente danosos para as expressões do imaginário popular, à medida que são "espetacularizados" para o consumo das grandes massas, esvaziando o seu caráter mágico, mítico e religioso, roubando das pessoas o seu maior bem: o direito à sua cultura e às suas raízes, que fortalecem o sentido da sua existência.

A necessidade de auto-afirmação, a incansável busca por respostas a si mesmo, permite emergir situações contraditórias. Ao mesmo tempo em que se verifica a desterritorialização, que rompem as fronteiras antes demarcadas pela cultura, pela língua, pelos valores nacionais, constata-se um desabrochar de novas identidades regionais e locais alicerçadas numa revalorização do direito a raízes, percebido pela onda de nascimento de museus, memória, casa de cultura, e outros, correspondendo à necessidade imperativa de resistir à desestruturação cultural, provocada pelas mídias.

A presença da indústria cultural, num primeiro momento, busca homogeneizar e se impor sobre as culturas populares, indiferente às realidades dos lugares e das sociedades. Mas, essa conquista jamais é completa, como afirma Santos, pois encontra a resistência da cultura preexistente, surgindo daí, a possibilidade de uma revanche das culturas populares sobre a cultura das mídias, quando ela se difunde por meio dos instrumentos que na origem são próprios da cultura de massa. Neste caso, "a cultura popular exerce sua qualidade de discurso dos "de baixo", 
pondo em relevo o cotidiano dos pobres, das minorias, dos excluídos, por meio da exaltação da vida de todos os dias. "71

Assim, a cultura dos "de baixo", por ser baseada no território, no trabalho e no cotidiano, e sem possibilidades de dispor dos meios para participar da cultura de massa, ganha força necessária para deformar a cultura de massa, pois, gente junta, cria economia, cultura e política territorializados. $\mathrm{O}$ que aparentemente seria uma fraqueza é na verdade uma força, já que assim se realiza uma integração orgânica com o território e o seu conteúdo humano. ${ }^{72}$

Disto resulta a expressividade de seus símbolos, de sua fala, de suas cores, de seu ritmo, da sua comida, da suas preces e súplicas, todos os seus valores, evoluindo de modo inseparável, assegurando a permanência do movimento e o fortalecimento da identidade, como se pretende analisar nesta pesquisa.

A indústria cultural produz símbolos a serviço do poder ou do mercado. São símbolos fixos e morrem quando são substituídos por outros, também fixos, de interesses do mercado. Os símbolos dos "de baixo", produzidos pela cultura popular, portam a verdade da existência e revelam o próprio movimento da sociedade. Neste processo, a expressividade da identidade cultural e do imaginário tem a força de poder atribuir um novo sentido à existência de cada sujeito, individual ou coletivo, conduzindo à realização de uma vida coletiva solidária.

\subsection{As manifestações culturais populares}

É dever de uma rádio comunitária, como foi visto no capítulo anterior, estar em sintonia com as manifestações culturais, artísticas ou folclóricas e de informar sobre as atividades de lazer de uma comunidade, estando assim, em diálogo com o sentimento popular, expresso nas suas manifestações estéticas.

\footnotetext{
${ }_{71}^{71}$ Milton SANTOS, Por uma outra Globalização: do pensamento único à consciência universal, p. 144.

72 Ibid., p. 146.
} 
Tomando-se a definição de García Canclini, o popular é próprio das classes subalternas e caracteriza-se como espaço onde coexistem concepções do mundo herdadas do passado (tradições) e elementos modernizantes, do mundo em formação, como conseqüência das atuais condições de vida das classes subalternas.

O popular caracteriza-se, ainda, como cenário contraditório no qual coabitam elementos culturais conservadores readaptados e ressignificados nas concepções de mundo das elites dominantes e elementos transformadores, derivados da práxis social das classes populares. Desta forma, o popular é por definição, histórica e essencialmente oposto ao oficial ou, pelo menos, diferente dele. ${ }^{73}$

Como foi visto com García Canclini no item anterior deste capítulo, a reprodução desigual de bens quase sempre gerando uma também desigual apropriação dos bens econômicos e culturais, estabeleceria uma maneira própria, historicamente determinada, de elaborar condições para que a sociedade possa atender suas necessidades materiais e simbólicas de sobrevivência.

Nesta perspectiva, os segmentos populares e excluídos, possibilitaram formas peculiares de participação na produção social de modo a estabelecer uma interação conflitiva entre as classes populares e as hegemônicas na disputa pela apropriação dos bens sociais. Desta maneira, o autor compreende que se busca romper com a concepção unidirecional de poder, resgatando as horizontalidades além das verticalidades das estruturas econômicas, políticas, simbólicas e culturais.

Como diz Milton Santos:

"No lugar - um cotidiano compartido entre as mais diversas pessoas, firmas e instituições - cooperação e conflito

\footnotetext{
${ }^{73}$ Néstor GARCÍA CANCLINI y Rafael RONCAGLIOLI, Cultura Transnacional y Culturas Populares, p. 23.
} 
são a base da vida em comum. Porque cada qual exerce uma ação própria, a vida social se individualiza; e porque a contigüidade é criadora de comunhão, a política se territorializa, com o confronto entre organização e espontaneidade. O lugar é o quadro de uma referência pragmática do mundo, do qual the vêm solicitações e ordens precisas de ações condicionadas, mas é também o teatro insubstituível das paixões humanas, responsáveis, através da ação comunicativa, pelas mais diversas manifestações da espontaneidade e da criatividade ". ${ }^{74}$

No Brasil, povoado de multiplicidade de lugares e de diversidades culturais, as mais variadas manifestações de espontaneidade e de criatividade interagem-se perfazendo o vasto e complexo repertório existente no país, revelando uma mesclagem, absorvendo as vertentes culturais. O país possui uma riquíssima cultura popular, nascida da contribuição de quatro fontes principais: as culturas negra, portuguesa e indígena, e a contribuição posterior do imigrante. Cada região brasileira manteve ou modificou, em graus diferentes, os traços dessa cultura herdada, dentro da tendência universal de aculturação, sempre mais intensa na razão direta do desenvolvimento do meio urbano. Como diz Luis da Câmara Cascudo:

\footnotetext{
“... Antes de o primeiro brasileiro nascer, indígenas, portugueses e escravos africanos dançavam há muitos séculos. Era fórmula de louvar a Deus, agradecer ou suplicar favores, comemorar vitórias na caça ou na guerra.

As danças, inicial e unicamente religiosas, no Brasil acompanhavam as procissões e viviam dentro das igrejas até o século XVIII.

A sociedade dançou muito depois do povo. As festas oficiais começaram com as recepções dos vice-reis no Rio de Janeiro na segunda metade do século XVIII. As festas, antes, eram as da igreja. O povo é que sempre dançou suas danças, como ainda costuma, acima de qualquer figurino momentâneo". ${ }^{75}$
}

A cultura negra teve dois focos principais de gestação: a Bahia e o Rio de Janeiro, embora também presente no restante do Nordeste e em Minas Gerais, sobretudo na música, na dança, na religião popular e na cozinha.

A cultura indígena foi a que deixou traços menos visíveis, devido principalmente ao pouco desenvolvimento que alcançou ao entrar em contato

\footnotetext{
${ }_{74}^{74}$ Milton SANTOS, O lugar e o cotidiano, texto introdutório.

${ }^{75}$ Luis da Câmara CASCUDO, Cultura Popular e Folclore, p.8-10.
} 
com culturas mais fortes. É visível ainda na cozinha, na música e em manifestações isoladas e em extinção, como os caboclinhos do Nordeste.

A cultura portuguesa manteve-se principalmente no sul do país, onde as levas de imigrantes continuaram a suceder-se no século XX. Em muitos estados brasileiros, são comuns as sociedades portuguesas, que correspondem a diversas regiões de Portugal, e que realizam um trabalho concreto de preservação de sua cultura, principalmente canto e dança. A presença da herança portuguesa na cozinha brasileira é definitiva.

As culturas populares guardam as tradições dessas fontes nos sabores da culinária, nas músicas, nas danças, nas devoções, na manufatura de artefatos, no cordel, nos repentistas, nas festas e seus trajes de celebração, no teatro de rua, nos brincantes, nas advinhas, nos campinhos de futebol e tantas outras formas de representações coletivas. Essas manifestações engendram valores estéticos e simbólicos onde se pode vislumbrar a origem trans-regional e pluricultural que marcam as diversidades das manifestações culturais do país. Nessas manifestações são elaborados os processos de transmissão e recepção dos valores já existentes com a cultura globalizada, valores esses que caracterizam a dualidade cultural, mas que têm grande força na realização, no momento privilegiado de sua celebração coletiva.

O imaginário brasileiro vai modificando-se em suas formas e conteúdo, mesclando o que recebeu do imaginário universal - da cultura moura, das múltiplas culturas africanas, das culturas aborígenes que estão caldeadas na sua formação. ${ }^{76}$

Entre as manifestações populares, as festas destacam-se no gosto do povo brasileiro, atraindo a participação de comunidades das mais diversas localidades, do norte ao sul do país, desde o interior até as regiões litorâneas, que permitem avaliar como o passado e o presente se articulam no interior destas culturas e as várias formas de identidades que são ao mesmo tempo ressignificadas, assumindo novos aspectos.

${ }^{76}$ Roberto BENJAMIN, O imaginário popular como fator de desenvolvimento da arte, p. 26. 
São festas de cunho sagrado e profano que se multiplicam nos milhares de municípios, portando as suas diferenças e suas singularidades interpretativas: festas do Divino, festas de São Benedito e de Nossa Senhora do Rosário, em que devotos cumprem promessas feitas, Jongos, Congadas, do saci pererê, festa de Santa Cecília (a padroeira dos músicos), festas juninas, reisados, moçambiques, festas de padroeiros das cidades, folguedos natalinos, como a lapinha, o pastoril e a barca; carnaval, com manifestações próprias no Rio (escolas de samba e bandas), e tantas outras manifestações festeiras.

Para Alceu Maynard Araújo, o aparecimento da festa data das mais remotas eras, quando o homo faber deixa de ser mero coletor de alimentos, praticante da técnica de subsistência da catança, e passa a cultivá-los, plantando-os. Para o autor:

“... Há na aurora das festas aquela preocupação mágica de agradecer a natureza ou suplicar para que ela, entidades supraterrenas ou divindades, não permitam as pragas, danos ou malefícios nas plantações, praticando, portanto ritos protetivos e produtivos.

A festa interrelaciona-se não só com a produção, mas também com os meios de trabalho, exploração e distribuição, ela é, portanto conseqüência das próprias forças produtivas da sociedade, por outro lado, é uma poderosa força de coesão grupal, reforçadora da solidariedade vicinal cujas raízes estão no instinto biológico da ajuda, nos grupos familiares.

O grupo social repetindo em consonância com essa periodicidade nos ciclos agrícolas, as reuniões, acabou dando à festa uma função comemorativa.

À festa, com o correr do tempo, foram se associando outros elementos tais como padroeiros, entidades sobrenaturais, mais tarde substituídas pelos santos do hagiológio católico romano". ${ }^{77}$

As festas são tão significativas para o homem, como ser comunicativo e social, que se pode afirmar que não existe sociedade humana sem festas. Fazer festa significa colocar-se diante do espelho, procurando a si mesmo e à sua identidade; é buscar reencontrar as garantias histórico-culturais, reconfirmando-as na força da representação, no ato comunicativo e comunitário. Esta ação de resgatar a própria identidade é fundamental para encontrar-se a si mesmo e recuperar um equilíbrio que pode estar ameaçado, como analisa Maria Nazareth Ferreira. ${ }^{78}$

\footnotetext{
${ }^{77}$ Alceu Maynard ARAÚJO, Cultura Popular Brasileira, p.25.

${ }^{78}$ Maria Nazareth FERREIRA, As Festas Populares na expansão do turismo: a experiência italiana, p.13-15.
} 
Para a autora, as festas possibilitam uma construção sólida da identidade cultural, dotando a comunidade envolvida de conscientização e de pertencimento a ponto de se manter íntegra em seus fundamentos originais, conservando raízes, tradições e valores, mantendo-se firme, inclusive moralmente e senhora de seu destino.

As festas populares têm, ainda, a capacidade de gerar renda em pequenas localidades distantes dos intensos fluxos financeiros da economia globalizada. "Gente junta cria festa e festa gera economia", disse Milton Santos.

A festa deve ser vista como um conjunto de atos cerimoniais de caráter coletivo pela sua colocação dentro de tempo delimitado, e "diverso" da cotidianidade. Em qualquer tipo de festa, o grupo ou a comunidade interrompe o tempo carregado de implicação cultural, diferente daquele tempo ordinário ou cotidiano, vivenciando uma experiência cultural de outra ordem. O tempo festivo possui uma dupla e contraditória relação entre conservação e criatividade cultural. Ferreira observa que a festa empurra o indivíduo à fuga, à evasão da realidade banal, do cotidiano, para mergulhar no momento mágico da festa, por meio do riso, do jogo, da dança, da música, da alegria, do descontrole orgiástico, do dramático, etc. ${ }^{79}$

Para Anibal Quijano, é o momento de sua "gran fiesta del origen", momento da celebração coletiva, que na América Latina tem o seu lugar privilegiado, e em que a estética e a utopia são evocadas e requeridas como forma de libertação dos dominadores, que desonram o legado cultural das suas populações.

Para ele, a estética e a utopia são feitas da mesma matéria, pois ambas são engendradas pela busca da libertação, tanto na sua materialidade, quanto na sua subjetividade. ${ }^{80}$ É mundo complexo, revelador e redentor da sociedade que o produz. Além das implicações econômicas que possam traduzir, o seu

\footnotetext{
${ }^{79}$ Maria Nazareth FERREIRA, As Festas Populares na expansão do turismo: a experiência italiana, p.17.

${ }^{80}$ Anibal QUIJANO, Estética de la Utopia, p. 193.
} 
caráter de produção cultural deve ser avaliado enquanto expressão dos valores originais e originários de um povo.

E nisto reside a capacidade redentora da rádio comunitária: promover o pluralismo dos modos de produção simbólica, voltados para a produção do comum, que emerge da diferença frente ao oficial.

Neste contexto, a alegria é o grande diferencial dessas expressões constituintes de um comum. Como apresenta Muniz Sodré ${ }^{81}$, na comunicação alternativa, pode se autopotenciar a alegria, grande vetor de singularização. $\mathrm{Na}$ cultura midiática, tecnologicamente produzida, dependente de causas e finalidades comandadas pelo mercado, há sensação, emoção, vertigem e promessas de felicidade - jamais alegria.

A alegria prioriza afetivamente o real humano em seus aspectos familiares e também o imaginário direta ou indiretamente articulado ao sagrado. A alegria acontece onde a vida possa afinar-se ludicamente com o mundo em suas manifestações espontâneas, emergindo como a ponta extrema dessa celebração coletiva.

“A alegria é sem pecado, sem perdão e sem submissão”, exalta Sodré.

\footnotetext{
${ }^{81}$ Muniz SODRÉ, As Estratégias Sensíveis - afeto, mídia e política, p. 222.
} 


\section{CAPÍTULO 3}




\section{São Luis do Paraitinga e}

\section{a tradição festeira do Vale do Paraíba}

\section{São Luis do Paraitinga e a tradição festeira do Vale do Paraíba}

\section{"Aqui, quando acaba uma festa, começa} uma outra."

Morador de São Luis do Paraitinga

\subsection{O Vale do Paraíba histórico e cultural ${ }^{82}$}

O Vale do Paraíba é uma região de passagem e ligação, desde os tempos coloniais, constituindo-se em caminhos para as Minas Gerais, para os portos do litoral, para o planalto de São Paulo, e para a cidade do Rio de Janeiro. Por estes caminhos foram desbravados sertões, povoadas muitas capitanias distantes e fundadas vilas e cidades. O Vale do Paraíba, desta forma, tem uma importante participação no movimento da Independência, na sustentação econômica do Império Brasileiro, contribuindo ativamente na vida política e social do Brasil e, hoje, se apresenta como a região mais importante

\footnotetext{
${ }^{82}$ Site www.estudosvaleparaibanos.com.br , acesso em 13/07/2006.
} 
no processo de industrialização e urbanização do Brasil e da América do Sul, como explica José Luiz Pazin.

Para o autor, a economia valeparaibana sempre esteve baseada na agricultura e nas atividades ligadas a terra: açúcar, café, algodão, fumo, milho, feijão e outros produtos secundários. No início do seu povoamento, a economia que era de subsistência, deu lugar à monocultura açucareira e, posteriormente, ao grande ciclo produtor de café.

O Vale do Paraíba tornou-se uma região agrícola das mais importantes de São Paulo e suas terras ainda hoje constituem um desafio para o aumento de uma produção racional de cereais, capaz de garantir o seu abastecimento. Afirma Pazin que a ocupação e a utilização das várzeas do Rio Paraíba teve início na segunda metade do séculoXIX, com a implantação de colônias agrícolas pelo governo provincial, a partir de 1850, nos municípios de Lorena e de Pindamonhanga.

No final do Império foram criadas mais cinco colônias agrícolas no Vale do Paraíba: Canas, em Lorena (1885); Boa Vista, em Jacareí (1888); Quiririm, em Taubaté (1890); Piagui, em Guaratinguetá (1892); e a de São José do Barreiro. A implantação destas colônias agrícolas resultava da necessidade de se ocupar as várzeas do Paraíba e as áreas livres dos municípios, tendo em vista o domínio absoluto do café e as crises periódicas de abastecimento de cereais e de legumes na região. Lembra o autor que estas colônias eram integradas predominantemente por famílias de origem italiana, como também por alemães, portugueses, espanhóis, suíços, austríacos e outras nacionalidades.

A introdução e o cultivo racional do arroz, como atividade agrícola básica da região, foi iniciada pelos monges trapistas, em terras localizadas no município de Tremembé. O arroz é o principal produto agrícola cultivado no Vale do Paraíba, destacando-se as áreas de São José dos Campos, 
Caçapava, Pindamonhangaba, Roseira, Guaratinguetá e Lorena. Além do arroz, a produção agrária da região se caracteriza pelo cultivo do milho, tomate, batata e feijão. Sendo uma região de clima temperado e de terras férteis, o Vale se caracteriza pelo cultivo de todos os cereais, frutas e leguminosas, tais como: trigo, aveia, sorgo, centeio, cevada, tâmara, uva, oliva, coco, maçã, pêra, abacaxi e todas as frutas de clima quente ou tropical.

Nos municípios localizados nos arredores da Serra do Quebra Cangalha (Cunha, Lagoinha, São Luís do Paraitinga) a população vive basicamente das suas roças de milho e feijão, e da criação de porcos e galinhas. A utilização racional das várzeas, a mecanização das propriedades, a construção e melhoria das estradas rurais, as obras de contenção das enchentes do Rio Paraíba, a assistência efetiva dos vários órgãos oficiais, asseguram a propriedade agrícola na região valeparaibana, pólo gerador de empregos e divisas para os municípios.

Com a decadência do café, o Vale do Paraíba buscou novas atividades econômicas. Nas áreas rurais deu-se a substituição dos cafezais pelas pastagens e, nas cidades, o início de um lento processo de industrialização.

As primeiras indústrias surgiram na região nas últimas décadas do século XIX, quando se colocava o desafio de buscar novas opções, refletindo a realidade sócio-econômica da época: abolição da escravatura, disponibilidade de capital, melhoria do nível de consumo da população.

A situação geográfica da região, localizada entre os dois maiores centros produtores e consumidores do país - São Paulo e Rio de Janeiro - e as facilidades de comunicação, ampliadas com a construção da Estrada de Ferro Central do Brasil (antiga Dom Pedro II), foram fatores decisivos para o início da industrialização do Vale do Paraíba, que se fez em proporção crescente. Um mapa da região, o Anexo I, mostra toda a região do Vale do Paraíba.

O autor, baseando-se na data de fundação das principais indústrias hoje existentes, conclui que o processo de industrialização da região valeparaibana desenvolveu-se em três fases distintas: a primeira iniciada nas duas últimas 
décadas do século XIX; a segunda, abrangendo o período compreendido entre as duas grandes guerras, tendo como pólos principais: Jacareí, São José dos Campos, Taubaté e Guaratinguetá; e a fase atual - que teve início nos anos 1930, a mais dinâmica, iniciada com a construção da Usina Siderúrgica de Volta Redonda e com a inauguração da Rodovia Presidente Dutra, esta em maio de 1928, criando novos centros de desenvolvimento e tecnologia: São José dos Campos, Jacareí, Caçapava, Cruzeiro, Lorena e Pindamonhangaba.

Nesta última fase instalam-se as indústrias de grande porte, mecânicas, modernas: Johnson, Ford, General Motors, Volkswagen, Nestlé, Ericsson, Kodak, Villares, Fuji, Basf, Avibrás, Mafersa, Liebherr, Monsanto, destacandose ainda as indústrias químicas, metalúrgicas, de papel e celulose, têxteis e alimentícias. São José dos Campos constitui hoje o maior centro de tecnologia avançada na América do Sul (EMBRAER, INPE, CTA).

Nos seus aspectos ambientais, o autor considera que o Vale está localizado entre a Serra da Mantiqueira e os contrafortes da Serra do Mar, possuindo uma paisagem botânica e animal das mais exuberantes na fauna e na flora do Brasil.

O Rio Paraíba do Sul, formado pela junção dos rios Paraitinga e Paraibuna, com sua rica rede de afluentes, que alcançam os Estados do Rio de Janeiro e Minas Gerais, possui uma das grandes bacias hidrográficas da América do Sul, com uma variedade de peixes e abundância de águas, responsável pelo abastecimento de numerosas cidades por ele banhadas.

O crescimento acelerado e desordenado das cidades registrado nos últimos anos, a multiplicidade de atividades industriais, a excessiva valorização das terras, vêm produzindo efeitos negativos sobre o espaço ambiental na região valeparaibana. Muitas organizações, como associações civis, movimentos ecológicos e iniciativas governamentais procuram preservar o que restou da cobertura vegetal original nas serras que margeiam o Vale. $O$ Governo Federal criou, em 1937, o Parque Nacional de Itatiaia, o mais antigo do Brasil, e o Parque Nacional da Serra, abrangendo a região de Bananal e de São Luís do Paraitinga. O Governo de São Paulo mantém os parques 
estaduais de Cunha, São Luís do Paraitinga, Campos do Jordão e Caraguatatuba-Ubatuba. Também foram criadas Áreas de Proteção Ambiental nos municípios de Silveiras, Campos do Jordão, Jambeiro e Roseira.

Quanto aos seus aspectos culturais, Pazin considera que por estar localizado entre os dois maiores centros culturais do país, o Vale do Paraíba tem condições para desenvolver um programa de integração cultural voltado para a realidade social da região, absorvendo as iniciativas e criando novas estruturas de lazer e cultura.

Os municípios localizados ao longo da Rodovia Dutra apresentam os maiores índices de urbanização, em função do grande número de indústrias e dos sistemas de comunicações. Nestes municípios, o processo rápido e intenso de urbanização trouxe como conseqüência imediata o êxodo rural, a desintegração da cultura tradicional e a modificação dos hábitos e costumes da população: habitação, transportes, emprego, educação, saúde, cultura e lazer.

Mas, mesmo assim, resistindo ao progresso e modernização dos costumes, sobrevivem em toda a região, em especial nos municípios fora da Rodovia Dutra, riquíssimas e múltiplas manifestações populares que se encontram na zona rural dos municípios e nos bairros periféricos das cidades industrializadas, apresentando-se por ocasião das festas religiosas e de eventos especiais. Além disso, numerosas instituições culturais se distribuem pela região, abrangendo clubes, centros culturais, grupos cívicos, entidades dedicadas à pesquisa histórica, folclórica e literária, sendo a mais importante delas o Instituto de Estudos Valeparaibanos, sediado em Guaratinguetá.

\subsection{A cidade luizense}

No contexto do Vale do Paraíba, encontra-se a cidade de São Luis do Paraitinga, localizada na Serra do Mar, exatamente à metade do caminho entre Taubaté e Ubatuba, caracterizada, desde os seus tempos de vila, como entreposto de tropeiros. Suas primeiras atividades econômicas estiveram vinculadas à agricultura de subsistência como o feijão, o milho, a mandioca, a 
cana-de-açúcar e o arroz, e mais tarde, a criação de algum tipo de gado leiteiro e de porcos. ${ }^{83}$

Foi fundada oficialmente em 1769, com a nomeação do sesmeiro Manoel Antonio de Carvalho, e em 1773 foi elevada à categoria de Vila, com o estabelecimento do pelourinho. Possuía, nesta época, cinqüenta e duas casas e muitas em construção. Um ano depois o censo revelava uma população de oitocentas pessoas.

Em São Luis do Paraitinga não ocorreu a substituição da cultura da cana-de-açúcar pelo café, como ocorreu em outras regiões da Capitania, por não ter sido invadida pelos canaviais. Sua agricultura estava voltada para a exploração de policultura, inicialmente destinada à subsistência e com o desenvolvimento da produção cafeeira passa a ser destinada ao mercado de exportação.

Já na metade do século XIX, a região de Taubaté e de Guaratinguetá tem a liderança da produção de café e em São Luis do Paraitinga registra-se uma pequena exportação de café e de toucinho. Neste período, iniciam as construções de obras públicas como as construções oficiais da câmara, da cadeia e a nova matriz, levando ao loteamento urbano que vai delinear a atual fisionomia da cidade. ${ }^{84}$

A primeira fábrica que surgiu na cidade data da época do Império, uma fiação instalada numa fazenda no caminho de Ubatuba. As suas atividades agroindustriais foram muito importantes para o desenvolvimento da cidade, limitadas à casa da farinha e à fabricação de aguardente e de rapaduras, que alimentavam um animado comércio de natureza regional.

Em 1920, a cidade chegou a ter 17.870 habitantes, conforme dados apontados pelo comitê Pró-Associação para o Desenvolvimento Cultural e

\footnotetext{
83 "São Luis, o ano inteiro" - publicação do Comitê Pró-Associação para o Desenvolvimento Cultural e Ambiental de São Luis do Paraitinga, p. 14.

${ }^{84}$ São Luis, o ano inteiro" - publicação do Comitê Pró-Associação para o Desenvolvimento Cultural e Ambiental de São Luis do Paraitinga, p. 15.
} 
Ambiental de São Luis do Paraitinga. ${ }^{85}$ A partir de 1930, a pecuária leiteira começou a ganhar importância e hoje constitui, juntamente com uma agricultura de subsistência, a principal atividade econômica do município.

Atualmente, a economia de São Luis do Paraitinga, é ainda baseada na pecuária leiteira além do plantio de eucalipto, bem como no desenvolvimento do turismo que começa a trazer benefícios econômicos para a cidade. De acordo com dados da Fundação SEADE, de 2005, a cidade conta com 10.727 habitantes, sendo que a população urbana é formada por 6.475 habitantes e a rural por 4.252. O decréscimo da população luizense provavelmente decorra de dois aspectos. Na zona rural pela diminuição da economia agrícola, em virtude do plantio do eucalipto. Em entrevistas, esse fato foi citado como uma questão conflitante que vem interferindo na fixação da população na zona rural. Salientou-se também que o fato tem prejudicado a ocorrências das festas tradicionais da roça. Outro aspecto, está relacionado à zona urbana, com população também em declínio, tendo em vista a evasão, especialmente dos jovens, para os grandes centros, em busca de novas oportunidades de estudo e trabalho.

$\mathrm{Na}$ zona rural, as sedes das fazendas Pinheiro e Graminha, com seus sobrados construídos em taipa e pedra, ainda conservados em seus aspectos originais, representam a fase de prosperidade de São Luiz do Paraitinga. A fazenda Pedro Álvares, que melhor simbolizava a expansão econômica rural, não pode mais servir de testemunho desta fase de ouro, pois foi destruída na década de 1950. Algumas estão em péssimo estado de conservação e abandonadas. Outras são abertas à visitação como a Fazenda da Boa Vista e a fazenda Paineiras, nas quais a vida cotidiana daquela época pode ser revivida por meio da presença de senzalas e casas de máquinas.

O que permanece da fase áurea do município, no centro urbano, são heranças que resgatam o cotidiano e a situação econômica daquele tempo. Hoje, esses bens, mesmo que usados para outras finalidades, como casas

${ }^{85}$ Ibid., p. 15. 
comerciais e bancos, continuam como parte integrante da comunidade, ligando o passado ao presente. Por isso, o centro urbano da cidade foi tombado pelo Conselho de Defesa do Patrimônio Histórico, Arqueológico e Turístico do Estado - CONDEPHAAT, em 1977. ${ }^{86}$

Os casarões de taipa, com sacadas, janelas tipo guilhotinas e portas com bandeiras de ferro trabalhado, representam o modo de vida dos moradores mais ricos de São Luis do Paraitinga no século XIX, que reproduziam os modelos do Rio de Janeiro e de Minas Gerais. Situados principalmente na Praça Oswaldo Cruz e ruas adjacentes, os casarões contrastam com as casas térreas da Rua do Carvalho, feitas em taipa ou paua-pique onde, na época de sua construção, viviam as famílias menos abastadas, ferreiros e pequenos comerciantes, cujas atividades dependiam do movimento das tropas. Hoje, é nesta praça que acontecem as principais manifestações culturais da cidade.

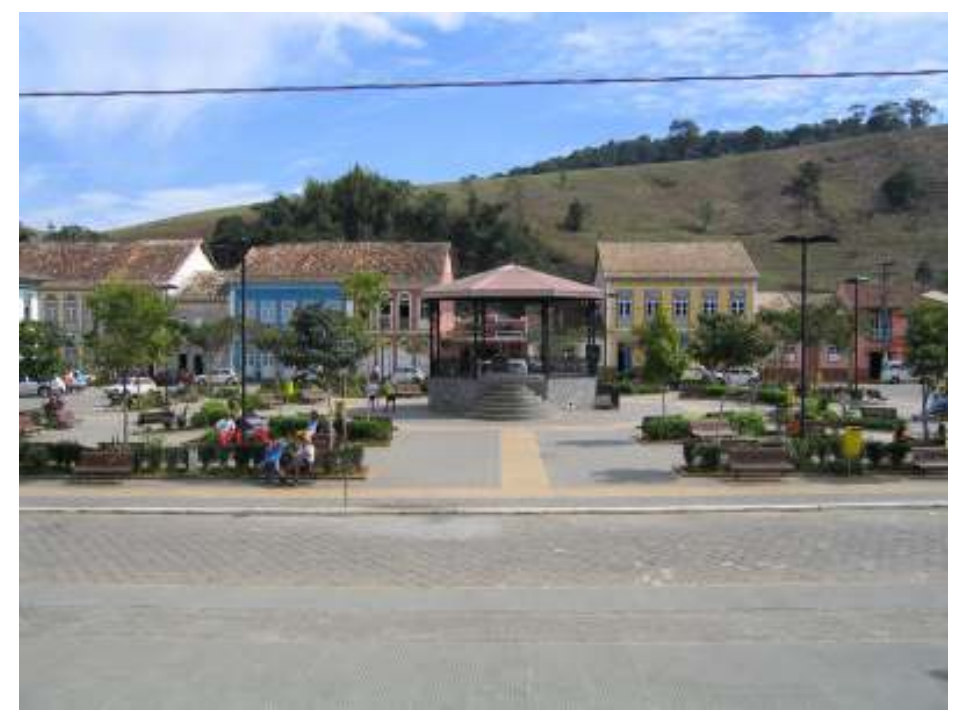

Praça Oswaldo Cruz. Foto de Rosana Beneton.

Outros locais históricos importantes são o antigo Museu Oswaldo Cruz, hoje reinaugurado como Centro Cultural, e o prédio da Prefeitura.

\footnotetext{
${ }^{86}$ São Luis, o ano inteiro" - publicação do Comitê Pró-Associação para o Desenvolvimento Cultural e Ambiental de São Luis do Paraitinga, p.16.
} 


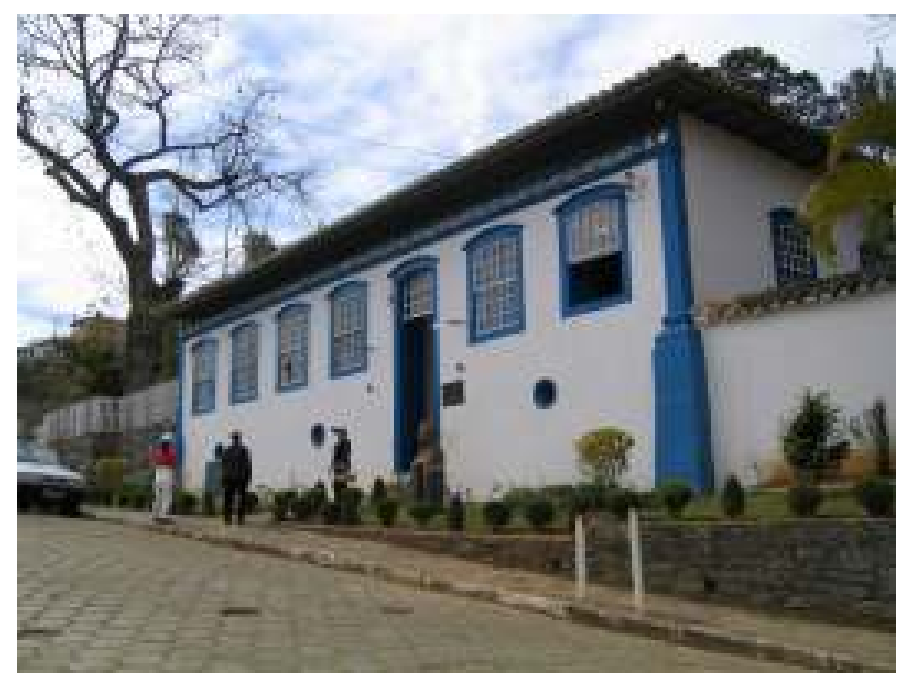

Museu e Centro Cultural Oswaldo Cruz. Foto de Rosana Beneton.

O Centro Cultural foi a casa onde nasceu o médico sanitarista Oswaldo Cruz, construída em taipa de pilão e pau-a-pique. Oswaldo Cruz residiu em São Luis do Paraitinga apenas na primeira fase de sua infância, pois sua família transferiu-se para o Rio de Janeiro.

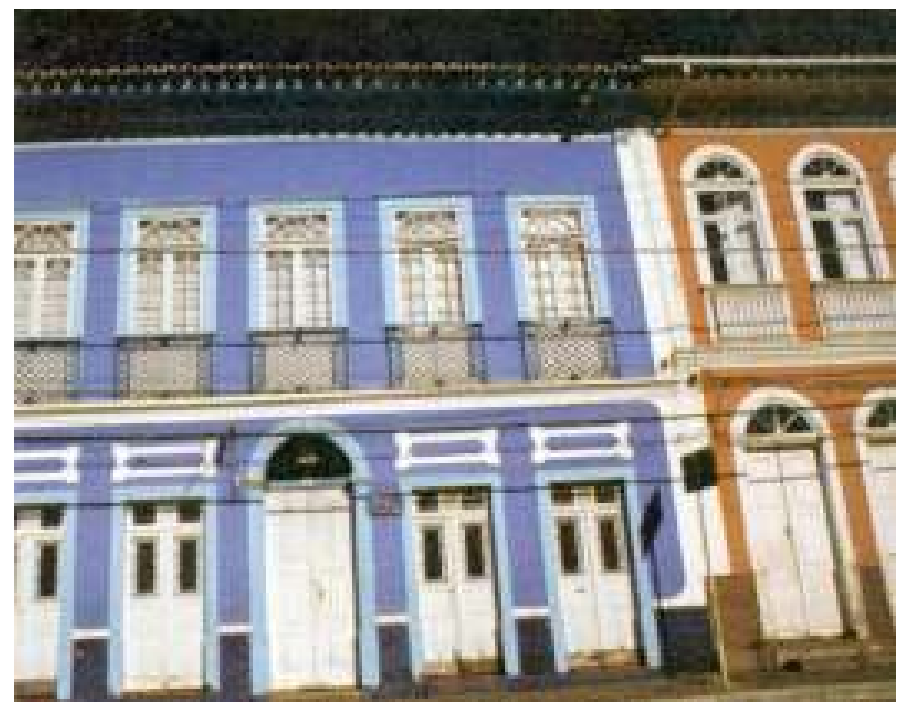

Prefeitura Municipal de São Luis do Paraitinga. Foto de Rosana Beneton.

O prédio da atual Prefeitura foi uma residência construída no século XIX, com técnica semelhante à da casa de Oswaldo Cruz. 
O Mercado Municipal foi reformado em 1902, substituindo um prédio antigo e mostra o feitio das construções públicas do início do século XX, e além dos alimentos e produtos de artesanato que oferece, é um marco na paisagem da cidade.

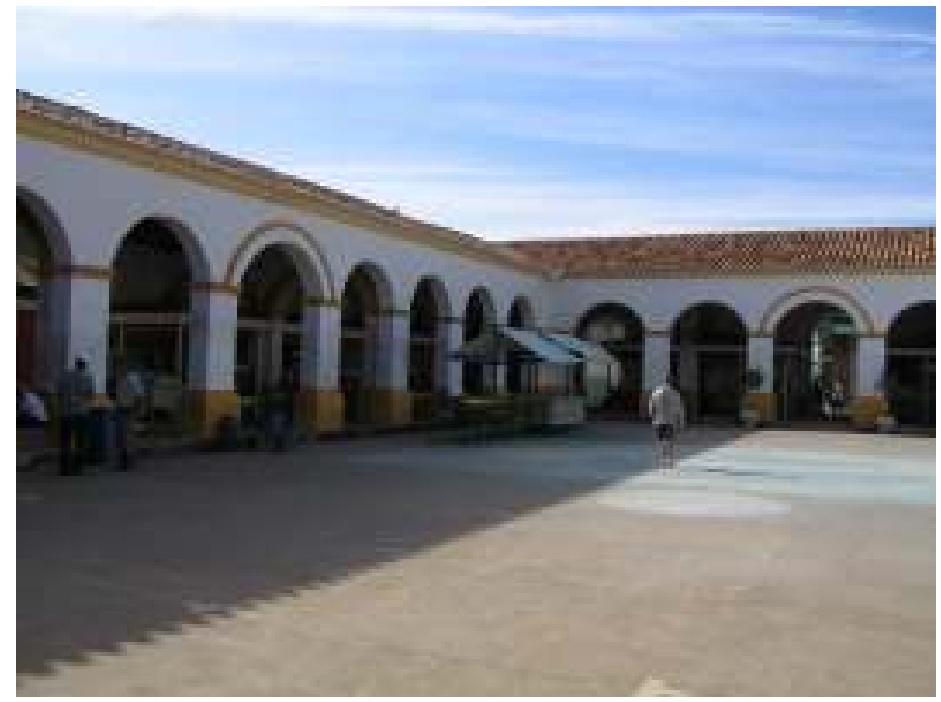

Mercado Municipal. Foto de Rosana Beneton.

As igrejas da cidade representam o testemunho da presença da tradição católica e a importância da religião e de seu poder na vida da cidade, entre elas, destacam-se a Igreja das Mercês, a Igreja do Rosário e a Igreja da Matriz.

A Igreja das Mercês, construída nos fins do século XVIII, é uma das primeiras edificações da cidade e suas paredes estruturais permanecem em taipa-de-pilão. A ladeira das Mercês é composta por pedras retiradas do Rio Paraitinga, feita pelos escravos. Na ladeira estão instalados um painel em azulejo e o Chafariz que integram o Projeto Resgate da Memória. ${ }^{87}$

A Igreja do Rosário foi construída no século XIX e edificada em estilo eclético, predominando o gótico decadente. Foi feita em taipa sobre alicerce de pedras da região, com relevo frontal em barro, com a Virgem Maria oferecendo o rosário a São Domingos. Na lateral direita, a Igreja é cercada por muro de pedras construído por escravos. Hoje compõem o Largo do Rosário uma praça e um chafariz, com monumento em homenagem ao Teatro. ${ }^{88}$

\footnotetext{
${ }^{87}$ São Luis, o ano inteiro" - publicação do Comitê Pró-Associação para o Desenvolvimento Cultural e Ambiental de São Luis do Paraitinga, p. 41.

${ }_{88}$ Ibid., p.42.
} 


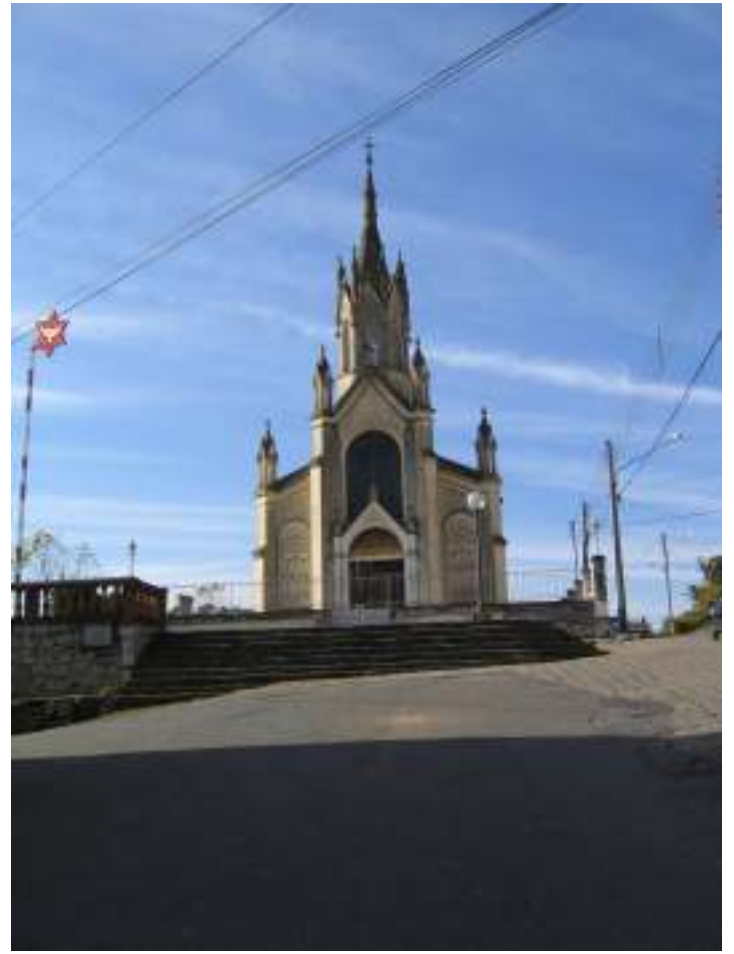

Igreja do Rosário. Foto de Rosana Beneton.

A Igreja da Matriz, localizada na Praça Oswaldo Cruz, no centro da cidade, é dedicada a São Luiz de Tolosa, santo padroeiro da cidade. Foi construída no século XIX e possui vários altares em mármore de Carrara.

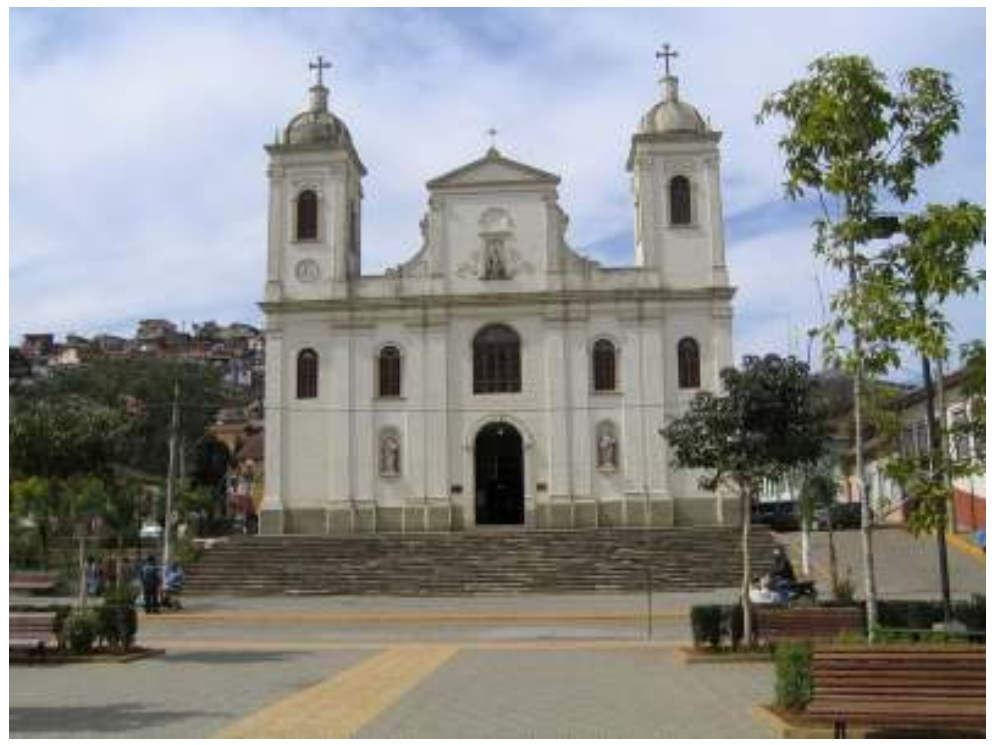

Igreja da Matriz. Foto de Rosana Beneton. 
Nestas igrejas o povo ainda se reúne para os tradicionais festejos que já se realizavam no tempo da Colônia e do Império. Mas, é na Praça da Igreja da Matriz que acontecem as principais manifestações culturais da cidade, atraindo turistas e pesquisadores.

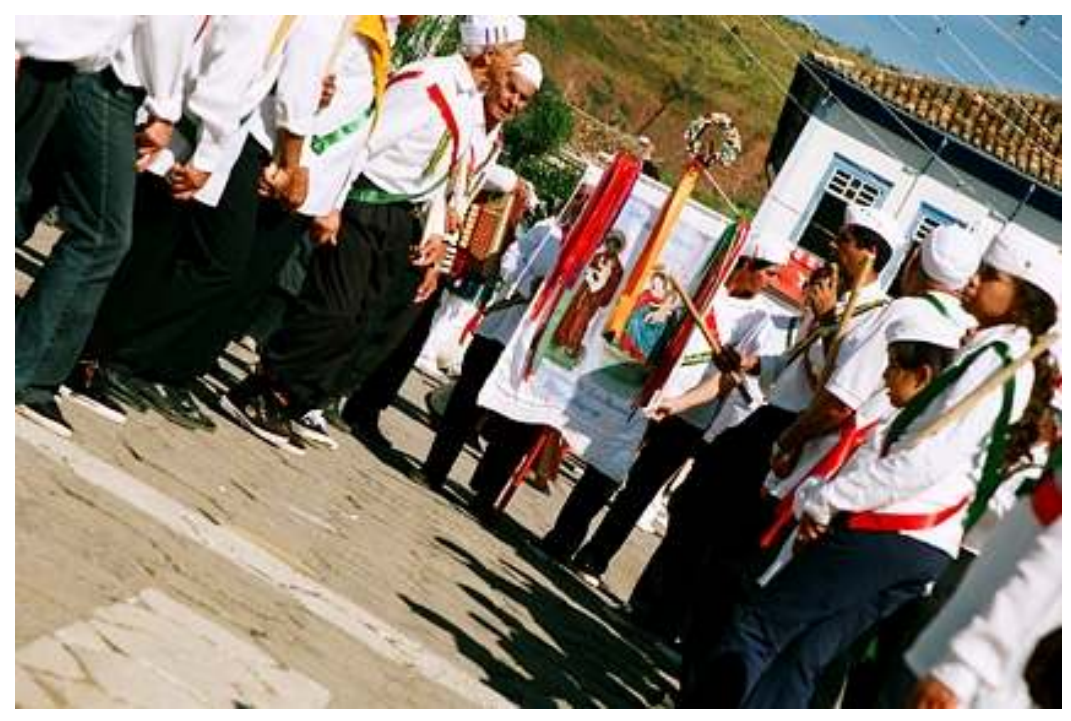

Festa do Divino Espírito Santo. Foto de Daniella Giannini

\subsection{As celebrações coletivas do Vale do Paraíba}

A questão da tradição festeira da cidade de São Luis do Paraitinga, no contexto do Vale do Paraíba, é primordial para se pensar as relações da Rádio Paraitinga com as produções simbólicas da cidade, bem como os fatores históricos que dão conformidade a atual configuração sócio-cultural e econômica que lhe deram causa.

As cidades do Vale do Paraíba nasceram sob o signo de padroeiras e padroeiros, e assim, logo se tornou um Vale festeiro, como comenta Francisco Sodero Toledo. ${ }^{89}$ Há quase 400 anos, ladainhas, novenas e procissões movimentam e povoam capelas, igrejas, ruas e praças, reunindo o povo em torno de festas em louvor a antigas devoções ou em torno de novas atrações.

${ }^{89}$ Sodero Toledo Serviços Educacionais S/C - http://valedoparaiba.com acesso em 12/07/2006 
Nas cidades e vilas do Vale, bem como nas zonas rurais, os compromissos e os negócios se regem, pelo "tempo das festas". Tudo acontece "antes da festa" ou "depois da festa", principalmente quando se trata dos grandes eventos, como Festa de São Benedito, padroeiro dos escravos. As festas em seu louvor são realizadas em toda a região, mantendo tradições, usos e costumes; da Semana Santa, com suas solenidades, procissões, matracas, imagens antigas e comidas típicas como a bacalhoada, a paçoca de amendoim e o pinhão; as Festas do Divino Espírito Santo, vindas da terra lusa; as Festas de Tropeiro, com culinária típica e desfile de tropas autênticas e outras comemorações como o Ano Bom, o Natal, e algumas festas de santos padroeiros e festas profanas como o Carnaval.

Como observa o autor, a festa se tornou uma instituição que se integra até no linguajar do valeparaibano e para ele:

\footnotetext{
"...Todos concordam que "o melhor da festa é esperar por ela", mesmo sabendo que "em festa de jacu, inhambu não entra".

Ainda que você seja "peru de festa", sabe que "em festa e batizado só vá se for convidado". É certo que "quem convida dá banquete", mas não podemos esquecer que "pela festa se conhece o festeiro", sempre chegando o momento em que "festas acabadas, músicos a pé". 90
}

As festas tradicionais de cada município do Vale do Paraíba tiveram origem com o desenvolvimento da religiosidade popular católica vivida, dominantemente, pelos pobres em geral e marcada pela presença do misticismo sertanejo, do culto mariano e pelo tempo de festas, para saudar, pedir proteção e revigorar a crença no "seu santo".

Sodero, recompondo os aspectos históricos, convida a penetrar na essência que leva ao conhecimento das relações que se estabeleceram entre a verve festeira da região com seus aspectos religiosos, com os ciclos naturais e com a economia. Desta forma, entrelaça as três instâncias, buscando a realidade sócio-cultural diante da história, mais precisamente no século XIX, quando o catolicismo popular foi se deslocando, gradativamente, da zona rural

\footnotetext{
${ }^{90}$ Sodero Toledo Serviços Educacionais S/C - http://valedoparaiba.com acesso em 12/07/2006.
} 
para os centros urbanos, sem apresentar grandes alterações nas suas características básicas.

As festas eram ajustadas ao ciclo litúrgico e ao mesmo tempo, ao ciclo da vida natural, marcadas pela influência da economia cafeeira, com destaque para as festas religiosas desenvolvidas entre os meses de abril a agosto, que corresponde ao período da colheita, preparo e venda dos grãos. Hoje, realizam-se neste período as festas de São Benedito, as festas Juninas, do Divino Espírito Santo e as mais tradicionais, durante o mês de agosto, como a de Bom Jesus, em Tremembé e a de Nossa Senhora da Piedade, em Lorena.

As festas valeparaibanas caracterizam-se pelo seu caráter religioso e profano. São momentos de grande demonstração de fé e representam para o povo a esperança, a participação e a garantia da proteção especial de Deus, dos santos e da Virgem Maria. São também ocasiões de diversão, marcadas por expressões de alegria, pela descontração popular, manifestadas nas ladainhas, novenas, procissões, com muita música e queima de fogos e onde se manifestam as bandas de músicas, os grupos de violeiros, leiloeiros, cavalgadas, e tantos outros grupos festeiros que animam a região. Como afirma Sodero:

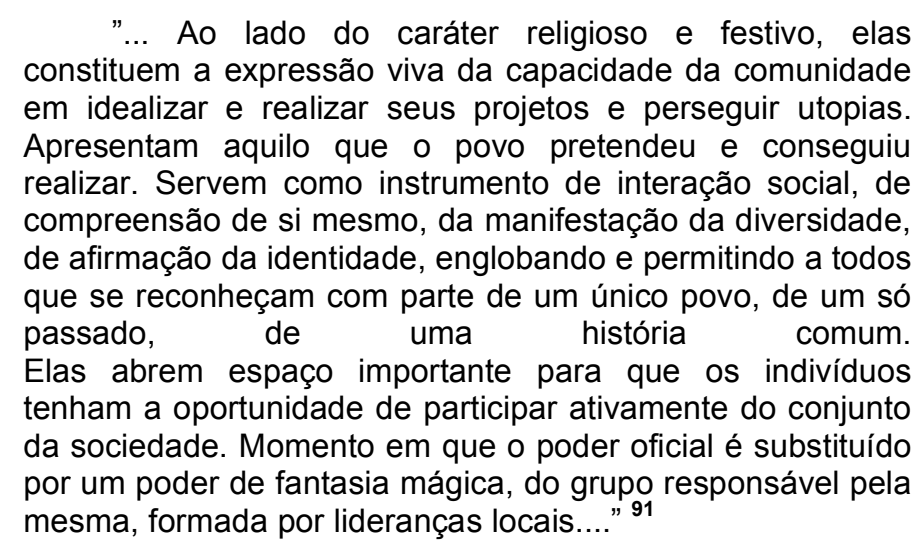

É a ritualização da tradição, que é própria da memória coletiva popular, próxima do mito que se manifesta ritualmente, encarnado pelo grupo restrito, como vimos com Renato Ortiz, e que deve se transformar em vivências, realizadas no cotidiano, assegurando sua perenidade, enquanto que a memória

${ }^{91}$ Sodero Toledo Serviços Educacionais S/C - http://valedoparaiba.com acesso em 12/07/2006. 
nacional se refere a uma história que transcende os sujeitos e não se concretiza imediatamente no cotidiano, situando-se em outro nível, vinculandose no domínio da ideologia.

Esta memória popular da região tem um forte apelo para o momento da refeição comunitária, costume que se mantém nas festas juninas, de São Benedito, com farta distribuição de comida e doces para o povo, revelando o caráter hospitaleiro e pródigo do homem valeparaibano. Estas manifestações solidárias representam não só o momento da partilha, mas da igualdade, da aproximação de todos, como parte de um mesmo grupo, de um mesmo destino, desejosos de um futuro.

As festas representam também o momento de manifestação artística e estética, construindo espacialidades, nas quais as pessoas expressam a sua capacidade inventiva, criativa e espontânea, como diz Milton Santos, reveladoras de aspectos significativos da identidade cultural do grupo social.

As festas religiosas e profanas continuam representando esperança, apontando possibilidades de participação e realização social, propiciando momentos de alegria, que como foi visto com Muniz Sodré, acontece onde a vida possa afinar-se ludicamente com o mundo em suas manifestações espontâneas, emergindo como a ponta extrema dessa celebração coletiva, "sem pecado, sem perdão e sem submissão".

Desta forma, a Rádio Paraitinga concorre com processos comunicacionais nascidos das manifestações autênticas que permeiam historicamente a vida das comunidades da região, e deve procurar caminhos para se integrar e para interagir como ator nesses processos.

\subsection{São Luis do Paraitinga, lugar de festa o ano inteiro}


Em compasso com o Vale do Paraíba festeiro, na cidade de São Luis do Paraitinga, as festas populares e as tradições religiosas também foram preservadas. É considerada a cidade mais festeira da região, com um vasto calendário festivo de janeiro a janeiro, preparado e vivido intensamente pelos seus habitantes.

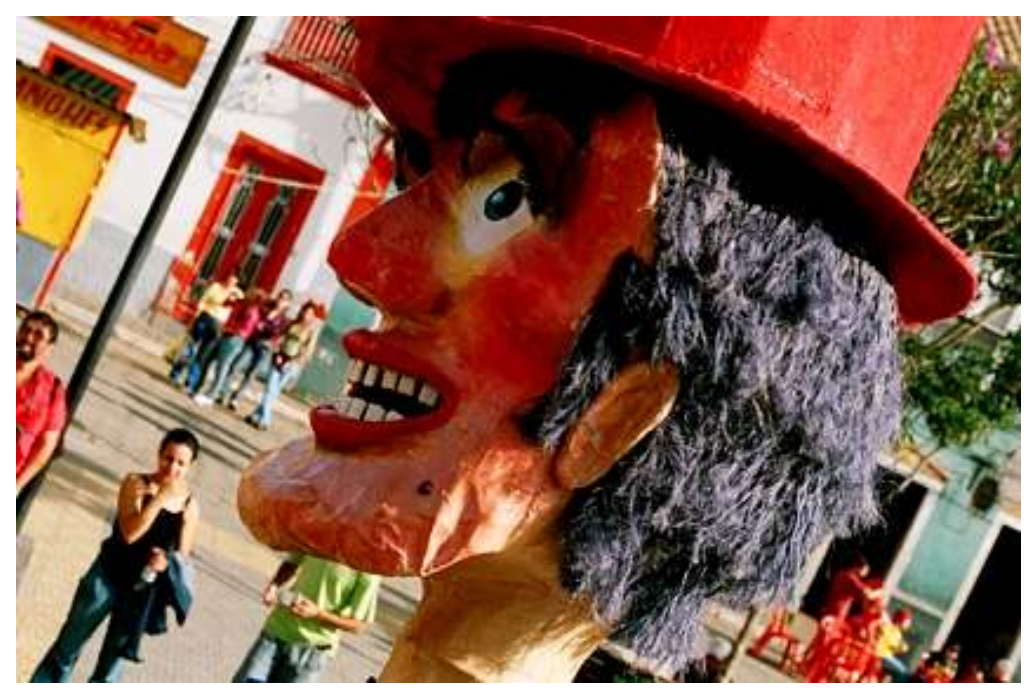

Boneco Gigante João Paulino. Foto de Daniella Giannini

O casal de bonecos gigantes, feitos de papel machê e de taquara, João Paulino e Maria Angu, há mais de meio século anuncia todas as festas, como uma espécie de abre-alas para as comemorações. Os bonecos são seguidos pela cidade toda, por muitas crianças, provocando algazarras e brincadeiras, conquistando a simpatia de todos e dando o tom do espírito festivo da cidade. Eles também encerram apoteoticamente cada festa, deixando um gostinho renovador para o próximo festejo.

As comemorações mais conhecidas são A Festa do Divino Espírito Santo e o Carnaval, precedido pelo Festival de Marchinhas Carnavalescas. A festa do Divino Espírito Santo é uma festa secular, tendo sua origem na cidade no século XIX, trazida pelos portugueses, mantendo uma relação estreita com o ciclo agrícola, realizada, portanto, bem próxima às colheitas do inverno, o que a caracteriza como uma festa de consumo, realizada em 
junho. ${ }^{92}$ Esta festa se tornou um grande atrativo para pesquisadores e sociólogos, pois porta em seu significado muitas relíquias culturais, elementos importantes para a preservação das tradições. Acontece com uma grandiosa procissão: a Folia do Divino.

Os festeiros são escolhidos através de sorteio e iniciam a Festa com a distribuição do "afogado", comida típica, que representa as manifestações solidárias, não só do momento da partilha, mas da igualdade, da aproximação de todos, como foi visto com Sodero. A festa é multiplicada com a apresentação da Cavalhada - teatro eqüestre da idade média, representando a luta entre mouros e cristãos, que se encerra com a conversão dos mouros em cristãos. ${ }^{93}$ Outras manifestações se desenrolam como a Congada, o Moçambique, o Jongo, Dança do Sabão, Dança de Fitas, etc., tornando a Praça da Matriz um palco colorido de bandeiras e de trajes, ritmados pela polifonia dos cantantes e pela graça de seus dançarinos.

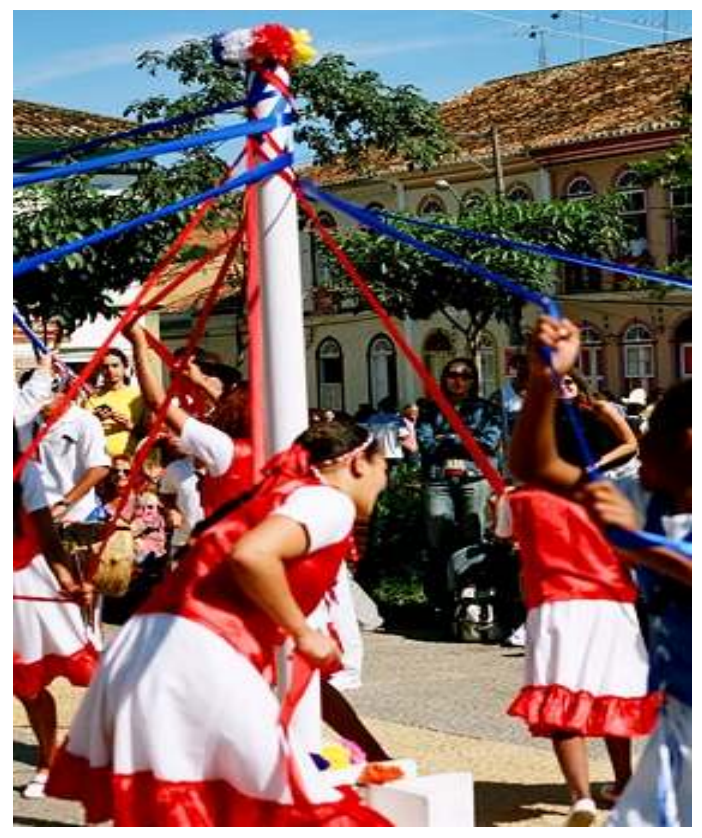

Dança de Fitas. Foto de Daniella Giannini

\footnotetext{
92 São Luis, o ano inteiro" - publicação do Comitê Pró-Associação para o Desenvolvimento Cultural e Ambiental de São Luis do Paraitinga, p. 65.

93 Ibid., p.66.
} 


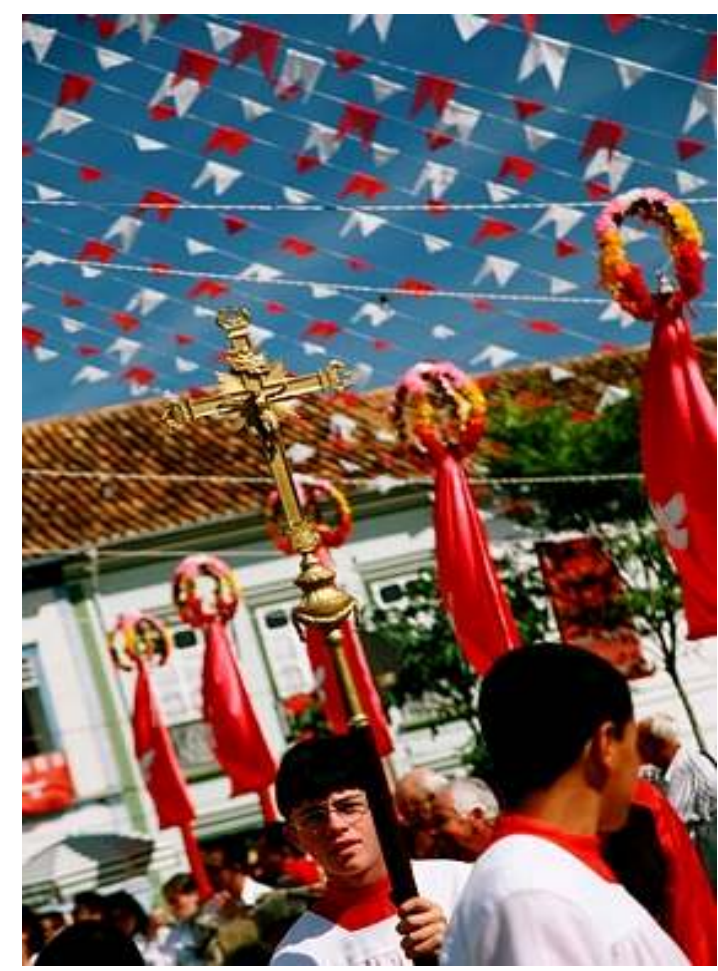

Encontro de Bandeiras do Divino. Foto de Daniella Giannini.

O Carnaval da cidade se transformou, nos últimos dez anos, em um dos carnavais mais originais do Estado de São Paulo, com ampla divulgação da mídia nacional.É concebido na cultura do povo luizense, por meio dos mitos e das lendas que povoam o lugar, ilustrado com a tradição dos bonecos gigantes, cujos corpos são produzidos por balaios de taquara poca ${ }^{94}$ e os cabeções por papel machê. Estes bonecos resgatam as figuras de poetas, músicos e de personalidades que fizeram histórias no cotidiano, dentro de uma concepção pura, ingênua e de um misticismo religioso.

\footnotetext{
${ }^{94}$ Espécie de bambu de pouco valor comercial, www.tvcultura.com.br/reportereco/materia.asp?materiaid=264, matéria de 24/7/05 acesso em 26/10/06
} 


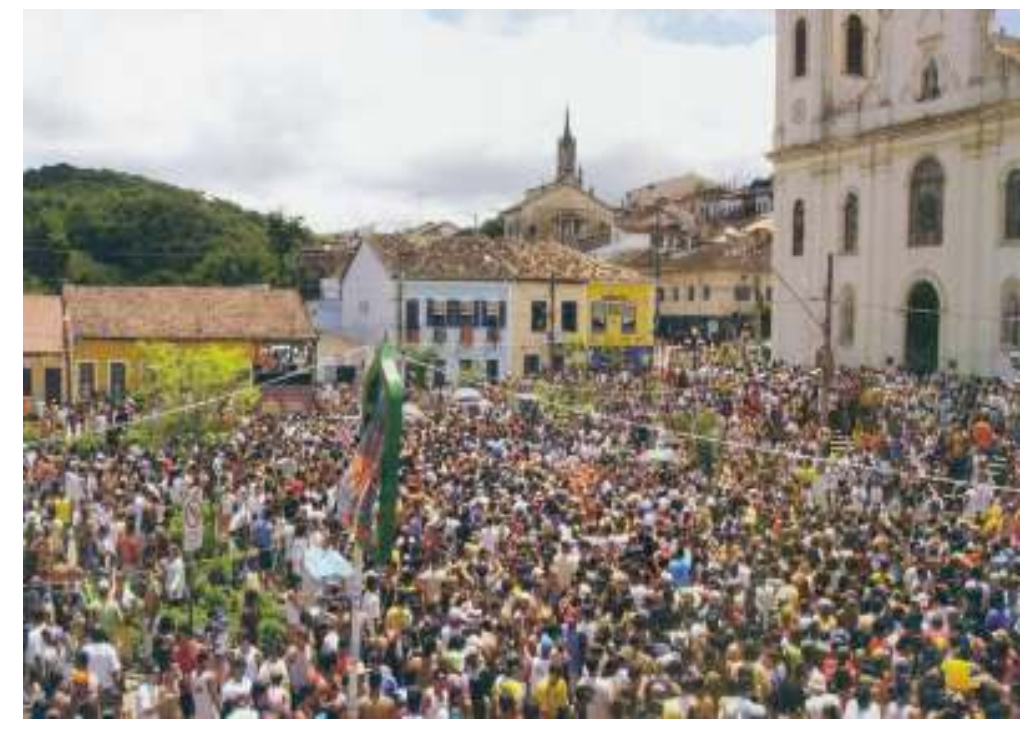

Carnaval na Praça Oswaldo Cruz. Foto scaneada do folheto do Comtur.

Diversos blocos percorrem as ruas estreitas da cidade, contagiando a população de alegria e de humor, entre os mais famosos estão: Encuca a Cuca, Juca Teles do Sertão das Cotias, Pé na Cova, Bloco do Lençol, Pai do Troço, Rua Nova, Espanta Vaca, Pique das Trais e outros, regados pelo som das marchinhas, que asseguram a fama de Terra dos Músicos, conferida à cidade.

O Festival de Marchinhas Carnavalescas restitui à cidade sua cultura musical e vem valorizando as produções e os músicos locais. As marchinhas são caracterizadas por uma linguagem própria, por uma musicalidade original, que revelam a criatividade e a espontaneidade de seus habitantes. O festival convoca os músicos da cidade, porém, também é aberto para compositores da região, cativando um número cada vez maior de participantes de outros centros que estão se adaptando à musicalidade da cidade e imprimindo ao Festival uma dimensão cada vez mais forte. ${ }^{95}$

O Festival vem tirando muitos talentos do anonimato, fortalecendo o gosto pela música enquanto linha simples, que vai ao encontro do gosto popular. Cada Festival reúne mais de 100 composições inscritas, que passam

\footnotetext{
${ }^{95}$ São Luis, o ano inteiro" - publicação do Comitê Pró-Associação para o Desenvolvimento Cultural e Ambiental de São Luis do Paraitinga, p.61.
} 
por um processo seletivo, apresentadas no Ginásio Poliesportivo, durante dois fins de semana do mês de janeiro, com a participação de mais de 3.000 pessoas, resultando em 24 compositores selecionados. ${ }^{96}$ Estas marchinhas serão aquelas que animarão o carnaval do ano na cidade e que serão cantadas e valorizadas pelos foliões vindos das mais diversas regiões do Estado.

Além disto, na zona urbana acontecem: em janeiro, a Festa de São Sebastião; da Semana Santa em data móvel; de São Benedito, comemorado logo após o domingo de Páscoa; Festa Agropecuária em julho; Festa de São Luiz de Tolosa em agosto; da Nossa Senhora das Mercês em julho e setembro; o Dia do Saci, em outubro e os Presépios e Pastoras em dezembro.

As festas rurais, ainda pouco exploradas pelos turistas e pouco investigadas pelos pesquisadores, podem ser consideradas de resistência, e oferecem um fértil campo para pesquisas, que motivam esta pesquisadora para estudos posteriores. São elas: Santa Cruz em maio; Santo Antonio, São João e São Pedro em junho; São Roque em agosto; Nossa Senhora Aparecida da Capela do Alto, em setembro; Nossa Senhora de Brotas, em outubro e de Santa Cecília, em novembro.

O artesanato de São Luis do Paraitinga é conhecido pela cerâmica, na forma utilitária ou decorativa, que guarda a herança legada pelos indígenas na produção de potes, de moringas para armazenar água, de vasos e de imagens de santos, de animais e de figuras típicas do cotidiano luizense.

Outros tipos de artesanato produzidos pelas mãos talentosas dos artesãos, são as gamelas, os pilões, os monjolos, os pequenos engenhos de moer cana, os oratórios, as esculturas religiosas e lúdicas, os instrumentos como violas e rebecas, feitos em madeira, matéria-prima abundante, principalmente na região serrana do município.

\footnotetext{
96 Ibid., p. 61.
} 
Também, em quase todo o município, são produzidas cestarias ou trançados, como os balaios, os cestos e os jacás - cestos para conduzir carga às costas de animais, peças imprescindíveis na vida doméstica da zona rural. $\mathrm{O}$ artesanato em taboa - planta de caule fino, mas resistente, encontrada nos brejos do município - produz tapetes, redes e esteiras. São tradicionais o bordado, o tricô e o crochê, assim como a produção de bonecas de pano e palha. A pintura do lugar observa um estilo primitivista, reproduzido em telas por paisagens bucólicas e cenas da rotina local. ${ }^{97}$

Diante desta rica e diversificada cultura, com intensa participação popular, como a Rádio Paraitinga pode estabelecer um processo comunicacional, em comunhão com a concepção de vida, dos valores éticos, estéticos, artísticos e religiosos da comunidade? Como a Rádio Paraitinga compreende, participa e desenvolve os laços de identidade e de pertencimento? Como a comunidade se identifica com a Rádio? Como vinculam sua intensa vivência do cotidiano a Rádio?

\footnotetext{
${ }^{97}$ São Luis, o ano inteiro" - publicação do Comitê Pró-Associação para o Desenvolvimento Cultural e Ambiental de São Luis do Paraitinga, p.73.
} 


\title{
Capítulo 4
}

\section{A Rádio Paraitinga e as relações com as manifestações culturais da cidade}

4. A Rádio Paraitinga e as relações com as manifestações culturais da cidade

\author{
"Fala (a rádio Paraitinga) bem da nossa cidade, é importante \\ para a cidade, porque é a nossa 'radinha'." \\ Moradora de São Luis do Paraitinga
}

\begin{abstract}
Como já está posto nos capítulos anteriores a radiodifusão, e particularmente as emissoras de baixa potência, podem desempenhar
\end{abstract}


importante papel nas comunidades onde estão inseridas. As possibilidades de sua contribuição para o desenvolvimento social passam por várias instâncias e há poucas pesquisas no Brasil que relatam experiências com as rádios comunitárias.

É certo que a rádio comunitária pode constituir-se num dos meios populares de comunicação que contribuem para o desenvolvimento de cidadãos e suas comunidades, não só do ponto de vista econômico, mas também para o crescimento cultural.

Este é o foco principal desta dissertação e neste capítulo tratar-se-á da análise dos resultados obtidos com a aplicação das técnicas adotadas para o levantamento dos dados que permitiram conhecer melhor o objeto de estudo e articulá-los ao referencial teórico escolhido. Essa análise buscará atender aos objetivos específicos propostos nesta dissertação.

\subsection{Apresentação do Trabalho de Campo}

A concepção metodológica utilizada neste trabalho permitiu articular conceitos a partir dos dados obtidos por diferentes técnicas. O quadro teórico sinalizou diretrizes e orientação para os caminhos de reflexão da dissertação. A combinação entre a revisão teórica, a pesquisa histórica, as ações exploratórias e o processo de observação resultaram em importantes indicadores que dirigiram a pesquisa empírica, cujo trabalho de campo implicou na obtenção de dados quantitativos reveladores. Estes puderam ser enriquecidos com os dados qualitativos, oriundos das entrevistas e dos depoimentos espontâneos dos pesquisados. De volta ao referencial teórico, a dialética estabelecida entre os dados permitiu uma reflexão analítica sobre o objeto de estudo e, a partir dela, foram elaboradas considerações e novos questionamentos, num processo de interpretação criativa.

Os métodos e técnicas implicaram, inicialmente, na utilização de ações exploratórias, tais como contatos telefônicos e visitas à cidade, durante os 
meses de maio e junho. Nessas visitas foram contatadas pessoas da comunidade, algumas delas envolvidas com as questões e atividades culturais, tais como o Diretor de Cultura da Prefeitura, Benedito Galvão Frade Jr.; o Diretor de Turismo da Prefeitura, responsável pelo Comtur - Conselho Municipal de Turismo, Eduardo Valente Junior; o Presidente da AACULT Associação de Ação Cultural para Apoio às Manifestações Culturais, Amarildo Ribeiro; outras envolvidas com as questões de comunicação, como o Diretor da Rádio Paraitinga, André Luis Bilard; a locutora da emissora Angélica; as atendentes do PIT - Posto de Informação Turística do Comtur, Natália e Danielle; além de lojistas, estudantes e cidadãos comuns, que transitavam pelas ruas da cidade nos dias visitados.

Outros contatos completaram as entrevistas com os atores culturais da cidade. Cinco delas foram com locutores da Rádio Paraitinga e, também com Dona Cinira, viúva de Elpídio dos Santos, importante representante da música local e compositor de todas as músicas dos filmes de Mazzaropi. Ela e a família ainda hoje são referência quando a mídia busca as tradições musicais da cidade.

Os dados levantados nessas ações exploratórias revelaram que a cidade não dispunha de nenhum jornal. Por meio de depoimentos de alguns dos entrevistados, no ano de 2005, por iniciativa de um estudante não identificado, foram impressos três números de um jornal que trazia notícias da cidade, críticas à situação política e algumas matérias de cultura. O jornal foi impresso com recursos próprios e distribuído gratuitamente nos pontos de grande circulação da cidade, bares, restaurantes e no Posto de Informações Turísticas. Soube-se que, dadas as dificuldades para mantê-lo sem ajuda financeira, o responsável pelo jornal descontinuou sua impressão. Infelizmente não foi possível conhecer qualquer exemplar desse jornal.

A fase exploratória também indicou possibilidades de realização do trabalho de campo. Desta forma, para a pesquisa empírica, foi elaborado um formulário para aplicação-teste, anexo II. Dez pessoas participaram desse teste, aplicado em 12 de julho de 2006, pela própria pesquisadora, sendo: 5 
mulheres - 3 com idade entre 15 e 25 anos, 1 entre 26 e 45 anos e 1 com mais de 45 anos e 5 homens - da mesma forma, 3 com idade entre 15 e 25 anos, 1 entre 26 e 25 anos e 1 com mais de 45 anos de idade.

O instrumento utilizado mostrou-se eficaz para a busca de dados, embora algumas alterações fossem necessárias para aprimorar o entendimento do pesquisado, a coleta e posterior tabulação de dados. Reelaborado, o formulário passou por uma validação sociolingüística de Célia Maria Escanfela, professora de português, com experiência em validações do gênero. Foi também avaliado e recomendado por um pesquisador da Fundação SEADE ${ }^{98}$, Renato Sérgio de Lima, como uma das técnicas indicadas para este trabalho. Optou-se pela aplicação do formulário, preenchido pela pesquisadora e seus colaboradores, que funcionou como guia de entrevistas, porque a coleta exigia garantia de entendimento das questões e acerto na marcação das opções apresentadas, bem como anotações de respostas às questões abertas e bom registro das citações espontâneas.

O formulário final, anexo III, foi aplicado, seguindo a metodologia da amostragem aleatória, nos dias 21 de julho e 12 de agosto de 2006 a 83 moradores da cidade pela pesquisadora e três colaboradores previamente treinados. Foi escolhida a técnica da Amostragem por Acessibilidade ou por Conveniência que, embora destituída de rigor estatístico, é recomendada para estudos qualitativos, conforme Antonio Carlos Gil. ${ }^{99}$

Para delimitar a área na qual os pesquisados seriam procurados, dividiuse a zona urbana da cidade em cinco subáreas, conforme mostra o anexo IV. A quantidade de ruas da zona urbana permitiu cobri-la quase que por completo. A orientação aos aplicadores do formulário foi de que deveriam abordar as casas de cada rua com intervalo de três casas.

A tabulação dos dados, anexo $\mathrm{V}$, foi submetida à apreciação de uma profissional em estatística, da Fundação SEADE, Eliana Bordini, para

\footnotetext{
${ }^{98}$ Fundação Sistema Estadual de Análise de Dados, Governo do Estado de São Paulo.

${ }^{99}$ Métodos e Técnicas de Pesquisa Social, p. 104.
} 
recomendações quanto ao uso dos resultados junto aos demais dados, obtidos por outras técnicas, em especial os dados qualitativos.

De acordo com dados de 2005, da Fundação SEADE, a cidade de São Luis do Paraitinga conta com 10.727 habitantes, sendo 6.475 moradores da zona urbana e 4.252 da zona rural. Selecionou-se a população urbana, representativa de $60 \%$ da população luizense para objeto de estudo desta dissertação. ${ }^{100}$ Responderam à entrevista, 83 moradores o que corresponde a $1,28 \%$ da população urbana.

Assim, participaram:

48 mulheres - 12 entre 15 e 25 anos; 25 entre 26 e 45 anos e 11 com mais de 45 anos, e 35 homens - 16 entre 15 e 25 anos; 12 entre 26 e 45 anos e 07 com mais de 45 anos.

Identificação da amostra do formulário

\begin{tabular}{|l|c|c|c|c|c|}
\hline \multirow{2}{*}{ SEXO } & \multirow{2}{*}{$\mathbf{N}^{\circ}$} & \multicolumn{5}{|c|}{ FAIXA ETÁRIA } \\
\cline { 3 - 6 } & & $\begin{array}{l}15 \text { a } \\
\text { anos }\end{array}$ & $\begin{array}{l}26 \quad \text { a } \\
\text { anos }\end{array}$ & $\begin{array}{l}\text { mais de } \\
\text { anos }\end{array}$ \\
\hline Feminino & 48 & 12 & 25 & 11 \\
\hline Masculino & 35 & 16 & 12 & 07 \\
\hline Total & 83 & 28 & 37 & 18 \\
\hline
\end{tabular}

O cuidado de se identificar o gênero e, dentro dele, a faixa etária dos pesquisados, teve o intuito de averiguar se haveria diferença significativa entre os dados que seriam obtidos, considerando as características que envolvem cada uma dessas classes.

No entanto, não se verificou diferenças significativas entre as respostas dos homens e das mulheres. Já com relação às diferentes faixas etárias, notou-se que, para algumas perguntas, as respostas dos mais jovens, de 15 a 25 anos, mostraram algumas discrepâncias que serão apontadas no decorrer do texto quando se apresentarem significativas.

\footnotetext{
${ }^{100}$ http://www.seade.gov.br acesso em 19/06/2006
} 
Foram poucas as dificuldades encontradas para aplicação do formulário, no entanto, registra-se:

- por tratar-se de dias úteis, algumas casas não atenderam à porta, provavelmente porque seus moradores deveriam estar no trabalho ou na escola;

- a maioria dos pesquisados foram do sexo feminino, conforme mostra a somatória dos pesquisados por gênero, ou seja, 48 mulheres e 35 homens, no entanto, este fato por si só não interferiu no resultado obtido. Porém a pesquisadora procurou completar a pesquisa, no segundo dia de aplicação, buscando moradores do sexo masculino para equilibrar a amostra.

Para levantamento de dados através das entrevistas, as dificuldades encontradas foram:

- alguns atores das ações culturais da cidade se mostraram reticentes nas respostas ou mostraram-se temerosos em emitir opinião sobre as ações que são engendradas para a organização, divulgação e realização das festas tradicionais;

- dois locutores não tiveram disponibilidade de tempo para participar da entrevista;

- os contatos mantidos com o diretor da emissora, André Luis Bilard, apesar de muito cordiais desde o início, na fase exploratória, foram difíceis posteriormente para o confirmação de dados sobre a história da rádio. Acredita-se que o fato de dirigir a emissora de fato, mas não de direito (ocupa cargo político, é vereador), o tenha deixado receoso das repercussões que as revelações de alguns fatos pudessem ter.

\subsection{Identificação das manifestações culturais da cidade}

Para buscar subsídios objetivando identificar as principais manifestações culturais da cidade com vistas a compreender os valores amalgamados na identidade ou imaginário cultural da comunidade, o formulário apresentou 
perguntas sobre as festas tradicionais que acontecem na cidade, cujos dados foram colhidos na fase exploratória e que constam do calendário oficial da cidade, divulgado pela Prefeitura Municipal.

Esses dados confirmam os estudos de Pazin e Sodero expostos no capítulo 3, pelos quais se compreende a tradição festeira do Vale, em especial, a cidade de São Luis do Paraitinga, considerada a mais festeira da região, configurada pela origem sagrada, sob o signo de padroeiros e padroeiras, onde há quatrocentos anos movimentam e povoam capelas, igrejas, ruas e praças, reunindo o povo em torno de festas em louvor a antigas devoções ou em torno de novas atrações.

O calendário oficial das festas da cidade, distribuído pelo PIT - Posto de Informações ao Turista, mostra uma grande quantidade de festas no decorrer do ano:

\section{Calendário Cultural e Festivo de 2006}

JAN de 06 a 08 Encontro de Folia de Reis

FEV dias 03 e $04 \quad$ XXI Festival de Marchinhas de Carnaval de 23 a 28 Carnaval das Marchinhas

ABR dia 14 dia 15

Sexta-feira Santa (Procissão de Enterro)

dia 16

Sábado de Aleluia

Domingo de Páscoa

MAl dia 08

dia 27

Aniversário da Cidade

Encontro das Bandeiras (Festa do Divino)

JUN dia 04 dias 10 e 11

dia 15

Festa do Divino (Encerramento)

dias 16 e 17

dia 24

III Festival Gastronômico

Corpus Christi

X Festival de Música Junina (Arraia do Chi Pul Pul")

Encontro das Bandeiras (Festa de São Pedro)

JUL

VI Temporada de Inverno "Um Friuzinho Esquentadô"

dia 02 Festa de São Pedro (Encerramento)

de 20 a 23 XXXIV Romaria dos Cavaleiros (São Luis/Aparecida)

AGO de 04 a 06

Semana Dr. Oswaldo Cruz

de 18 a 20

Festa do Padroeiro "São Luis de Tolosa" 


\section{SET dias 02 e 03 Semana Elpídio dos Santos \\ Big Biker 2006}

\section{OUT dias 13 e 14 V Festival da Música Raiz Sertaneja "Mestre Dito Geraldo" \\ de 27 a 29 Festa do Saci}

NOV de 22 a 25 Festa de Santa Cecília

DEZ dia $25 \quad$ Natal

dia $31 \quad$ Reveillon

A nota de rodapé do folheto acrescenta: outras festas/atividades extracalendário, que por certo acontecerão, serão divulgadas pela mídia e pelo site: www.saoluizdoparaitingasp.gov.br.

Por depoimentos de entrevistados pode-se saber que há muitas festas nas roças que não constam desse calendário oficial, mas são bastante comemoradas embora ainda pouco atraiam turistas e moradores da zona urbana.

Como já exposto no capítulo 3, essas festas rurais raramente são objeto de pesquisas, no entanto, podem constituir um importante campo para colaboração no desenvolvimento de estudos sobre culturas de resistência.

Desta forma, o conjunto de questões que segue encaminha a apresentação dos resultados com vistas à identificação das manifestações festeiras da cidade.

A questão Você participa das festas? trouxe os seguintes resultados:

Tabela I

Você participa das festas?

\begin{tabular}{|l|c|}
\hline Não & $6 \%$ \\
\hline Sim & $94 \%$ \\
\hline Só freqüentando & $67,9 \%$ \\
\hline Preparando & $32,1 \%$ \\
\hline
\end{tabular}


É expressiva a participação das pessoas nas festas da cidade, denotando a importância que elas têm no cotidiano do lugar. Esse dado é também confirmado pelos depoimentos espontâneos, dos quais foram extraídas frases como:

"Festas tradicionais é a única coisa boa em Paraitinga."

"Quando não vai haver uma festa, há críticas porque a tiraram."

"Aqui é festa, acaba uma e já vem outra. Se acabarem as festas, acaba a cidade. Já nos acostumamos a viver das festas. Mas já acabou muita coisa e não devia."

Esses depoimentos confirmam o conceito de que entre as manifestações populares as festas destacam-se no gosto do povo brasileiro. $E$ ainda, como está citado no capítulo 2 e de acordo com Nazareth Ferreira, fazer festa significa procurar-se a si mesmo e à sua identidade; é buscar reencontrar as origens histórico-culturais, no ato comunicativo e comunitário. As festas possibilitam uma construção sólida da identidade cultural, dotando a comunidade de conscientização e de sentimento de pertencimento.

As festas populares têm a capacidade de gerar rendas em pequenas localidades, distantes dos fluxos financeiros da economia globalizada. A frase de Milton Santos, "gente junta cria festa e festa gera economia", encontra o seu correspondente no depoimento de uma entrevistada:

"Já que não tem emprego, vamos de festas. Vamos festejar. As nossas festas beneficiam a gente. São portas que abrem, restaurantes, barraquinha, a gente pode vender as coisas que a gente faz."

A metade das pessoas que se envolvem com o preparo das festas, aponta que se dedicam ao preparo de alimentos, seja doando, seja vendendo.

Em resposta à questão De quais festas da cidade você participa? obteve-se que $95,1 \%$ do universo dos pesquisados participam de pelo menos uma festa da cidade. Foi dada a liberdade de escolher mais que uma festa e registrou-se 422 citações. As mais citadas foram:

Tabela II 


\begin{tabular}{|l|c|}
\hline De quais festas da cidade você participa? \\
\hline Evento & \% \\
\hline Festa do Divino & 91,1 \\
\hline Carnaval & 78,4 \\
\hline Festival de Marchinhas de & 58,4 \\
Carnaval & \\
\hline Corpus Christi & 54,4 \\
\hline Procissão da Sexta-Feira Santa & 53,1 \\
\hline Aniversário da Cidade & 50,6 \\
\hline Encontro da Folia de Reis & 49,3 \\
\hline Festival de Música Junina & 49,3 \\
\hline Festa do Padroeiro & 49,3 \\
\hline
\end{tabular}

Nesta questão havia a possibilidade de mais de uma escolha.

Da seleção de festas que compuseram as opções dessa questão apenas a Festa de Santa Cecília não foi incluída porque não foi citada na pesquisa preliminar nenhuma vez. Trata-se de uma festa recém acrescentada ao calendário e que ainda não tem muitos adeptos e nenhum dos pesquisados lembrou-se dela.

Esta questão recebeu dos mais jovens, faixa etária de 15 a 25 anos, a primeira discrepância a que se referiu a análise inicial das respostas à pesquisa. Os mais jovens elegeram o Carnaval como a festa da qual mais participam, seguida pela Festa do Divino.

Os resultados de $91,1 \%$ para a Festa do Divino e $78,4 \%$ para o Carnaval confirmam os estudos elaborados pelos autores indicados no capítulo 3 como as comemorações mais conhecidas da cidade. A Festa do Divino, como já foi muito estudada por pesquisadores sociólogos, carrega em seu significado muitas riquezas culturais, elementos importantes para a preservação da tradição. O Carnaval é concebido essencialmente pela cultura do povo luizense, por meio dos seus elementos míticos e lendários que povoam o imaginário das pessoas, ilustrados pelos bonecos gigantes que resgatam as figuras de poetas, músicos e de personalidades do seu cotidiano.

A própria música, as marchinhas carnavalescas, únicas cantadas e tocadas durante essa festa, são de autoria dos compositores da cidade, valorizando os músicos locais. Essa valorização da musicalidade e criatividade 
local está manifesta quando os pesquisados escolhem o Festival de Marchinhas Carnavalescas como a terceira festa mais importante da cidade e a que precede a celebração do Carnaval. Isto confirma Milton Santos, para quem as festas representam também o momento de manifestação artística e estética, construindo espacialidades, nas quais as pessoas expressam a sua capacidade inventiva, criativa e espontânea, reveladoras de aspectos significativos da identidade cultural do grupo social.

Tanto a Festa do Divino quanto o Carnaval preservam a tradição original e originária da cidade. Enquanto a primeira reúne na sua celebração participantes, na sua maioria da própria cidade, o Carnaval vem atraindo número cada vez maior de turistas. O Comtur registrou neste ano de 2006, aproximadamente 20.000 turistas nessa festa.

Observa-se que ambas as manifestações preservam o caráter da identidade cultural, que para Ortiz assegura a perenidade de uma memória popular, diferenciando-a da identidade nacional, que se configura como um produto da história social e não da ritualização da tradição, estendendo-se à sociedade como um todo, impondo-se a todos os grupos, como é o conceito do Carnaval brasileiro, construído e espetacularizado pela grande mídia. A mídia hegemônica tem provocado a perda do referencial das sociedades e a ameaça da perda de seus símbolos culturais e dos traços ainda vivos que comprovam o seu passado.

Em São Luis do Paraitinga, essas festas estão próximas do mito e se manifestam ritualmente encarnadas no grupo que as celebram, portanto preservadoras da memória cultural e mantidas pela comunidade.

Para uma análise qualitativa da participação nas festas e o que elas significam para os moradores de São Luis do Paraitinga, formulou-se as seguintes questões:

É importante preservar as festas tradicionais da cidade? A esta pergunta foram obtidas $98,6 \%$ de respostas afirmativas. 
Quando questionados por quê?, obteve-se:

Tabela III

\begin{tabular}{|l|c|}
\hline \multicolumn{2}{|l|}{ Por quê? } \\
\hline Opções & $\%$ \\
\hline $\begin{array}{l}\text { Continuidade das nossas tradições e } \\
\text { da história da cidade }\end{array}$ & 80,5 \\
\hline $\begin{array}{l}\text { O povo precisa das festas para se } \\
\text { encontrar }\end{array}$ & 30,5 \\
\hline $\begin{array}{l}\text { Atrai gente de fora, melhora o } \\
\text { comércio }\end{array}$ & 47,2 \\
\hline
\end{tabular}

Nesta questão havia a possibilidade de mais de uma escolha.

Foram ainda citadas outras razões, como:

pela cultura, para manter a identidade do povo, pela religião, para os mais velhos passarem tradições aos mais jovens, por razões relacionadas ao turismo e à melhoria do comércio da cidade.

O percentual de respostas para Continuidade das nossas tradições e da história da cidade, sinaliza a preocupação da comunidade luizense na preservação de seus valores e na organização do seu passado, do seu presente e do seu futuro. Marca também que as festas são o espaço de convivência social e atrativo para a captação do turismo para a cidade, ainda muito pouco explorada pelos órgãos responsáveis pelo turismo. Depoimentos dos pesquisados apontam a necessidade de ações mais efetivas para que haja um crescimento econômico por meio do turismo. Quais sejam:

"Deveria ter mais festas. Ter feiras de artesanato nos finais de semana."

"Na época das festas falta policiamento, especialmente no Carnaval e também falta infra-estrutura, especialmente banheiros."

"Precisava resgatar a essência da cidade pela educação. Recuperar danças, catira e jongo, por exemplo. Na Secretaria Municipal de Cultura falta apoio para resgatar músicas de raiz. Festa do Saci é resgate da cultura popular. As festas trazem mais movimento, é bom para o comércio, mas também traz drogas e violência."

"As festas têm que se voltar para o turismo, mudar a cabeça do povo e dar mais valor para o turista". 
A questão Qual a principal razão pela qual as pessoas da cidade participam das festas? foi uma questão aberta, à qual $82 \%$ dos pesquisados responderam. As razões citadas foram:

Tabela IV

Qual a principal razão pela qual as pessoas da cidade participam das festas?

\begin{tabular}{|l|c|}
\hline Resposta & $\%$ \\
\hline Por diversão & 32,3 \\
\hline Por religiosidade/fé & 26,4 \\
\hline $\begin{array}{l}\text { Porque o pessoal da cidade é } \\
\text { festeiro }\end{array}$ & 23,5 \\
\hline Por tradição & 23,5 \\
\hline
\end{tabular}

Nesta questão havia a possibilidade de mais de uma escolha.

Estas respostas tendem a confirmar as festas como espaço de convivência social e de identidade cultural. Conforme Sodero, tão bem lembra no capítulo 3 , as festas

“... servem como instrumento de interação social, de compreensão de si mesmo, da manifestação da diversidade, de afirmação da identidade, englobando e permitindo a todos que se reconheçam como parte de um único povo, de um só passado, de uma história comum. Elas abrem espaço importante para que os indivíduos tenham oportunidade de participar do conjunto da sociedade..."

\subsection{Os processos comunicacionais hegemônicos e suas relações com a cultura local}

O conjunto de questões relacionadas neste ítem tiveram por objetivo compreender a relação entre midia hegemônica com as manifestações culturais locais, tanto na dimensão da dialética entre o local e o global quanto no possível domínio do hegemônico sobre o local. 
O formulário procurou abordar os meios de comunicação habituais da cidade, usados para divulgação das suas manifestações culturais, com ênfase na comunicação radiofônica.

A questão $O$ que mais ajuda para que as festas aconteçam todos os anos?, trouxe as seguintes respostas:

Tabela $\mathrm{V}$

O que mais ajuda para que as festas aconteçam todos os anos?

\begin{tabular}{|l|c|}
\hline Meio de divulgação & $\%$ \\
\hline Rádio & 46,5 \\
\hline Ação da Prefeitura & 39,7 \\
\hline Ação da Igreja & 27,4 \\
\hline Cartazes e folhetos & 24,6 \\
\hline TV & 12,3 \\
\hline
\end{tabular}

Nesta questão havia a possibilidade de mais de uma escolha.

As respostas mais freqüentes, obtidas com a questão: Como fica sabendo dessas festas e suas atividades? trouxe os seguintes resultados:

Tabela VI

Como fica sabendo dessas festas e suas atividades?

\begin{tabular}{|l|c|}
\hline Meios & $\%$ \\
\hline Por cartazes & 46,3 \\
\hline Pelo rádio & 46,3 \\
\hline
\end{tabular}

Tabela VII

\begin{tabular}{|l|c|}
\hline Qual a emissora? & $55,2 \%$ \\
\hline Paraitinga & $7,8 \%$ \\
\hline Band Vale & $2,6 \%$ \\
\hline Metropolitana & $2,6 \%$ \\
\hline 94 FM & $2,6 \%$ \\
\hline Taubaté &
\end{tabular}

Tabela VIII

Outras formas de conhecimento sobre as festas 


\begin{tabular}{|l|c|}
\hline Por amigos & $39 \%$ \\
\hline Por folhetos & $39 \%$ \\
\hline Pela TV & $6 \%$ \\
\hline
\end{tabular}

Estes resultados apontam para uma atuação significativa do veículo rádio na divulgação das manifestações culturais da cidade, mesmo dividindo essa indicação com o meio cartaz que se configura um esforço de comunicação bastante utilizado e com resultados eficazes. A larga vantagem que a Rádio Paraitinga obteve sobre as demais emissoras regionais demonstra que ela desempenha papel importante na divulgação das festas tradicionais.

Este dado é significativo para o entendimento de que o imaginário do povo luizense, em relação às suas tradições culturais, pode estar preservado da ameaça da mídia hegemônica, cuja linguagem e significados são impostos à vida das pessoas de todos os lugares, dando contornos hegemônicos ao seu pensamento e à memória não mais enraizada em tradições regionais e locais, como entende Denis de Moraes, visto no capítulo 1.

Por outro lado, é preciso registrar-se que essa audiência da Paraitinga deve-se também ao fato de que as demais emissoras da região não têm boa sintonia em várias partes da cidade. Uma mudança na instalação de suas antenas pode alterar essa situação de conforto para a rádio da cidade, o que poderá ameaçá-la de concorrência na audiência dos ouvintes.

Outras formas de conhecimento e divulgação das festas indicam que a comunicação interpessoal, isto é, por amigos, alcança um índice expressivo, o que demonstra um processo comunicacional sólido e mobilizador da vida da cidade. Esse fator está conjugado a outros meios citados espontaneamente, como o carro-falante da prefeitura, as conversas na escola, o calendário oficial, a internet, a igreja, o boca-a-boca, que estabelecem processos comunicacionais formados pela participação da comunidade de forma espontânea e intensa, compartilhando suas experiências no fluxo da vida cotidiana. 
Frases citadas pelos pesquisados reforçam o processo desse fluxo do cotidiano:

"O povo ajuda muito para as festas".

"Eles divulgam (a rádio) pelo nome das ruas, ninguém sabe onde é. Tem que falar que é a rua onde mora o fulano, da padaria do fulano..."

"É fácil saber quando tem festa. Festa é o que mais tem na cidade".

"Fico sabendo das festas pelas pessoas e pelo calendário já tradicional. Todo mundo sabe quando vai acontecer..."

"O pessoal de fora curte muito as festas, é muito participativo. Todos precisam ajudar para continuidade das festas. Cada um faz uma parte e acaba por fazer uma divulgação completa”.

As respostas às questões abaixo relacionadas neste item demonstram que além dos processos comunicacionais espontâneos, vistos anteriormente, a presença do meio radiofônico também mantem diversos graus de sintonia com a cidade.

As respostas obtidas com a pergunta Que rádios você escuta aqui na cidade? indicam

Tabela IX

Que rádio você escuta aqui na cidade?

\begin{tabular}{|l|c|}
\hline Rádio & $\%$ \\
\hline Paraitinga & 86,5 \\
\hline Band Vale & 35,3 \\
\hline Metropolitana & 17,0 \\
\hline Jovem Pan & 9,7 \\
\hline Difusora & 3,6 \\
\hline
\end{tabular}

Nesta questão havia a possibilidade de mais de uma escolha.

E ainda, quando perguntados Qual a que você mais ouve/prefere?, os resultados foram:

Tabela X Qual a que você mais ouve/prefere?

\begin{tabular}{|l|c|}
\hline Emissora & $\%$ \\
\hline Paraitinga & 55,8 \\
\hline Band Vale & 23,0 \\
\hline
\end{tabular}




\begin{tabular}{|l|c|}
\hline $\begin{array}{l}\text { Difusora, Gospel FM, Rede } \\
\text { Viva, Metropolitana, Nossa } \\
\text { Rádio, Jovem Pan }\end{array}$ & 21,2 \\
Não citaram preferência & 26,5 \\
\hline
\end{tabular}

Os pesquisados poderiam escolher mais que uma emissora.

Considerando o alto índice de respostas concentrado nas emissoras Band Vale e Paraitinga nessas questões, pode-se inferir que essas são as rádios que detém maior faixa de ouvintes da cidade. Considerando ainda que a Paraitinga aparece citada mais que o dobro de vezes em relação à Band Vale, em ambas as perguntas, pode-se compreender que a Paraitinga detém a supremacia de audiência sobre a Band Vale.

A análise qualitativa resultante das respostas livres dos pesquisados, trouxe dados a respeito dos motivos dessa preferência, a saber:

Por que prefere a Paraitinga: porque pega melhor; é daqui e fala da cidade; ela é interessante e as outras não.

Por que prefere a Band Vale: porque tem boa música; pega bem; já estou acostumado; sinal mais forte; informações da estrada; menos comercial; mais música e mais notícia.

A questão Quantos aparelhos de rádio você tem em casa? pretendeu conhecer qual o significado do veículo de comunicação rádio para os pesquisados no seu cotidiano, inclusive pela presença física do objeto. Os resultados obtidos com as respostas foram:

Tabela XI

Quantos aparelhos de rádio você tem em sua casa?

\begin{tabular}{|c|c|}
\hline Quantidade & $\%$ \\
\hline 00 & 2,5 \\
\hline 01 & 50,6 \\
\hline 02 & 29,1 \\
\hline 03 & 13,9 \\
\hline 04 & 2,6 \\
\hline 05 & 1,3 \\
\hline
\end{tabular}


Entende-se que esses dados denunciam a importância do veículo para essa população pesquisada. Numa época em que a hegemonia televisiva nos meios de comunicação de massa, em especial para o entretenimento, é inegável, esses resultados demonstram o importante papel que o veículo rádio desempenha na vida das pessoas. A preferência dos pesquisados pelos programas da emissora da cidade, que serão apresentados mais adiante, apontarão que o rádio pode realmente ser considerado o companheiro dos ouvintes, com o qual as pessoas podem executar suas tarefas diárias, onde quer que aconteçam e quaisquer que elas sejam, sem que precisem dispensar a ele atenção exclusiva.

Não foi incluída no formulário qualquer questão que levantasse a audiência ou preferência pela televisão ou outro meio de comunicação, em detrimento do rádio. Por outro lado, também não houve qualquer citação espontânea, embora apenas esse fato não seja suficiente para que se possa afirmar a supremacia do rádio sobre qualquer outro veículo de comunicação de massa.

\subsection{A Rádio Paraitinga e as manifestações culturais da cidade}

Para analisar os processos radiofônicos da cidade visando compreender as possíveis relações estabelecidas com as manifestações culturais da cidade foi colhida a programação da Rádio Paraitinga, elaboradas perguntas que buscassem descobrir a atuação da Rádio e seu modo de comunicação, entender as percepções dos ouvintes em relação à Rádio, buscar informações sobre a participação do ouvinte na programação e nos serviços de utilidade pública.

\subsubsection{A programação da Rádio Paraitinga}

Foram relacionados 19 programas levados ao ar de segunda a sextafeira e, como já mencionado, são acentuadamente marcados pelo gênero musical. Dentro da programação, nesse gênero, encontra-se: 


\section{Música sertaneja:}

Raiz Sertaneja, das $5 \mathrm{~h}$ às $7 \mathrm{~h}$ e

Sertanejo Regional, das $7 \mathrm{~h}$ às $9 \mathrm{~h}$.

Músicas pop variadas nacionais:

Freqüência Máxima, das $9 \mathrm{~h}$ às $11 \mathrm{~h}$, atende pedidos de ouvintes, programa ao vivo de música variada apresentado pelo locutor Leandro Birão;

Noite de Sucessos, das $20 \mathrm{~h}$ às $22 \mathrm{~h}$, programa ao vivo apresentado pelo locutor Leandro Birão;

Música pop variada (são cinco programas gravados) das $11 \mathrm{~h}$ às $11 \mathrm{~h} 30$, das $12 \mathrm{~h}$ às $13 \mathrm{~h}$, das $19 \mathrm{~h}$ às $20 \mathrm{~h}$, das $22 \mathrm{~h}$ às $22 \mathrm{~h} 30$ e das $23 \mathrm{~h}$ às $23 \mathrm{~h} 30$;

Seleção Brasileira, das 16h às 17h, apresentado por Daniel Tucci, com MPB, pop e rock nacional.

Músicas pop variadas nacionais e internacionais:

Paraitinga Music, das $13 \mathrm{~h}$ às $16 \mathrm{~h}$, programa ao vivo, com dance music, pop internacional na sua maioria, mas também atende pedidos de ouvintes com música nacional, voltado para o público jovem, apresentado pela locutora Angélica.

Let's Rock!, das $17 \mathrm{~h}$ às $18 \mathrm{~h}$ e Lets Rock! Na Madrugada, das Oh à $1 \mathrm{~h}$, apresentam rock nacional e internacional, seu locutor é Daniel Tucci;

Meia Hora Dance, das $22 \mathrm{~h} 30$ às $23 \mathrm{~h}$, programa gravado apresenta música eletrônica;

Meia Hora Black, das $23 \mathrm{~h} 30$ à Oh, programa gravado, apresenta black music, hip hop, reggae e soul;

\section{Músicas locais:}

Paraitinga Hits, das18h30 às 19h, programa gravado com músicas de compositores da cidade.

Músicas de todos os estilos:

Noite afora, de $1 \mathrm{~h}$ a $5 \mathrm{~h}$, programa gravado.

Ainda fazem parte da programação diária da semana: 
Jornal Paraitinga, das $11 \mathrm{~h} 30$ às $12 \mathrm{~h}$, onde o locutor Daniel Tucci fala das notícias de esportes, cultura, política e variedades, selecionadas do jornal que empresta da Biblioteca da cidade, pois a emissora não assina jornais, nem tem internet.

Santo Terço, das $18 \mathrm{~h}$ às $18 \mathrm{~h} 30$.

Há programas especiais que são levados ao ar uma vez por semana, a saber:

Anarquia Cultural, às quintas-feiras, das $22 \mathrm{~h}$ à $0 \mathrm{~h}$, tem produção $\mathrm{e}$ apresentação de Patrícia Magalhães, Paulo Baroni, Assis Keike e Daniel Tucci. Trata-se de um programa de entrevistas, agenda cultural, poesias, música ao vivo com compositores da cidade, matérias sobre esportes e humor.

Voz da Paróquia, às sextas-feiras, das $12 \mathrm{~h}$ às $13 \mathrm{~h}$, com o locutor Benedito Domingos que é Ministro da Eucaristia atuando na Igreja Matriz e apresenta nesse programa as notícias da paróquia, seus eventos, suas atividades e suas festas.

Luz Espírita, às sextas-feiras, das $21 \mathrm{~h}$ às $22 \mathrm{~h}$. Não tem freqüência, nem apresentador regular. Atualmente não tem sido levado ao ar.

Programa Assembléia de Deus, às segundas e quintas-feiras, das $21 \mathrm{~h}$ às $22 \mathrm{~h}$. Não tem freqüência, nem apresentador regular. Atualmente não tem sido levado ao ar.

Paraitinga da Saudade, aos sábados, das $10 \mathrm{~h}$ às $12 \mathrm{~h}$, produzido e apresentado pelos irmãos Domingos, com músicas dos anos 40, 50, boleros, bandas musicais, orquestras, além de crônicas da cidade compostas pelo Benedito Domingos. Hoje esse programa não tem sido levado ao ar porque seus produtores estão reformulando seu repertório.

Estrada do Sertão, aos domingos, das $7 \mathrm{~h} 30$ às 9h30, Nelsinho do Mato Dentro apresenta música sertaneja e raiz. 
Viva a Vida, aos domingos, das $9 \mathrm{~h} 30$ às 12h, apresentado por Fia, da Pastoral da Criança e Pastoral da Fé e Política. Trata-se de um programa de entrevistas, ao vivo, com pessoas dos diversos segmentos da cidade, apresentando debates, músicas religiosas e variadas e que também atende pedidos de ouvintes.

Todos os Ritmos, aos domingos, das $12 \mathrm{~h}$ às $15 \mathrm{~h}$, no qual o locutor Leandro Verônico atende aos pedidos musicais dos ouvintes.

\subsubsection{A Rádio Paraitinga e seus ouvintes}

A questão Que rádios você escuta aqui na cidade? teve a Rádio Paraitinga como a mais citada.

Tabela XII

\begin{tabular}{|l|c|}
\hline \multicolumn{2}{|l|}{ Que rádios você escuta aqui na cidade? } \\
\hline Emissoras & $\%$ \\
\hline Paraitinga & 86,5 \\
\hline Band Vale & 35,3 \\
\hline Metropolitana & 17,0 \\
\hline Jovem Pan & 9,7 \\
\hline Viva FM & 7,3 \\
\hline Difusora & 3,6 \\
\hline
\end{tabular}

As respostas obtidas para a pergunta Você ouve a Rádio Paraitinga? teve $88,9 \%$ de respostas $\operatorname{Sim}$.

Para a afirmação "O que eu mais gosto na Rádio Paraitinga é que ela é da cidade e fala dos assuntos da cidade." o pesquisado deveria optar pelas respostas abaixo. Os resultados foram:

Tabela XII

"O que eu mais gosto na Rádio Paraitinga é que ela é da cidade e fala dos assuntos da cidade".

\begin{tabular}{|l|c|}
\hline Resposta & \% \\
\hline Concordo totalmente & 83,1 \\
\hline Concordo em parte & 14,0 \\
\hline Discordo em parte & 2,9 \\
\hline
\end{tabular}


Uma avaliação qualitativa das respostas ao questionamento por que concordava totalmente, trouxe alguns indícios que podem ser reveladores do quanto a emissora participa das manifestações culturais da cidade e também o quão afetuosamente alguns dos pesquisados se referiram a ela. Foram registradas frases tais como:

"A programação é voltada para a cidade, a rádio fala de tudo da cidade."

"É a única que fala dos assuntos da cidade, é muito bom para nós pois a gente sabe das coisas da nossa cidade, o povo fica informado, é bom ouvir coisas daqui."

"Fala bem da nossa cidade, é importante para a cidade, porque é a nossa radinha!"

Observa-se que os $16,9 \%$ que discordaram/concordaram em parte, colocaram motivos como:

"Deveria falar de outras cidades".

"Fala pouco da cidade, não gosto tanto, não fala dos assuntos da cidade."

"Deveria dar mais atenção ao pessoal do Alto do Cruuzeiro (bairro onde está instalada a emissora)."

"Fala da política, mas do lado dos políticos."

"Fala das coisas que nem sempre interessam para a cidade."

"As vezes tem muita propaganda, é mais preocupada com lucro."

Essas falas indicam a visão crítica do ouvinte sobre a atuação da emissora, denotando as expectativas dos pesquisados.

Todos os pesquisados responderam à questão Quais os programas da Rádio Paraitinga que você prefere? e podiam escolher mais que um programa. Os resultados mostram que os preferidos da programação levada ao ar, de segunda à sexta-feira, são:

Tabela XIII

Quais os programas da Rádio Paraitinga que você prefere?

\begin{tabular}{|l|l|l}
\hline Programa & Horário & $\%$
\end{tabular}




\begin{tabular}{|c|c|c|}
\hline \multicolumn{3}{|c|}{ Programação Regular } \\
\hline Sertanejo Regional & das 7,00 às 9,00 & 28,9 \\
\hline Música Variada & das 9,00 às 11,30 & 27,7 \\
\hline Jornal Paraitinga & das 11,30 às 12,00 & 18,0 \\
\hline Raiz Sertaneja & das 5,00 às 7,00 & 18,0 \\
\hline Paraitinga Music & das 13,00 às 16,00 & 16,8 \\
\hline Santo Terço & das 18,00 às 18,30 & 12,0 \\
\hline Seleção Brasileira & das 16,00 às 17,00 & 8,4 \\
\hline Let's Rock & das 17,00 às 18,00 & 7,2 \\
\hline Paraitinga Hits & das 18,30 às 19,00 & 7,2 \\
\hline $\begin{array}{l}\text { Música Pop } \\
\text { Variada }\end{array}$ & das 19,00 às 20,00 & 6,0 \\
\hline Noite de Sucessos & das 20,00 às 22,00 & 6,0 \\
\hline Músicas Variadas & das 22,00 às 22,30 & 1,2 \\
\hline $\begin{array}{l}\text { Let`s Rock na } \\
\text { Madrugada }\end{array}$ & das 0,00 às 1,00 & 1,2 \\
\hline Noite a fora & de 1,00 às 5,00 & 1,2 \\
\hline Meia Hora Dance & das 22,00 às 23,00 & ---- \\
\hline Meia Hora Black & das 23,30 à & ---- \\
\hline \multicolumn{3}{|c|}{ Programas Especiais } \\
\hline Estrada do Sertão & das 7,30 às 9,30 - Dom. & 16,8 \\
\hline $\begin{array}{l}\text { Paraitinga da } \\
\text { Saudade }\end{array}$ & sábados - pela manhã & 9,6 \\
\hline Todos os Ritmos & das 12,00 às 15,00 - Dom & 9,6 \\
\hline Anarquia Cultural & das 22,00 à $0,00-5^{a} s$ & 6,0 \\
\hline \multicolumn{3}{|c|}{ Programas Religiosos } \\
\hline A Voz da Paróquia & das 12,00 às $13,00-6^{a} s$ & 18,0 \\
\hline Viva a Vida & das 9,00 às 12,00 - Dom. & 7,2 \\
\hline $\begin{array}{l}\text { Assembléia de } \\
\text { Deus }\end{array}$ & $\begin{array}{l}\text { das } 21,00 \text { às } 22,00- \\
2^{a} \text { s e } 5^{a} s\end{array}$ & 1,2 \\
\hline Luz Espírita & das 21,00 às $22,00-6^{a} s$ & ---- \\
\hline
\end{tabular}

Os programas matutinos, os que são levados ao ar das $5 \mathrm{~h}$ às $12 \mathrm{~h}$, são os mais ouvidos da rádio, e na seqüência, o que segue pela tarde, das $13 \mathrm{~h}$ às 16h. Estes dados indicam que a Rádio Paraitinga, durante o dia, cumpre o seu papel junto ao ouvinte que busca companhia para os seus afazeres. Dentre os pesquisados havia donas de casa, estudantes, lojistas, atendentes de balcão de açougue, bar, restaurante, além de aposentados.

É conhecido o fato de que as emissoras de rádio, comunitárias ou não, são realmente companheiros dos ouvintes durante o dia, sobrepondo-se à soberania da televisão, que à noite é a preferida da maior parte das pessoas. São Luis do Paraitinga mostra que ali não é diferente, o rádio acompanha os 
luizenses em suas tarefas durante o dia e, à noite, quando provavelmente seja possível sentar-se e concentrar-se, a televisão ocupa a sua atenção. Os programas de fim de tarde e os noturnos tiveram menos escolhas, podendo-se inferir que a partir do final da tarde, provavelmente a televisão já comece a ocupar o lugar do rádio.

Nas respostas acima tabuladas, novamente os pesquisados da faixa etária de 15 a 25 anos mostraram preferência acentuada para o programa das $13 \mathrm{~h}$ às 16h, Paraitinga Music, diferindo das demais faixas etárias, cujas preferências recaíram sobre os programas da manhã. Além do fato de que o programa em referência é voltado para os adolescentes, pode-se considerar que pela manhã muitos dos jovens devam estar na escola.

No entanto, é preciso salientar que houve citação de preferência ao programa Santo Terço, das $18 \mathrm{~h}$ às $18 \mathrm{~h} 30$. Este dado provavelmente possa revelar que a religiosidade católica esteja marcadamente presente como característica dessa população, pois $79,6 \%$ se declararam católicos quando nos dados de identificação foi perguntada a religião praticada. O fato é confirmado quando se verifica que o programa A Voz da Paróquia, também católico, aparece nas citações de preferência dos ouvintes. Os demais programas religiosos, Assembléia de Deus e Luz Espírita, não são regulares e no período da pesquisa não estavam no ar. O primeiro foi pouco lembrado e o segundo sequer foi citado pelos pesquisados.

Outro dado que provavelmente venha confirmar a predominância da religião católica desse povo, é que a pesquisa sobre as festas tradicionais de São Luis do Paraitinga mostra o predomínio das festas religiosas sobre as demais festas. Desta forma, pode-se supor que elas podem estar sendo sustentadas pelo sentido de religiosidade católica do povo, confirmando os estudos de Sodero citados no capítulo III, nos quais o autor discorre sobre as festas tradicionais dos municípios do Vale do Paraíba, apontando para a origem no desenvolvimento da religiosidade popular católica.

Para Sodero, conforme já foi visto, as festas tradicionais são marcadas pela presença do misticismo sertanejo, do culto mariano e pelo tempo de 
festas, para saudar, pedir proteção e revigorar a crença no "seu santo". Há de se considerar, portanto, que essa acentuada religiosidade esteja presente em outras manifestações do comportamento e das escolhas desse povo, inclusive refletindo sobre suas preferências quanto aos programas radiofônicos.

Essa consideração pode também ser sustentada pelas respostas à pergunta Qual a principal razão pela qual as pessoas da cidade participam das festas?, conforme foi visto na Tabela IV, na qual encontrou-se citações para a opção religiosidade/fé. Observa-se que esta era uma pergunta aberta e as respostas surgiram espontaneamente e, mais que uma razão poderia ser registrada.

Aos programas especiais da emissora, a preferência recai sobre o Estrada do Sertão, com 16,8\%. O programa é levado ao ar aos domingos pela manhã. Percebe-se que a programação das primeiras horas do dia são voltadas aos programas de música sertaneja e, pelos dados tabulados, são bastante ouvidos na cidade. Desta forma, também aos domingos, a Paraitinga procura atender a preferência musical de seus ouvintes.

Uma análise dos resultados até aqui apresentados quanto a preferência à programação da Rádio Paraitinga mostra que ela tem atendido a públicos diferentes, sobretudo no que diz respeito aos programas musicais, que prevalecem sobre os outros gêneros. A emissora atende do sertanejo ao pop, música internacional, passando pela música popular brasileira e pelos programas denominados 'especiais' e religiosos.

A Rádio Paraitinga permanece 24 horas no ar, embora na maioria das vezes a emissora esteja no ar com programas gravados. Ressentem-se os locutores da ausência da comunidade na emissora, raros são os ouvintes que visitam a Rádio Paraitinga, seja para pedir música, seja para solicitar o anúncio de algum serviço de utilidade pública. Quando a participação do ouvinte acontece, é por meio do telefone e, na maioria das vezes, para solicitar música. Embora pareça contraditório, isso é típico das emissoras comunitárias, como se conheceu pelas leituras feitas para construção do referencial teórico. Uma 
pergunta precisa ser aqui colocada: o que a Paraitinga tem feito para incentivar seus ouvintes a participar de sua programação?

Além desse depoimento dos locutores, a pesquisa mostra, através dos resultados obtidos com as respostas à pergunta Você já participou de algum programa da Rádio?, que $53 \%$ das pessoas que responderam a esta questão optaram pelo Não. Outros dados estão apresentados na tabela abaixo.

Tabela XIV

\begin{tabular}{|l|c|}
\hline Se sim - Opção & $\%$ \\
\hline $\begin{array}{l}\text { Pelo telefone, fora do ar, pedindo } \\
\text { músicas }\end{array}$ & 75,0 \\
\hline $\begin{array}{l}\text { Pessoalmente, apresentando-se } \\
\text { em programa, ao vivo }\end{array}$ & 12,5 \\
\hline
\end{tabular}

Foi perguntado aos locutores e ao Diretor da emissora porque, na opinião deles, os ouvintes não freqüentavam a emissora ou não participavam ao vivo dos programas, e as respostas obtidas, ditas de uma maneira ou de outra, foram que "numa cidade pequena onde todos se conhecem, de modo geral, as pessoas têm vergonha ou medo de se expor, porque serão facilmente identificadas pelos seus vizinhos e amigos".

Pode-se inferir que os ouvintes não se "apropriam" da emissora, não sentem que podem ou têm o direito de utilizar esse espaço radiofônico. A Rádio Paraitinga, por ser comunitária, deveria incentivar a participação dos ouvintes e abrir espaço para que fosse mais útil do que é atualmente. Esse é um estudo que certamente merece ser realizado.

Quando se trata de utilizar o espaço radiofônico da emissora da cidade, as respostas à pergunta Quais dos serviços prestados pela Rádio Paraitinga já foram úteis pra você?, reforçam a percepção citada acima.

Tabela XV

Quais dos serviços prestados pela Rádio Paraitinga já foram úteis pra você?

\begin{tabular}{|l|c|}
\hline Opção & $\%$ \\
\hline Não respondeu & 24,1 \\
\hline
\end{tabular}


Os que responderam apontam o uso desses serviços da seguinte forma:

Tabela XVI

Quais serviços prestados pela Rádio Paraitinga já foram úteis pra você?

\begin{tabular}{|l|c|}
\hline Opção & $\%$ \\
\hline Dicas de saúde & 47,6 \\
\hline Notas Sociais & 38,0 \\
\hline Ajuda & 19,0 \\
\hline Outros & 19,0 \\
\hline $\begin{array}{l}\text { Não usou nenhum } \\
\text { serviço }\end{array}$ & 9,6 \\
\hline
\end{tabular}

Os pesquisados poderiam escolher mais que uma alternativa.

As respostas à alternativa Ajuda dizem respeito a divulgar pessoas desaparecidas ou documentos/objetos achados e perdidos,

Outros (serviços) corresponde a oferta e solicitação de emprego, divulgação de projetos, notícia de óbito, entre outras.

Para a pergunta $O$ que você não gosta na Rádio Paraitinga?, obteve-se as seguintes respostas.

\section{Tabela XVII}

\begin{tabular}{|l|c|}
\hline O que você não gosta na Rádio Paraitinga? \\
\hline Opção & $\%$ \\
\hline Não respondeu & 30,1 \\
\hline Respondeu & 69,9 \\
\hline - Tudo certo com a rádio & 41,3 \\
\hline - Razões & 28,6 \\
diversas/desagrado & \\
\hline
\end{tabular}

$30,1 \%$ dos pesquisados não respondeu e mais da metade dos $69,9 \%$ dos pesquisados que responderam, disseram que nada os desagradava na emissora. Por outro lado, vale a pena registrar algumas razões de desagrado citadas pelos pesquisados. 
Com relação à programação - não toca música de raiz, não toca hip hop, não toca funk, toca sempre as mesmas músicas, repete muito as mesmas músicas, toca muita música sertaneja. Não gosto dos seus programas religiosos, de futebol, do jornal; tem muita propaganda, comerciais feito num jeito caipira, não fala das coisas das outras cidades. Deveria falar mais de utilidade pública, ter mais dicas de saúde, campanhas de saúde, e finalmente um comentário que sintetiza este último bloco de críticas - "acho que ela não é comunitária".

Com relação à linguagem utilizada na emissora - os locutores se atrapalham pra falar; os locutores falam errado; os locutores são lentos; os locutores falam de um jeito muito caipira.

Essa percepção sobre a linguagem está reforçada pelas respostas à questão Como os locutores falam nos programas, que tipo de palavras ou expressões eles usam e que mais têm a ver com seu jeito de falar ou com o jeito da cidade?

$65 \%$ das pessoas responderam a esta questão e trouxeram as seguintes informações.

Tabela XVIII

Como os locutores falam nos programas, que tipo de palavras ou expressões......

\begin{tabular}{|l|c|}
\hline Opção & $\mathbf{\%}$ \\
\hline Não respondeu & 35,0 \\
\hline Respondeu & 65,0 \\
\hline - sotaque caipira/sertanejo/daqui & 50,0 \\
\hline - errado/pouco preparados & 22,2 \\
\hline - nada especial & 7,0 \\
\hline
\end{tabular}

O fato de serem fornecidas essas respostas, pode significar não só a falta de formação ou preparo dos locutores para atuação, mas porque são da comunidade, voluntários que se identificam com o meio e com o ouvinte. Nas 
entrevistas, os locutores mostraram que há uma preocupação com falar o português corretamente, no entanto, admitem a falta de formação específica e julgam ser mais importante falar a língua do ouvinte para estar próximo dele.

Os ouvintes pesquisados comparam a linguagem dos locutores da Rádio Paraitinga com a dos locutores de outras emissoras, como a Band Vale, por exemplo. Pode-se inferir que o ouvinte da Paraitinga espera da emissora de sua cidade um padrão melhor, comparado à de uma globalizada.

De acordo com Esmeralda Villegas Uribe,

"As rádios populares estão dentro de um contexto de mercado cultural amplo, no qual existem outras ofertas para as rádio-escutas, entre as quais devem se posicionar. Os ouvintes de rádios populares de alto-falantes, são ouvintes de emissoras comerciais, estão acostumados com certos modelos de rádio comercial e os legitimam; comparam o que se faz na rádio popular, e muitas vezes esperam encontrar nos alto-falantes, as características da rádio massiva”. ${ }^{101}$

Supõe-se que o mesmo possa ser atribuído aos ouvintes das rádios comunitárias, comparando a emissora de sua cidade com as comerciais de grandes conglomerados. Quem sabe até desejando que sua pequena emissora se torne uma emissora como aquelas. Isso é compreensível, a busca por um melhor padrão na linguagem da emissora de sua preferência denota uma crítica saudável e não necessariamente que ela deva se globalizar, pois ela pode continuar falando das coisas da cidade.

Com relação à participação da emissora na divulgação das festas da cidade, foco da pergunta A Rádio Paraitinga apóia as festas da cidade?, temos:

Tabela XIX

\begin{tabular}{|l|c|}
\hline \multicolumn{2}{|c|}{ A Rádio Paraitinga apóia as festas da cidade? } \\
\hline Opção & $\%$ \\
\hline Não respondeu & 15,6 \\
\hline Respondeu. Sim & 84,4 \\
\hline - Divulgando com antecedência & 95,7 \\
\hline - Informando atividades da festa & 75,7 \\
\hline
\end{tabular}

${ }^{101}$ Alto-Falantes: formas autônomas de expressão e de desenvolvimento local, in Vozes Cidadãs, p.132. 
- Orientando mudanças na cidade

55,7

Os pesquisados poderiam escolher mais que uma alternativa.

Como pode ser visto na tabela acima, todos que responderam à pergunta, apontaram como a Rádio Paraitinga apóia as festas da cidade. O alto índice de citações para as três alternativas do tipo de apoio que a rádio dá as festas, mostra que sua presença é reconhecida pelos ouvintes.

Por outro lado, comentários espontâneos dos pesquisados, ouvintes e locutores, denotam que é esperado mais da atuação da rádio neste aspecto. Frases como:

"É interessante para a cidade ter uma rádio comunitária. Ajuda a manter as festas, mas poderia fazer mais", de um ouvinte que respondeu o formulário.

E ainda:

"O ideal seria uma atuação como a que fizemos no Carnaval deste ano. A Rádio desceu para a praça, levamos os equipamentos e fizemos transmissão ao vivo, quase 24 horas no ar, sobre tudo o que acontecia na praça. Tivemos o apoio da Prefeitura para a manutenção do equipamento e também uma ajuda de custo para quem trabalhou. Já na Festa do Divino, não aconteceu. E poderia, é uma festa tão importante quanto a outra", do locutor da emissora Daniel Tucci, reafirmada pelo diretor da Paraitinga.

Essas falas demonstram que a expectativa é de uma atuação mais marcante, pela qual a emissora pudesse estar mais presente às festas da cidade.

\subsubsection{A Rádio Paraitinga: no horizonte do possível}

É importante conhecer a história da Rádio Paraitinga, pois como outras rádios comunitárias, teve dificuldades para iniciar seu funcionamento, conforme depoimentos concedidos na entrevista de 29 de julho pelo diretor da emissora André Luis Bilard.

A emissora começou suas atividades em 1998 quando o vereador André Luis comprou o equipamento da Rádio Estância Imperial. "Essa rádio era de propriedade do Ademir, um sargento da Polícia Militar da cidade, com quem eu trabalhava. Além de vereador, eu atuava, e ainda atuo, como Investigador de 
Polícia. A emissora estava fechada por uma ação do prefeito da época, que coagiu os anunciantes a não renovarem os contratos dos seus anúncios na emissora. Sem apoio dos comerciais, portanto sem recursos, a rádio Estância Imperial precisou sair do ar. Na época, a rádio transmitia as sessões da Câmara dos Vereadores, sempre muito polêmicas porque havia muita pressão contra a ação do prefeito", comenta André Luis.

Para "burlar" outras ações coibitivas do prefeito, o novo diretor pôs o equipamento na mão do padre que acabara de chegar à cidade. Quando perguntado de quem era a rádio, o padre dizia que era de um homem de fora da cidade. Ninguém sabia quem era o dono da rádio, dizia-se que era de um homem de São Paulo. "Na época, muito da programação era religiosa, pois era preciso justificar a direção que a emissora aparentemente tinha."

Enquanto isso, foi iniciado o processo para regularizar o funcionamento da rádio e ela ganhava audiência e credibilidade. Na mesma época também havia na cidade a Rádio Alvorada que só tocava música sertaneja. "Ela transmitia com uma potência muito alta, era ouvida até perto de Taubaté, o que era ilegal. $O$ equipamento muito potente estava interferindo inclusive em transmissão de TV e isso a fazia alvo de denúncias", lembra André.

A atuação dos locutores era acertada com André Luis. "Eu conversava com eles, acertava os detalhes, mas quem 'tocava' a rádio era o padre".

Quando saiu a liminar, André Luis assumiu a gestão da rádio. A Rádio Alvorada, que era a favor do prefeito, estava ilegal e acabou sendo fechada, alvo de denúncias. "Essas denúncias eram anônimas e traziam o pessoal da ANATEL à Rádio Paraitinga, mas quando viam que ela tinha autorização para funcionar, a Anatel procurava por outras que não estivessem operando legalmente. Foi assim que a Alvorada acabou sendo fechada e a Paraitinga pode continuar no ar." conta o diretor André Luis.

A Rádio já se chamava Paraitinga desde o início, quando estava sob a direção do padre e já teve três endereços, sempre na mesma rua, a Dr. Luiz de Aguiar, no Alto do Cruzeiro e opera na freqüência de 105,9 MHz. "No início, 
ficava no começo da rua, depois mudou para uma casa, lá pelo meio da subida do morro, onde fica a curva e agora aqui, no $n^{\circ} 500^{\prime \prime}$, comenta a locutora Fia, em entrevista à pesquisadora, no dia 26 de agosto. A casa era alugada até meados de julho, quando o diretor a comprou. De acordo com ele, isso diminuiria um pouco as despesas. No entanto, a casa entrou em reforma, pois o diretor vai se casar e resolveu morar lá.

Por telefone, em 7 de outubro, a locutora Angélica, disse que a obra tomou proporções maiores e a rádio precisou mudar-se. "Está numa rua perto da Igreja Matriz, num pequeno quarto da casa do Fernando, irmão do André Luis". A foto que se segue mostra a casa, já sem a placa da emissora e com o início das obras.

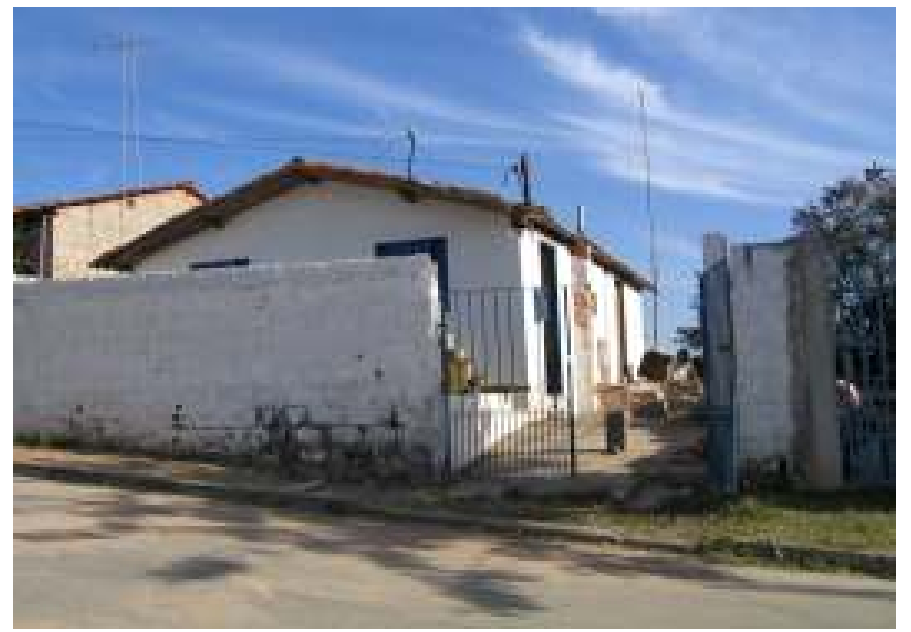

Foto da casa onde estava instalada a Rádio Paraitinga. Foto de Rosana Beneton, de 12/08/06.

Como vimos no capítulo 1, com Cicília Peruzzo, a rádio comunitária é uma emissora cuja organização se dá por uma associação sem fins lucrativos e a Paraitinga funciona legalmente graças à autorização de Uso de Radiofreqüência outorgada pela Agência Nacional de Telecomunicações ANATEL, à Associação Cultural para Difusão das Tradições e Hábitos Luizenses, pelo ato $\mathrm{n}^{\circ}$. 48.364, de 9 de dezembro de 2004, cuja cópia do documento é o anexo VI. 


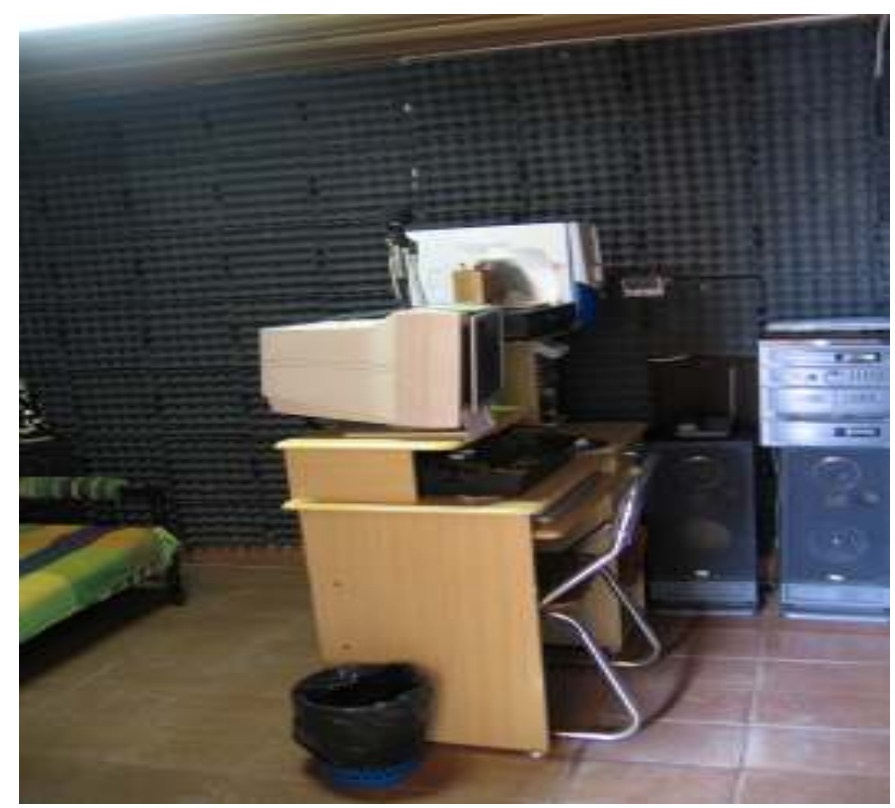

Estúdio A da Rádio Paraitinga. Foto de Rosana Beneton.

André Luis confessa que essa associação tem como presidente o Luiz Fernando, seu irmão. Uma vez que exerce cargo político, não poderia presidir a associação ou dirigir a emissora, pois a rádio comunitária deve ter autonomia em relação ao poder público.

A programação foi se delineando, ao longo do tempo, com a entrada dos locutores. "Os primeiros a entrar, o Alcides e o Leonildo, eram da Rádio Estância Imperial. Depois veio o Daniel. Ele tinha chegado na cidade e a mãe dele era amiga da minha irmã que me disse que ele tinha interesse em trabalhar na rádio, pois já tinha uma experiência de São Paulo. Como a preferência do Daniel era o rock e eu também gostava de rock, disse pra ele fazer um teste. Gostei do programa que ele apresentou e, desde então, o Daniel produz e apresenta o Let's Rock e o Let's Rock na madrugada." diz André. Depois, o locutor Daniel se ofereceu para apresentar um programa de notícias, pois a emissora não tinha radiojornal e ele julgava importante ter um. Outro programa que esse locutor apresenta é o Anarquia Cultural, às quintasfeiras, no qual ele sempre traz outras pessoas para apresentar o programa com ele. 
O Birão também está na rádio desde o início. Como outros, apresentava na Alvorada e quis vir para a Paraitinga. Os irmãos Domingos já faziam o programa Paraitinga da Saudade, na Rádio Alvorada e, porque o início da Paraitinga foi estreitamente ligado a Igreja, o Benedito Domingos começou a apresentar o Voz da Paróquia, às sextas-feiras, das $12 \mathrm{~h}$ às $13 \mathrm{~h}$.

"O Alcides tem dificuldades na fala, é gago, então fica na técnica, porque na locução as pessoas caçoavam muito dele. Mesmo assim ele gostava muito de fazer locução." relembra o diretor da emissora.

A locutora Fia que apresenta o Viva a Vida também é do início da emissora e o programa que faz é ligado ao seu trabalho na Pastoral da Criança e na Pastoral Fé e Política. O programa sempre trouxe debates, entrevistas e atende aos pedidos de músicas dos ouvintes. É importante para a comunidade, pois ela abre espaço para que as pessoas se coloquem e critiquem. "Mas, às vezes, ela exagera nas críticas que faz. Outras vezes, ela faz críticas e não dá direito de resposta, isso eu já falei pra ela. Por essa razão, às vezes ela é muito criticada e, de vez em quando, temos problemas", confessa André Luis.

A locutora Angélica tem 17 anos e veio no começo de 2005, pelo Projeto Gente Jovem, do Governo do Estado. Esse projeto identifica na comunidade os adolescentes que vivem em situação de risco, oferece a eles cursos que possam dirigi-los ao primeiro emprego e os ajuda a se colocarem. Começou como recepcionista, atendendo ao telefone e, aos poucos, foi aprendendo a operar a técnica. Mostrou-se interessada em fazer um programa e lhe foi dada a oportunidade de apresentar o programa da tarde, voltada ao público jovem, o Paraitinga Music. "Deu certo, ela acertou com o pessoal que ouve a emissora à tarde, os adolescentes", lembra o diretor.

A emissora veicula anúncios comerciais, na condição de apoio cultural. De acordo com o André Luis, essa receita cobre, quase sempre, uns $90 \%$ das despesas mensais. O que falta é assumido por ele. Alguns locutores recebem uma ajuda de custo da emissora. Comenta: "A manutenção da rádio é 
praticamente custeada por mim, gosto de rádio e, embora não tenha formação de radialista, nem apresente nenhum programa, gosto de rádio".

"Procuro não interferir na programação, converso muito com os locutores, advirto para alguns cuidados quando estão ao microfone, especialmente quanto a falar corretamente o português e não tocar música funk, que em geral tem umas letras que as famílias da cidade não aceitam. Afinal a rádio está aí para todos ouvirem e alguns se sentem ofendidos com certas músicas atuais". confessa André.

Em algumas festas, quando a emissora participa, recebe algum recurso financeiro, por exemplo, do Comtur - o Conselho Municipal de Turismo, no Carnaval, para custear o equipamento, que sempre acaba precisando de mais cabos ou manutenção. O COMTUR também deu uma ajuda para os locutores que, em vez de aproveitá-la, trabalharam muitas horas nessa festa.

A gestão é do diretor, em vez de coletiva, e por isso é criticado. Alguns depoimentos dos pesquisados referem-se à necessidade de ser mais transparente nessa gestão, "porque se é rádio comunitária, é do povo, não é para dar lucro. Nunca se sabe se ali dá lucro ou não", como foi colocado por um pesquisado. 


\section{CONSIDERAÇÕES FINAIS}

\section{Considerações Finais}

“... a informação local tem espaço privilegiado, ela personaliza seu ouvinte e estimula o sentimento de solidariedade e de participação nos principais acontecimentos da vida da comunidade."

Arthur da Távola 
Uma folha de papel, já amarelada, com uma marca de clip enferrujado, no fundo de uma pasta com vários textos, trouxe essa reflexão. Apontava que fazia parte do texto Um veículo forte à espera de programas criativos, veiculado em Cadernos de Jornalismo, $n^{\circ}$. 1, p. 16 et seq., do Sindicato dos Jornalistas Profissionais, Porto Alegre.

Um bom motivo para iniciar as discussões finais sobre este trabalho. Certamente falando de rádio, o texto se referia às modificações impostas a esse veículo de comunicação, sobretudo depois da chegada da televisão. Essas modificações exigidas ao rádio, dizia o autor, definiram um processo de especialização que the permitisse arregimentar e conservar um público heterogêneo, tanto do ponto de vista econômico, quanto do ponto de vista cultural.

À luz dos conceitos ensinados por Milton Santos e revisitados no primeiro capítulo desta dissertação, o rádio e, em especial a rádio comunitária, pode exercer um papel de extrema importância na construção da produção local de uma integração solidária, participando e articulando ações que visem o social, o cultural e o econômico. Esses espaços de horizontalidade a que o autor se refere evoluem e mudam continuamente e podem sobreviver à ação do Estado, já que este preocupa-se dominantemente com o desempenho das macro empresas.

É o espaço "banal", espaço do cotidiano e das solidariedades que impede o poder crescente e invasivo dos atores hegemônicos, porque se reconstitui permanentemente, porque se transforma, porque dialoga com 0 global e com o regional, mas vive o local, na busca do sentido de sua existência. É esse o espaço que através da ação comunicativa, apresenta as mais diversas manifestações de espontaneidade e da criatividade podendo construir os sentidos da realização plena da vida.

O objeto deste trabalho, processos comunicacionais sobre as culturas locais, buscou compreender a rádio comunitária de São Luis do Paraitinga, a 
única rádio da cidade que está autorizada a funcionar e sua participação nas ações culturais locais.

Como foi visto até aqui a cidade apresenta uma cultura rica, diversa e centenária que é orgulho de seus habitantes. Por outro lado, dispõe de poucos meios de comunicação de massa, e até por isso espera ações mais efetivas da rádio comunitária. Tendo conquistado a condição de estância turística há poucos anos tem procurado desenvolver atividades para atrair turistas para suas festas como meio de subsistência que, neste momento é ainda alternativa, mas que se pretende seja a principal, na opinião dos atores culturais da cidade.

Suas festas tradicionais atraem pessoas da região e até mesmo de grandes centros, como São Paulo, e as mais freqüentadas são o Carnaval e a Festa do Divino Espírito Santo. São importantes fontes de renda, porém é nessas festas que os luizenses resgatam sua identidade e comungam suas motivações socialmente relevantes. As manifestações culturais de São Luis do Paraitinga, como outras festas populares em outras localidades, têm o seu cerne no interior da sociedade civil, cujas instituições mobilizam o povo para o processo de celebração. Essa participação alimenta as festas porque fortalece o imaginário cultural. Sem a iniciativa de grupos sociais organizados que codificam e difundem as festas, elas não se configurariam como atos culturais.

Para Beltrão, a gênese da festa localiza-se no imaginário coletivo, sendo resgatada periodicamente através dos fluxos de comunicação interpessoal (grupos de parentesco, vizinhança, trabalho). Elas desencadeiam iniciativas de celebração, apropriadas pelas instituições sociais (escola, igreja, empresa, governo). Essa "intermediação" suscita o interesse dos veículos de difusão coletiva, produzindo comunicação massiva, o que mobiliza os indivíduos para participar dos atos comemorativos. Ao participar das festas as pessoas introjetam imagens, que irão nutrir o imaginário da sociedade a que pertencem e que se reativa sempre. ${ }^{102}$

\footnotetext{
${ }^{102}$ Luiz BELTRÃO, Folkcomunicação: a comunicação dos marginalizados, p. 2-7.
} 
Em São Luis sempre é festa, a mobilização dos indivíduos para suas manifestações culturais parece intrínseca do povo. Os poucos meios de comunicação de que dispõe são suficientes para mantê-lo em clima de festa. A Rádio Paraitinga, com seu alcance, poderia fazer mais.

São Luis do Paraitinga é uma cidade que parece ainda estar preservada dos efeitos dos meios de comunicação de massa. Não há jornal local, não são muitos os que têm condições de assinar os jornais de grande circulação, nem mesmo a rádio e o apresentador do único programa jornalístico têm acesso a jornais. Poucos são os que têm acesso à internet, seja porque não possuem o computador, seja porque não dispõem de recurso para uso de locais que disponibilizam o equipamento, a própria Rádio Paraitinga não tem internet; não há cinema ou teatro na cidade e o número de locadoras de vídeos e DVD`s é pequeno. A televisão continua representando a grande mídia massiva, disputada pelo rádio e, neste caso, efetivamente pela rádio comunitária.

A pesquisa junto aos habitantes da cidade denuncia forte audiência da Rádio Paraitinga, demonstra que embora outras emissoras sejam ali ouvidas ela é a que detém a preferência da população. Sua principal concorrente, a Band Vale, pertence à Rede Bandeirantes de Rádio e Televisão, portanto a emissora que neste cenário representa a mídia hegemônica nessa região. Como tal, defende interesses comerciais de oligopólios cuja programação poderia estar ameaçando as diversidades culturais da região. Outras emissoras citadas, dada a baixíssima audiência, não representam ameaça para a audiência da Rádio Paraitinga nem à preservação da cultura da cidade.

No entanto, os resultados podem sinalizar que a Band Vale representa um poder pouco ameaçador para as manifestações culturais tradicionais de São Luis do Paraitinga, exercendo fraca influência na configuração do imaginário social, hábitos, crenças e estilo de vida da comunidade luizense. Desta forma, pode estar fomentando muito pouco, nesta cidade, a febre do consumo dos mercados mundiais. 
Por ter sua sede fora do espaço da cidade, portanto distante do espaço de ação comunitária, teria provavelmente, em conseqüência, pouca sintonia e conformidade com o sentido da vida da cidade de São Luis. Citações espontâneas dos entrevistados trouxeram informação de que a TV Vanguarda, a líder da região, costuma anunciar as festas da cidade, mas em flashs de pouquíssimos minutos, em meio ao noticiário da região.

Conforme as considerações de Milton Santos, revisitadas no capítulo 1 desta dissertação, pode-se inferir também que tanto a televisão quanto a rádio Band Vale usam essa cidade, assim como outras da região, de forma pragmática com interesses puramente comerciais. Contudo, essa audiência especialmente a radiofônica da Band Vale pela cidade, pode estar garantindo a dialética, que como foi visto com Stuart Hall, é necessária para se pensar uma nova articulação entre o global e o local em São Luis do Paraitinga.

O essencial nessa relação é um estado de contínua tensão, de relacionamento, de influência e antagonismo com a cultura dominante. O que importa não são os objetos culturais historicamente determinados, mas o estado do jogo das relações culturais que assume diversas formas: pela incorporação, pela distorção, pela resistência, pela negociação e pela recuperação. A transformação que resulta desse jogo de relações é inevitável e assegura ao mesmo tempo a incorporação de novas culturas e a resistência das tradições.

A vinheta da Band Vale - Música e Informação - pode atrair os ouvintes para se inteirarem do que se passa nos âmbitos nacional e internacional, inferindo-se que esse jogo pode estar se configurando sob a forma da incorporação. Essa hipótese é reforçada pelo fato de que a Rádio Paraitinga não tem na sua programação um programa de jornalismo que possa fazer frente a essa atuação da concorrente. A análise qualitativa da pesquisa mostra que nas citações dos pesquisados esse fato foi trazido como uma das críticas à atuação da Paraitinga. 
Há que se registrar que embora o locutor Daniel Tucci, apresentador do Jornal Paraitinga, se empenhe na produção e apresentação do programa, reconhece a deficiência e aponta as limitações da emissora que o impedem de realizar uma produção mais adequada, conforme relatado em sua entrevista.

No entanto, por princípio, a rádio comunitária deve priorizar as questões da comunidade onde está inserida. Seu programa de radiojornalismo deveria ser acentuadamente local, o que não acontece com Jornal Paraitinga. $A$ análise do conteúdo do programa denuncia uma preocupação com o global, com trazer as notícias do que se passa fora dos limites da cidade, inclusive do noticiário internacional. Os fatos da cidade são apresentados durante a programação, como boletins informativos, e os dados de observação demonstram que sejam pouco ou nada comentados.

Os programas que tendem a priorizar os fatos da cidade são o Viva a Vida, no qual a apresentadora Fia abre espaço para debates e em geral faz críticas à vida política e social e, eventualmente, o Paraitinga da Saudade, através das crônicas sobre a cidade que o locutor Benedito Domingos produz e apresenta.

As análises dos resultados obtidos nas diversas fases do trabalho de campo sugerem que a Rádio Paraitinga não se caracteriza como uma rádio genuinamente comunitária. Os indicativos de uma atuação híbrida - ora comunitária, ora com características de rádio comercial - são fortemente reforçados por vários aspectos.

Uma análise da programação da emissora mostra que ela é basicamente musical, alguns programas ao vivo, mas na maior parte do tempo apresenta programas musicais gravados. Nos intervalos, os comerciais apoios culturais das lojas da cidade: supermercados, lojas de material de construção, farmácias, restaurantes, hotéis e pousadas, consultórios de profissionais liberais, entre outros. Nas entrevistas com os locutores levantouse que esses apoios culturais são contribuições em dinheiro, e de acordo com o diretor André Luis, não cobrem as despesas da emissora. 
Nos intervalos da programação, "comerciais" e algumas notícias da cidade, voltadas quase sempre para anunciar alguma festa na cidade ou na zona rural. Muito pouco se escuta sobre utilidade pública, seja anunciando campanhas de saúde, seja qualquer outro serviço de utilidade à comunidade.

No entanto, comunitária ou híbrida, é inegável, embora tímido ainda, o papel que a emissora desempenha nas manifestações culturais da cidade. A análise do conjunto de dados obtidos na pesquisa de campo demonstra que esse papel é reconhecido pelos ouvintes, no entanto, esperam mais da sua única emissora. Reconhecem que por ser uma rádio pequena, deva ter dificuldades, porém sabem que é comunitária e esperam dela ações para a comunidade.

Como foi visto com Peruzzo, nos capítulos anteriores, várias são as características que definem uma mídia comunitária. A Rádio Paraitinga necessita rever sua atuação e introduzir ações que melhor atendam à sua concessão e aos seus ouvintes. Não é apenas o alcance limitado em termos de cobertura e audiência que define uma rádio comunitária, é principalmente sua atuação e sua forma de gestão. Falta-lhe talvez um apoio mais efetivo da comunidade, uma real participação das pessoas da comunidade que devem ser protagonistas dos processos comunicacionais por ela propiciados.

Numa rádio comunitária o receptor pode se tornar emissor, o cidadão comum pode produzir as mensagens, cujos conteúdos devem referir-se às necessidades de interesse local, seja no que diz respeito às artes, à cultura ou à outras necessidades apontadas pela sociedade. Ganharia a emissora e seus ouvintes se mais cidadãos luizenses participassem da programação da rádio.

Como citado no capítulo 1, de acordo com Lopez Vigil, as rádios comunitárias não têm por objetivo fazer algo para as comunidades, a própria comunidade deverá fazer algo para si mesma, controlando os seus meios de comunicação. 
A Rádio Paraitinga deveria divulgar mais os assuntos específicos da comunidade, dos movimentos coletivos e de grupos e segmentos da cidade. Procurar interagir com os grupos sociais organizados e com eles articular as ações sociais que realizam para cumprir com a meta de contribuir para o desenvolvimento comunitário. As festas da zona rural deveriam ter cobertura da rádio da cidade, porque há alcance para algumas localidades e porque há interesse dos luizenses que assim seja feito.

A direção da rádio deveria buscar saber as razões pelas quais seus ouvintes não têm uma participação mais efetiva e envidar esforços para que essa aproximação aconteça o quanto antes. Neste momento parece não haver uma ameaça à audiência da emissora, seja porque a Band Vale não tem boa sintonia em algumas partes da cidade, seja porque ainda não surgiu uma nova emissora, mesmo que não oficial, para the fazer frente. Provavelmente, bastaria uma mudança de local na instalação de antena transmissora de alguma emissora regional para que a Paraitinga começasse a sentir-se ameaçada.

Sua gestão deveria ser coletiva, organizando um conselho comunitário, de forma a demonstrar transparência na administração e autonomia em relação ao poder público. Desta forma, acredita-se que a Rádio Paraitinga poderia realmente ser reconhecida por seus ouvintes como a sua "radinha querida", como carinhosamente uma ouvinte pesquisada a denominou.

Mas, observa-se que a consciência está em gestação e muito pode ser feito daqui para frente para que a Rádio Paraitinga possa se construir como um ator mais atuante nos processos comunicacionais da cidade e, desta forma, participar do projeto da comunidade: preservar suas tradições, articulá-las com o presente e desejar o futuro. 


\section{BIBLIOGRAFIA}

\section{Bibliografia}

ADORNO, Theodor W. Conferência sobre lírica e sociedade. Coleção Os Pensadores, vol. 4. São Paulo: Abril, 1978. 
Sobre música popular. In: COHN, Gabriel (org). Theodor Adorno. São Paulo: Ática, 1986.

ARAÚJO, Alceu Maynard. Cultura Popular Brasileira. São Paulo: Editora Melhoramentos, 1973.

ARNHEIM, Rudolf. A estética radiofónica. Barcelona: Gustavo Gilli, 1980.

Arte e percepção visual. São Paulo: Pioneira, 1991.

BALSEBRE, Armand. El Lenguaje Radiofónico. Madrid, Ediciones Cátedra, 1994.

BARBOSA FILHO, André, PIOVESAN, Angelo e BENETON, Rosana (orgs.). Rádio: Sintonia do Futuro. São Paulo: Paulinas, 2004.

BARBOSA, Lívia. O jeitinho brasileiro. Rio de Janeiro: Campus, 1992.

BAUDRILLARD, Jean. Para uma economia política do signo. São Paulo: Martins Fontes, 1983.

. Simulacros e Simulação.Lisboa: Relógio D’agua, 1991.

. A sociedade de consumo. Rio de Janeiro: Elfos, 1995.

A sombra das maiorias silenciosas. São Paulo: Brasiliense, 1990.

BELTRÃO, Luiz. Folkcomunicação: a comunicação dos marginalizados.São Paulo: Cortez, 1980.

BENJAMIN, Roberto. O imaginário popular como fator de desenvolvimento da arte, Revista Comunicação \& Política, nº 3. Rio de Janeiro: Cebela, 2002.

BENJAMIN, Walter. A obra de arte na época da sua reprodutividade técnica. In Obras Escolhidas, v. 1. São Paulo: Brasiliense, 1985. 
. Dois tipos de popularidade. In: Documentos de cultura documentos de barbárie. São Paulo: EDUSP/CULTRIX, 1986.

BOLLE, Willi. Fisiognomia da metrópole moderna. São Paulo: EDUSP/FAPESP, 1994.

BOURDIEU, Pierre. "O campo científico." In: ORTIZ, Renato. Pierre Bourdieu. Coleção Grandes Cientistas Sociais. São Paulo: Ática, 1983.

La reproducion. Barcelona: Laia, 1977.

et al. A profissão de sociólogo. Petrópolis: Vozes, 1999.

BRECHT, Bertolt. Teorias de la Radio - sugerencias a los directores artísticos de la rádio. In: El compromisso en la literatura y arte. Barcelona: Península, 1973.

CANEVACCI, Massimo. Antropologia da comunicação visual. São Paulo: Brasiliense, 1990.

CAPPARELLI, Sérgio. Comunicação de massa sem massa. São Paulo: Cortez, 1982.

.\& STUMPF, Ida. "El campo académico de la comunicación, revisitado." In: LOPES, M. I. V \& FUENTES, R. (comps.) Comunicación; campo y objeto de estudio. Guadalajara: Iteso, 2001.

CASCUDO, Luis da Câmara . Folclore do Brasil (pesquisas e notas). Rio de Janeiro: Editora Fundo de Cultura S/A, 1967.

CITELLI, Adilson. Aprender e ensinar com textos não escolares. São Paulo: Fapesp/CNPq/USP-FFLCH-Pró-Reitoria de Pesquisa, 1994. 
. (org.) Outras linguagens na escola. São Paulo: Cortez, 2000.

. (org.) Comunicação e educação; a linguagem em movimento. São Paulo: Editora Senac São Paulo, 2000.

Comitê Pró-Associação para o Desenvolvimento Cultural e Ambiental de São Luis do Paraitinga. "São Luis, o ano inteiro". São Luis do Paraitinga: Geic, Vogal, 1997.

CORTELA, Mário S. A escola e o conhecimento: fundamentos epistemológicos e políticos. 4. ed. São Paulo: Cortez, 2001.

DEL BIANCO, Nélia R. \& MOREIRA, Sônia Virgínia (orgs.). Rádio no Brasil; tendências e perspectivas. Rio de Janeiro / Brasília: Eduerj / UnB, 1999.

DELLA VOLPE, Galvano. Esboço de uma história do gosto. São Paulo: Mandacaru, 1989.

DOWNING, John D. H. Mídia Radical - Rebeldia nas Comunicações e Movimentos Sociais. São Paulo: Editora Senac, 2002.

DURKHEIM, E. As regras do método sociológico. Tradução Maria Isaura P. de Queiroz. São Paulo: Nacional, 1960.

ECO, Umberto. "James Bond: uma combinatória narrativa." In: BARTHES, R. et al. Análise estrutural da narrativa. Petrópolis: Vozes, 1976.

ESTEVAM, Carlos. A Questão da Cultura Popular. Rio de Janeiro: Civilização Brasileira, 1968.

FEATHERStONE, Mike. Cultura de Consumo e Pós-Modernismo. São Paulo: Studio Nobel, 1990.

O desmanche da cultura. São Paulo: Nobel, 1999. 
FEDERICO, Maria Elvira Bonavita. História da comunicação, rádio e tv no Brasil. Petrópolis: Vozes, 1982.

FERNANDES, Florestan. "Sobre o Folclore", in O folclore em Questão. São Paulo: HUCITEC, 1978.

FERREIRA, Maria Nazareth. Globalização e Identidade Cultural na América Latina. São Paulo: CEBELA, 1995.

(org.). Cultura, Comunicação e Movimentos Sociais. São Paulo: CELACC: ECA/USP, 1999.

- Identidade Cultural: Resistência ou Dependência. (notas acerca da construção da identidade cultural) in Culturas da Comunicação. Revista Comunicação e Política. Rio de Janeiro: CEBELA, 1997.

. Culturas da Comunicação. III Simpósio Internacional do CEBELA. 1997.

- As Festas Populares na Expansão do Turismo - a experiência italiana. São Paulo: Arte Ciência, 2001.

FOUCALT, Michel. A ordem do discurso. São Paulo, Edições Loyola, 1996.

FREIRE, Paulo. Pedagogia do oprimido. Rio de Janeiro: Paz e Terra, 1983. - Pedagogia da autonomia; saberes necessários à prática educativa. Coleção Leitura. Rio de Janeiro: Paz e Terra, 1997.

FREITAG, B. A teoria crítica: ontem e hoje. São Paulo: Brasiliense, 1990.

Fundação SEADE. Guia Cultural do Estado de São Paulo, da Secretaria de Estado da Cultura, ano 2001, volume referente aos municípios: $\mathbf{S}-\mathrm{Z}$. 
GARCIA CANCLINI, Nestor y RONCAGLIOLI, Rafael. Cultura Transnacional y Culturas Populares. Lima: Ipal, 1998.

- Cultura y comunicación: entre lo global y lo local. La Plata: Universidad Nacional de La Plata, 1997.

GARDNER, Howard. Estruturas da mente: a teoria das inteligências múltiplas. Porto Alegre: Artes Médicas, 1996.

GIDDENS, Anthony. As conseqüências da modernidade. São Paulo: Ed. Unesp,1991.

. Un mundo desbocado. Madrid: Taurus, 2000.

GRAMSCI, Antonio. Literatura e Vida Nacional. Rio de Janeiro: Civilização Brasileira, 1968.

GREENFIELD, Patrícia M. O desenvolvimento do raciocínio na era da eletrônica; os efeitos da tevê, computadores e videogames. São Paulo: Summus, 1988.

GUIMARÃES, Gláucia. TV e escola; discursos em confronto. São Paulo: Cortez, 2000.

GULLAR, Ferreira. Cultura Posta em Questão, Rio de Janeiro: Civilização Brasileira, 1965.

GUTIERREZ, Francisco. Linguagem total: uma pedagogia dos meios de comunicação. São Paulo: Summus, 1978.

HALL, Stuart. A identidade cultural na pós-modernidade. Rio de Janeiro: DP\&A, 1999. 
. Da Diáspora: identidade e mediações culturais. Belo Horizonte:

UFMG, 2003.

HARTMANN, Jorge \& MUELLER, Nélson (org.). A comunicação pelo microfone. Petrópolis: Vozes, 1998.

HARVEY, David. Condição pós-moderna. São Paulo: Loyola, 1993.

HAUSSEN, Doris Fagundes. Rádio Brasileiro: uma história de cultura, política e integração. In: BARBOSA FILHO, André, PIOVESAN, Angelo e BENETON, Rosana (orgs.). Rádio: Sintonia do Futuro. São Paulo: Paulinas, 2004.

HUERGO, Jorge Alberto \& FERNÁNDEZ, Maria Belén. Cultura escolar, cultura mediática; intersecciones. Bogotá: Universidad Pedagógica Nacional, Santafé, 2000.

IANNI, Octavio. Globalização: novo paradigma das ciências sociais. In: Estudos Avançados. São Paulo: USP/IEA, vol. 8, 21, 1994.

. A Dialética da Globalização. In Teorias da Globalização. Rio de Janeiro: Civilização Brasileira, 1999.

. Teorias da Globalização. Rio de Janeiro: Civilização Brasileira, 1998. JAMESON, Frederic. "Notas sobre a globalização como questão filosófica." In: A cultura do dinheiro; ensaios sobre a globalização. Petrópolis: Vozes, 2001.

KUNSCH, Margarida M. K. (org.). Comunicação e educação; caminhos cruzados. São Paulo: Loyola, 1986.

LEFEBVRE, Henri. Lógica Formal/Lógica Dialética. Rio de Janeiro: Civilização Brasileira, 1983.

LÉVY, Pierre. As tecnologias da inteligência e o futuro do pensamento na era da informática. São Paulo: Editora 34, 1994. 
. A inteligência coletiva; por uma antropologia do ciberespaço. São Paulo: Editora 34, 1998.

LOPES, Maria Immacolata V. Pesquisa em comunicação. 6. ed. São Paulo: Loyola, 2002.

. "Por um paradigma transdisciplinar para o campo da comunicação." In: DOWBOR et al. (orgs.) Desafios da comunicação. Petrópolis: Vozes, 2001.

. "O campo da comunicação: reflexões sobre seu estatuto disciplinar." In: Revista USP, 48, 2001.

. "A institucionalização dos estudos de Comunicação no Brasil." In: LOPES, Maria Immacolata V.\& BUONANNO, M. (orgs.). Comunicação no Plural. Estudos de Comunicação no Brasil e na Itália. São Paulo: Educ/Intercom, 2000.

. "Uma metodologia para a pesquisa das mediações." In: Coletânea Mídias e Recepção 2000. Porto Alegre: Unisinos/Compós, 2000.

. "La investigación de la comunicación: cuestiones epistemológicas, teóricas y metodológicas." In: Diálogos de la Comunicación, 56. Lima: Felafacs, 1999.

. "Estratégias metodológicas da pesquisa de recepção." In: Intercom Revista Brasileira de Comunicação, vol. XVI, 2, São Paulo: 1993.

MACHADO, Arlindo. A televisão levada a sério. São Paulo: Editora Senac São Paulo, 2000.

MARGULIES, Mário. Reproducción social de la vida y reproducción del capital. México: Nueva Antropologia, 1990. 
MARTIN-BARBERO, Jesús. Dos meios às mediações: comunicação, cultura e hegemonia. Rio de Janeiro: UFRJ, 1997.

- Retos a la investigación de comunicación en América Latina. In: FERNANDEZ, F. et al. Comunicación y teoría social. México: UNAM, 1984.

. La telenovela en Colombia: televisión, melodrama y vida cotidiana. In: Dialogos de la Comunicación. Lima: Felafacs, 1987.

MARX, K. El Capital. Mexico:Fondo de Cultura Económica, 1973 (3v).

- Elementos fundamentales para la critica de la Economia Política. Mexico: Siglo XXI, 1971.

. e ENGELS, F. La ideología alemana. Traducción por Wenceslao Roces. Buenos Aires: Pueblo Unidos, 1973.

MATTELARD, Armand \& MICHĖLE. História das teorias da comunicação. São Paulo: Loyola, 2000.

MEJIA, Alberto Lopes. "Um novo conceito de comunicação: o destinatário é o sujeito." In Revista Proposta, n. 43, Rio de Janeiro: Fase, 1989.

MENDONÇA Maria Luisa. Comunicação e Cultura: um novo olhar. In Revista Novos Olhares. São Paulo: ECAUSP, 1998.

MONTESQUIEU, Charles-Louis. Sul gusto. Gênova: Casa Editrice Marietti, 1990.

MORAES, Dênis de. O Planeta Mídia - Tendências da Comunicação na Era Global. Campo Grande: Letra Livre, 2001. - (org.). Por uma outra comunicação - mídia, mundialização cultural e poder. Rio de Janeiro/São Paulo: Ed. Record, 2003. 
MORAGAS, Miguel. Ubicación epistemológica e ideológica de la comunicación de masas. In: FERNANDEZ, F. et al. Comunicación y teoría social. México: Unam, 1984.

MOREIRA, Sonia Virginia. Rádio, mídia local em transformação. In Revista Nós da Escola, Ano 3 - 2005.

MORIN, Edgar. A cabeça bem-feita. Rio de Janeiro: Bertrand Brasil, 2000.

.Ciência com consciência. Lisboa: Europa/América, 1982.

MUNIZ, Sodré. O monopólio da fala. Rio de Janeiro: Vozes, 1984.

OROZCO GOMES, Guillermo. La investigación en comunicación desde la perspectiva qualitativa. La Plata: Un. Nacional de la Plata, 1996.

ORTIZ, Ángel Miguel \& MARCHAMALO, Jesús. Técnicas de comunicación en radio, la realización radiofónica. Barcelona: Paidós, 1997.

ORTIZ, Renato. A revolução urbana. Belo Horizonte: Humanitas, 2002.

. Cultura Brasileira e Identidade Nacional. São Paulo: Cortez, 2001.

. A Moderna Tradição Brasileira: cultura brasileira e a indústria cultural. São Paulo: Brasiliense, 1988.

PERUZZO, Cicília M.Krohling. Direito à comunicação comunitária, participação popular e cidadania. In Ciências da la comunicación, Revista año II, $n^{\circ} 3$. São Paulo: ALAIC, 2006.

. Midia Local e Suas Interfaces com a Mídia Comunitária. In ANUÁRIO UNESCO/UMESP. São Bernardo do Campo: UMESP, 2003. 
. Participação nas Rádios Comunitárias no Brasil. Texto apresentado no

GT Cultura e Comunicação Popular, XXI Congresso Brasileiro de Ciências da Comunicação. Recife: 1998.

(org). Vozes Cidadãs: aspectos teóricos e análises de experiências de comunicação popular e sindical na América Latina. São Paulo: Angellara Editora, 2004.

PFROMM NETTO, Samuel. Telas que ensinam; mídia e aprendizagem - do cinema ao computador. Campinas: Alinea, 1998.

PORTELLI, H. Gramsci y el bloque histórico. Buenos Aires: Siglo XXI, 1974.

QUIJANO, Aníbal. Estética de la Utopia. In Revista Comunicação e Política na América Latina, ano 10, n 13. São Paulo: 1991.

RODRIGUES, A.D. Estratégias da Comunicação. Lisboa: Presença, 1990.

ROMERO, Jaime Astudillo. Globalización e Integración Cultural Regional. In:

SANTOS, Milton. Folha de São Paulo, Caderno Mais, 24-01-2001.

. O lugar e o cotidiano. In: Da natureza do espaço - técnica e tempo, razão e emoção. São Paulo: HUCITEC, 1996.

. Por uma Outra Globalização - do pensamento único à consciência universal. São Paulo: Record, 2002.

SEVERINO, Antonio Joaquim. Metodologia do Trabalho Científico. São Paulo: Cortez Editora, 2001.

SILVERSTONE, Roger. Por que estudar a mídia? São Paulo: Loyola, 2002. 
SOARES, Ismar O. Sociedade da informação ou da comunicação. São Paulo: Cidade Nova, 1996.

SODRÉ, Muniz. As Estratégias Sensíveis - afeto, mídia e política. Rio de Janeiro: Vozes, 2006.

SOUZA SANTOS, Boaventura. Pela mão de Alice - o social e o político na pósmodernidade. 4ª ed., Lisboa: Edições Afrontamento, 1995.

SOUZA, Mauro Wilton. Práticas de recepção mediática como práticas de pertencimento. Revista Novos olhares. São Paulo: 2002.

. (org.) Sujeito, o lado oculto do receptor. São Paulo: Brasiliense, 1994.

SPEZ, Lucien. Crítica da comunicação. São Paulo: Loyola, 1994.

STAM, Robert. Bakhtin. São Paulo: Ática, 1992.

SWINGEWOOD, Alan. O mito da cultura de massa. Rio de Janeiro: Interciências, 1980.

TÁVOLA, Arthur da. Um veículo forte à espera de programas criativos. In Cadernos de Jornalismo, $\mathrm{n}^{\circ}$. 1, p. 16 et seq., Sindicato dos Jornalistas Profissionais. Porto Alegre: s/d.

THIOLLENT, Michel. Critica metodológica, investigação social e enquete operária. São Paulo: Polis, 1980.

TRINDADE, L.S. As raízes ideológicas das teorias sociais. São Paulo: Ática, 1978.

URIBE, Esmeralda Villegas. Alto-Falantes: formas autônomas de expressão e de desenvolvimento local, in Vozes Cidadãs: aspectos teóricos e análises de 
comunicação popular e sindical na América Latina. Cicília M. Krohling Peruzzo (org.). São Paulo: Angellara Editora, 2004.

VATTIMO, Gianni. A sociedade transparente. Lisboa: Relógio d' Água, 1992.

WALLERSTEIN, Immanuel et al. Para abrir as ciências sociais. Lisboa: EuropaAmérica, 1996.

WEBER, M. Economia y Sociedade. Mexico: ECE, 1964.

WOLF, Mauro. Teorias da comunicação. Lisboa: Presença, 1987.

\section{Sites}

São Luis do Paraitinga - www.saoluizdoparaitinga.sp.gov.br

Site da Fundação SEADE - www.seade.gov.br

Site do IBGE - www.ibge.gov.br

MORAES, Denis de. Notas sobre o imaginário e hegemonia cultural, http//www.uff.br/msticii/cc76.htm.

Sodero Toledo Serviços Educacionais S/C http://www.valedoparaiba.com www.estudosvaleparaibanos.com.br

www.cemina.org

http://comunica.org.apasionados/pdf/radioapasionados/pdf

www.amarc.org

http://alc.amarc.org

www.abraconet.org.br

www.tvcultura.com.br/reportereco/materia.asp?materiaid=264 


\section{ANEXOS}




\section{ANEXO I}

\section{Mapa do Vale do Paraíba}

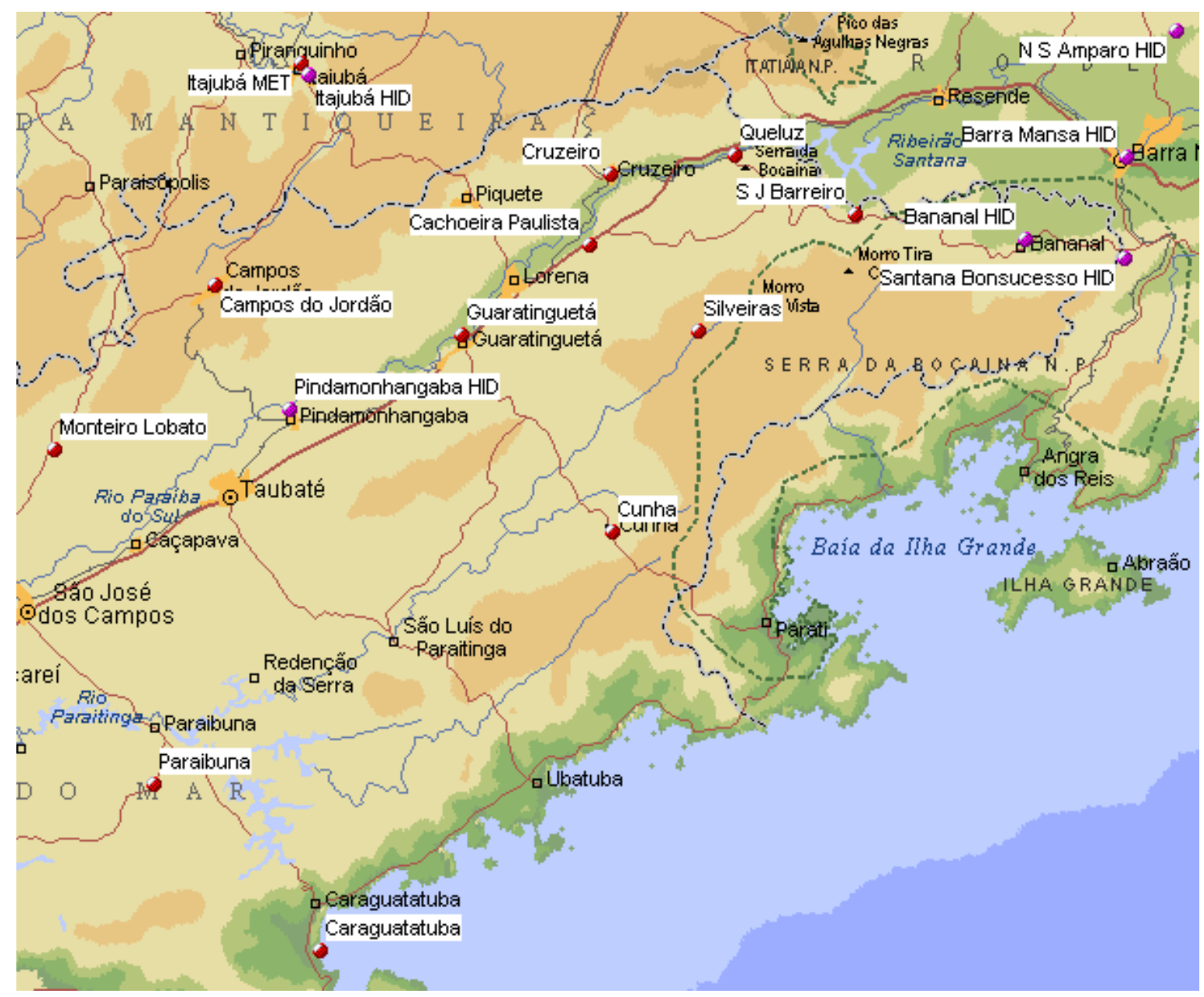




\section{ANEXO II \\ PESQUISA P/ MESTRADO PELA UNIVERSIDADE DE SÃO PAULO \\ ESCOLA DE COMUNICAÇÕES E ARTES - DEPTO CTR}

Responsável: Rosana Beneton

São Luis do Paraitinga - Cultura e Rádio Comunitária

Nome:

Sexo: ( ) F ( ) M Idade:

anos

End.

Quantos aparelhos de rádio:

Escolaridade:

Quantas pessoas moram na casa/parentesco/idade/escolaridade?

Nasceu na cidade? ( ) S ( ) N Se não, há quanto tempo mora aqui?

De quais festas da cidade você participa?

( ) Encontro de Folia de Reis

( ) Temporada de Inverno

( ) Festival de Marchinhas de Carnaval

( ) Romaria dos Cavaleiros

( ) Carnaval

( ) Semana Dr. Oswaldo Cruz

( ) Procissão Sexta-feira Santa

( ) Festa do Padroeiro "São Luis de

Tolosa

( ) Sábado de Aleluia

( ) Domingo de Páscoa

( ) Big Biker

( ) Aniversário da Cidade (08/05)

( ) Festa do Divino

( ) Semana Elpídio dos Santos

( ) Corpus Christi”"

( ) Festival de Música Junina

( ) Festival de Música Raiz Sertaneja "Mestre Dito Geraldo

( ) Festa de São Pedro

( ) Festa do Saci

( ) Natal

( ) Reveillon

2)Qual (is) é (são) a(s) mais importante (s)?

( ) Encontro de Folia de Reis

( ) Temporada de Inverno

( ) Festival de Marchinhas de Carnaval

( ) Romaria dos Cavaleiros

( ) Carnaval

( ) Procissão Sexta-feira Santa

( ) Semana Dr. Oswaldo Cruz

Tolosa

( ) Festa do Padroeiro "São Luis de
( ) Sábado de Aleluia
( ) Big Biker 
( ) Domingo de Páscoa

( ) Aniversário da Cidade (08/05)

( ) Festa do Divino

( ) Corpus Christi"

( ) Festival de Música Junina

( ) Festa de São Pedro
( ) Semana Elpídio dos Santos

( ) Festival de Música Raiz Sertaneja "Mestre Dito Geraldo

( ) Festa do Saci

( ) Natal

( ) Reveillon

3) Como fica sabendo dessas festas e suas atividades?
( ) pela televisão
( ) por amigos
folhetos
( ) pelo rádio. Qual (is)

( ) outro, qual?

4) Você participa das festas? De que forma? （ ) da preparação （ ) apenas participando

5) Que rádios você escuta aqui na cidade?
( ) Band (Bandeirantes)
( ) Metropolitana
( ) Jovem Pan
( ) Paraitinga
( ) Difusora
( ) Outra, qual?

6) Qual a que você mais ouve/ prefere?

7) Você ouve a Rádio Paraitinga? ( ) Sim （ ) Não, por quê?

8) O que eu mais gosto na Rádio Paraitinga é que ela é da cidade e fala dos assuntos da cidade.

( ) Concordo totalmente

( ) Concordo em parte

( ) Discordo totalmente

( ) Discordo em parte

9) Quais os programas da Rádio Paraitinga que você prefere?
( ) 07h00/09h00 - Programa Sertanejo
( ) 17h00/18h00 - Let's Rock
( ) 09h00/11h30 - Música Variada
( ) 18h00/18h30 - Terço
( ) 11h30/ - Jornal
( ) 19h00/ 21h00 - Musical
Romântico
( )
( ) 13h00/16h00 - Musical - POP
( ) 16h00/17h00 - Seleção Brasileira
( )
( )
( ) 00h00/01h00 - Rock na Madrugada

$$
\text { ( ) 01h00/07h00 - Musical (gravado) }
$$

10) Quais dos serviços prestados pela Rádio Paraitinga já foram úteis pra você?

( ) notas sociais (casamento, festas, bailes, quermesses, etc.) 
( ) ajuda (desaparecimento de pessoas, achados e perdidos)

( ) oferta de empregos

( ) dicas de saúde

(

outros,

11) O que você não gosta na Rádio Paraitinga?

12) Como os locutores falam nos programas, que tipo de palavras eles usam e que mais têm a ver com seu jeito de falar?

13) Você já participou de algum programa da rádio? ( ) Não ( ) Sim Se sim, como?

( ) programa gravado

( ) programa ao vivo

( ) por telefone ( ) no estúdio ( ) por carta

14) A Rádio Paraitinga apóia as festas da cidade? （ ) Não ( ) Sim Se sim, como?

15) Se a Rádio Paraitinga não divulgasse ou participasse das festas, como você teria informações sobre as atividades dela?

Comentários extras do pesquisado: 
Observações do pesquisador:

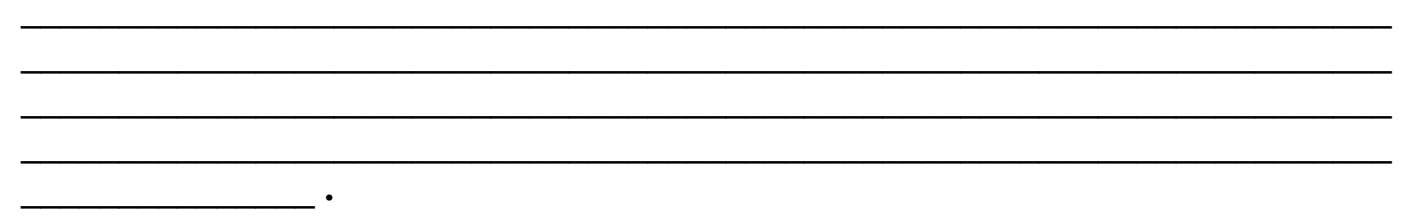

Pesquisador:

Data: __ I I 


\begin{abstract}
ANEXO III
PESQUISA PARA MESTRADO PELA UNIVERSIDADE DE SÃO PAULO

ESCOLA DE COMUNICAÇÕES E ARTES - DEPTO CTR
\end{abstract}

Resp. Rosana Beneton - São Luis do Paraitinga - Cultura e Rádio Comunitária

Nome:

Sexo: ( ) F ( ) M Idade:

anos

Profissão:

Religião:

Estado Civil:

Escolaridade:

End.

Quantas pessoas moram na casa/parentesco/idade/escolaridade?

Nasceu na cidade? ( ) S ( ) N Se não, há quanto tempo mora aqui?

1) Você participa das festas? ( ) N （）S De que forma? （ ) apenas freqüentando

( ) da preparação: ( ) prepara alimentos - doa/vende ( ) faz artesanato doa/vende

barracas

$$
\text { ( ) recolhe prendas ( ) toca instrumento ( ) trabalha nas }
$$

2) De quais festas da cidade você participa? Determinar a ordem de importância.

( ) Encontro de Folia de Reis

( ) Temporada de Inverno

( ) Festival de Marchinhas de Carnaval

( ) Carnaval

( ) Procissão Sexta-feira Santa

( ) Romaria dos Cavaleiros

Tolosa"

( ) Sábado de Aleluia

( ) Domingo de Páscoa

( ) Aniversário da Cidade (08/05)

( ) Festa do Divino

( ) "Corpus Christi"

( ) Festival de Música Junina

( ) Festa de São Pedro

( ) Semana Dr. Oswaldo Cruz

( ) Festa Padroeiro "São Luis de

( ) Big Biker

( ) Semana Elpídio dos Santos

( ) Festival de Música Raiz Sertaneja "Mestre Dito Geraldo"

( ) Festa do Saci

( ) Natal

( ) Reveillon 
( ) Festival Gastronômico

3) Como fica sabendo dessas festas e suas atividades?

$\begin{array}{ll}\text { ( ) pela televisão } & \text { ( ) por amigos }\end{array}$

folhetos

( ) pelo rádio. Qual (is) cartazes

( ) outro, qual?

4) Que rádios você escuta aqui na cidade?
( ) Band (Bandeirantes)
( ) Metropolitana
( ) Jovem Pan
( ) Paraitinga
( ) Difusora
( ) Outra, qual?

5) Qual a que você mais ouve/ prefere?

Por quê?

6) Você ouve a Rádio Paraitinga? （ ) Sim （ ） Não, por quê?

7) “O que eu mais gosto na Rádio Paraitinga é que ela é da cidade e fala dos assuntos da cidade".

( ) Concordo em parte

( ) Discordo totalmente ( ) Discordo em parte

Por

quê?

8) Quais os programas da Rádio Paraitinga que você prefere?

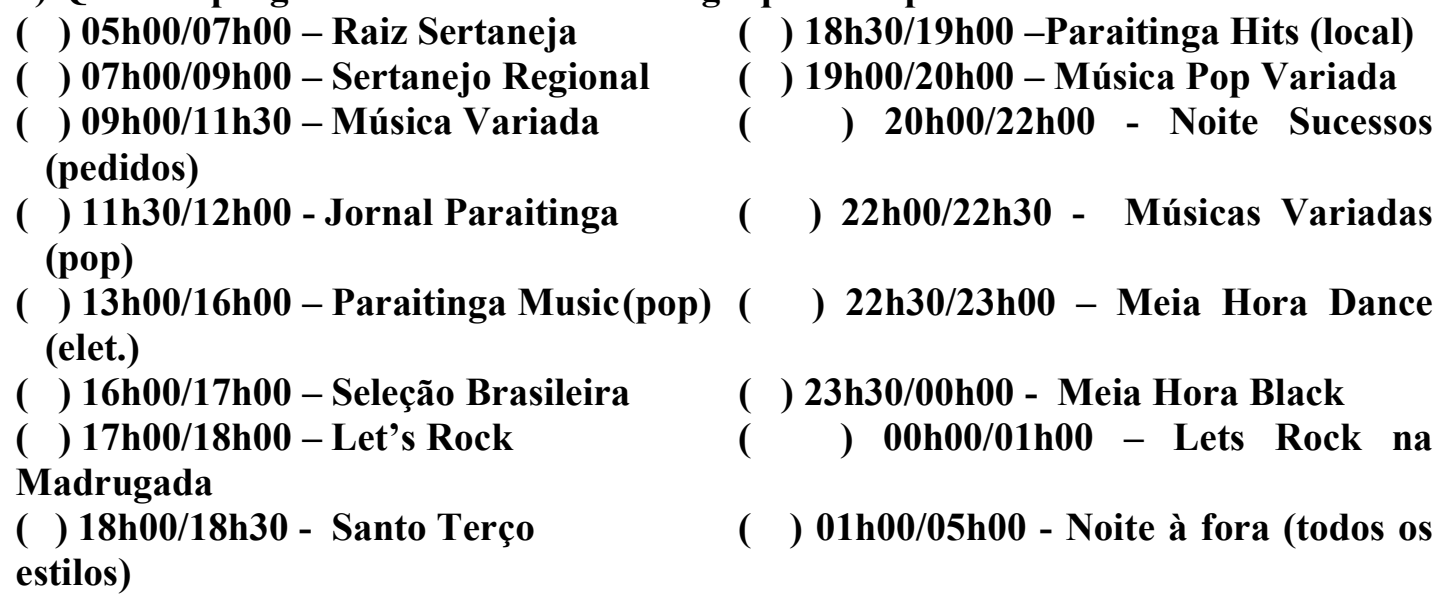

Especiais:

( )Anarquia Cultural $-5^{\mathrm{a}} \mathrm{s}-22 \mathrm{~h}$ às 00h $\quad$ ( ) Paraitinga da Saudade Sábados

( ) Estrada do Sertão - domingos 7 h30 às 9 h30

( ) Todos os Ritmos - domingos $12 \mathrm{~h}$ às $15 \mathrm{~h}$ 
Religiosos:

( )Voz da Paróquia - $6^{\mathrm{a}} \mathrm{s}-12 \mathrm{~h}$ às 13h ( ) Assembléia de Deus - 2 ${ }^{\mathrm{a}} \mathrm{s}$ e $5^{\mathrm{a}} \mathrm{s}-21 \mathrm{~h}$ às $22 \mathrm{~h}$

( ) Viva a Vida - domingos - 9h às $12 \mathrm{~h}$ (com a Fia)

( ) Luz Espírita - 6 $\mathrm{a}$ - 21h às 22h

9) Quais dos serviços prestados pela Rádio Paraitinga já foram úteis pra você?

( ) notas sociais (casamento, festas, bailes, quermesses, etc.)

( ) ajuda (desaparecimento de pessoas, achados e perdidos)

( ) oferta de empregos

( ) dicas de saúde, campanhas de vacinação

(

outros,

10) O que você não gosta na Rádio Paraitinga?

11) Levando em consideração como os locutores falam nos programas, que tipo de palavras ou expressões eles usam e que mais têm a ver com seu jeito de falar ou com o jeito da cidade?

12) Você já participou de algum programa da rádio? ( ) Não ( ) Sim Se sim, como?

( ) programa gravado

( ) programa ao vivo

Como foi sua participação:

( ) por telefone ( ) no estúdio ( ) por carta ( )pessoalmente Assunto:

13) A Rádio Paraitinga apóia as festas da cidade? ( ) Não ( ) Sim

Se sim, como?

( ) Divulgando com antecedência

( ) Informando sobre as atividades da festa 
( ) Orientando mudanças no cotidiano da cidade

14) É importante preservar as festas tradicionais da cidade? ( ) $N \quad$ ( ) $\mathrm{S}$ Se sim, por quê?

( ) continuidade das nossas tradições e da história da cidade

( ) o povo precisa das festas para se encontrar

( ) atrai gente de fora, melhora o comércio

15) O que mais ajuda para que as festas aconteçam todos os anos?

( ) divulgação pela televisão ( ) divulgação pelo rádio. Qual?

( ) cartazes e folhetos ( ) ação da igreja ( ) ação da Prefeitura

16) Qual a principal razão pela qual as pessoas da cidade participam das festas?

$-$

17) Quantos aparelhos de rádio você tem em casa?

Comentários extras do pesquisado:

Observações do pesquisador:

Pesquisador:

Data: 


\section{ANEXO IV}

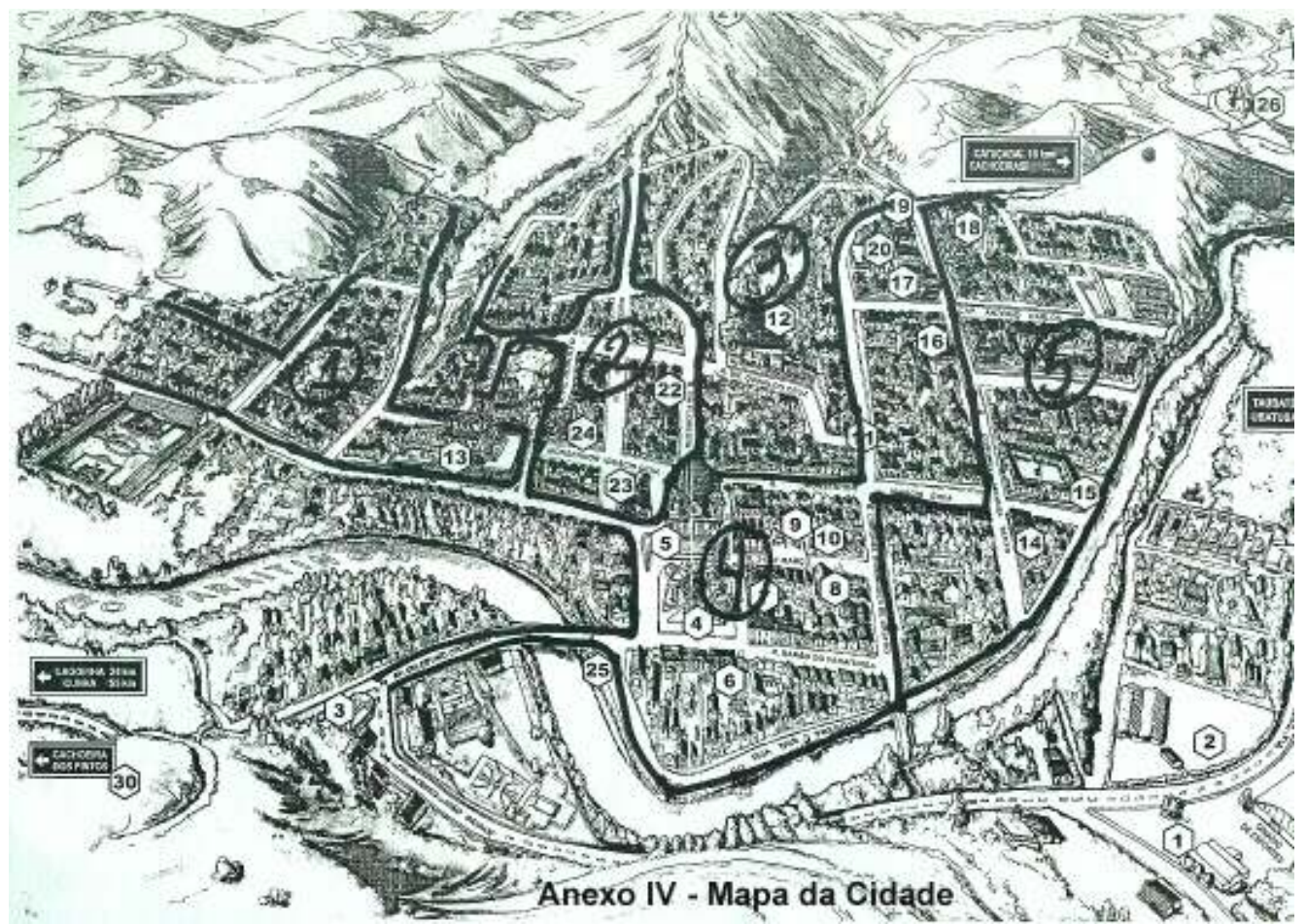




\begin{abstract}
ANEXO V
Tabulação Geral - Pesquisa em São Luis do Paraitinga
\end{abstract}

83 participantes, sendo 35 homens $-42,1 \%$ e 48 mulheres $-57,9 \%$

\title{
1) Você participa das festas?
}

$\begin{array}{lr}\text { Não - } & 6 \% \\ \text { Sim - } & 94 \%\end{array}$

Só freqüentando: $67,9 \%$

Preparando: $32,1 \%$

Prepara alimentos - doa/vende: $52 \%$

Recolhe prendas: $\quad 26 \%$

Toca instrumentos: $\quad 16 \%$

Trabalha nas barracas: $\quad 20 \%$

\section{2) De quais festas da cidade você participa?}

Não responderam : 3,6 \%

Não participa: 1

Participam: $\quad 95,1 \%$, sendo que $16,8 \%$ participa de todas

$\begin{array}{ll}\text { Festa do Divino } & 91,1 \% \\ \text { Carnaval } & 78,4 \% \\ \text { Festival Marchinhas de Carnaval } & 58,2 \% \\ \text { "Corpus Christi” } & 54,4 \% \\ \text { Procissão Sexta-Feira Santa } & 53,1 \% \\ \text { Aniversário da Cidade } & 50,6 \% \\ \text { Encontro Folia de Reis } & 49,3 \% \\ \text { Festival Música Junina } & 49,3 \% \\ \text { Festa do Padroeiro } & 49,3 \%\end{array}$

Depois:

Temporada de Inverno e Natal - $28 \%$

Festa de São Pedro, Festival Gastronômico, Sábado de Aleluia - com $27 \%$

Páscoa - $26 \%$

Festa do Saci, Reveillon - $23 \%$

Festival Música de Raiz - $20 \%$

Romaria dos Cavaleiros, Semana Dr. Oswaldo Cruz, Semana Elpídio dos

Santos $-17 \%$

Big Biker - $15 \%$ 
Ainda citadas fora do calendário oficial do ano:

Rodeio: $5 \%$

Festas de São Sebastião, São Benedito, Santa Cruz: todas com 1 citação cada.

Determinar a ordem de importância da festa para a cidade.

Não responderam: $38,5 \% \quad$ Responderam: $61,5 \%$

$1^{\circ}$ lugar

Festa do Divino: $47 \%$

Carnaval: $43 \%$

$2^{\circ}$ lugar

Festa do Divino: $37 \%$

Carnaval: $25 \%$

$3^{\circ}$ lugar

Festival Marchinhas de Carnaval: $10 \%$

Rodeio, Festa do Padroeiro $=8 \%$

$4^{\circ}$ lugar

Romaria dos Cavaleiros, Temporada de Inverno e "Corpus Christi": 8 \%

Festival de Música Junina, Festa do Padroeiro e Semana Oswaldo Cruz: 6 \%

\section{3) Como fica sabendo dessas festas e suas atividades?}

(Podiam responder mais que uma alternativa)

Não respondeu: $1,2 \%$ Responderam: $98,8 \%$

Pela televisão: $\quad 6 \%$

Por amigos: $\quad 39 \%$

Por folhetos: $\quad 39 \%$

Por cartazes: $\quad 46,3 \%$

Pelo rádio: $\quad 46,3 \%$

Qual emissora:

Paraitinga: $\quad 55,2 \%$

Band Vale: $\quad 7,8 \%$

Metropolitana, 94 FM, Taubaté: com 1 citação cada

Outros meios, citados espontaneamente: carro da prefeitura, na escola, calendário oficial, internet, igreja, boca-a-boca, já é tradição. 


\section{4) Que rádios você escuta aqui na cidade?}

(Podiam responder mais que uma alternativa)

Responderam: $98,8 \% \quad$ Não respondeu: $1,2 \%$

Nenhuma: 2,7 \%

Paraitinga: $\quad 86,5 \%$

Band Vale: $\quad 35,3 \%$

Metropolitana: $\quad 17,0 \%$

Jovem Pan: $\quad 9,7 \%$

Viva FM: $\quad 7,3 \%$

Difusora: $\quad 3,6 \%$

Outra, qual:

Nossa Rádio, 97,5 e Gospel: 2 citações

Transamérica, Capital, Taubaté, Tupi, Pop Rock, 99, Canção Nova e 89,9: 1 citação cada

\section{5) Qual a que você mais ouve/prefere?}

Não responderam: $26,5 \%$ Responderam: $73,5 \%$

Paraitinga: $55,8 \%$

Por que: pega melhor, é daqui da cidade/falada cidade, é interessante, outras não pegam.

Band Vale: $23 \%$

Por que: pega bem, tem boa música, já estou acostumado, sinal mais forte, informações da estrada, menos comercial, mais notícia, mais música.

Jovem Pan: $8,2 \%$

Por que: pelo estilo jovem de música

Rede Viva: $6,5 \%$

Porque tem música de viola, gosta da programação, tem música.

Com uma citação cada, $1,62 \%$ cada, total $6,5 \%$ :

Difusora, porque conseguiu emprego

Gospel FM, não justificou

Nossa Rádio: porque é evangélica

Metropolitana: pela variedade de música.

\section{6) Você ouve a Rádio Paraitinga?}

Não responderam: $13,3 \%$ Responderam: $86,7 \%$

Sim: $88,9 \%$

Por que: é legal, é a única que pega, porque é da cidade, fala da cidade, pega melhor.

Não: $\quad 11,1 \%$ 
Por que: prefere rádio religiosa, não toca música de raiz, os locutores são ruins, as músicas são antigas, locutores são lentos, tocam sempre as mesmas músicas.

\section{7) "O que eu mais gosto na Rádio Paraitinga é que ela é da cidade e fala dos assuntos da cidade".}

Não responderam: $16,8 \%$ Responderam: $83,1 \%$

Concordo totalmente: $82,6 \%$

Porque: é bom ouvir coisas daqui, muita informação, programação voltada para a cidade, porque é nossa querida radinha, a rádio fala de tudo da cidade, é importante para a cidade, tem noticias, divulgação e política, fala bem da nossa cidade, a gente fica sabendo das coisas, é a única que fala dos assuntos da cidade, é muito bom para nós pois a gente sabe das coisas da nossa cidade, o povo fica informado, falam que aqui (Alto do Cruzeiro) é área de risco.

Concordo em parte: + Discordo em parte: - Somados: $17,4 \%$

Discordo totalmente: 0

Porque: deveria falar de outras cidades, fala pouco da cidade, não gosto tanto, não fala dos assuntos da cidade, a rádio deveria dar mais atenção ao pessoal do Alto do Cruzeiro,

fala da política, mas do lado dos políticos, fala das coisas que nem sempre interessam para a cidade, às vezes tem muita propaganda, é mais preocupada com lucro.

\section{8) Quais os programas da Rádio Paraitinga que você prefere?}

Obs.: Todos responderam e podiam optar por mais de um.

Das 7 h00 às 9 h00 Sertanejo Regional- $28,9 \%$

Das $9 \mathrm{~h} 00$ às $11 \mathrm{~h} 30$ Música Variada $\quad-27,7 \%$

Das $11 \mathrm{~h} 30$ às $12 \mathrm{~h}$ Jornal Paraitinga - $18 \%$

Das 5 h00 às 7 h00 Raiz Sertaneja $\quad-18 \%$

Das $13 \mathrm{~h}$ às $16 \mathrm{~h} \quad$ Paraitinga Music $\quad-16,8 \%$

Na seqüência:

Santo Terço (18h às $18 \mathrm{~h} 30)-12 \%$

Seleção Brasileira (16h às 17h) - $8 \%$

Let's Rock (17h às $18 \mathrm{~h}$ ) e Paraitinga Hits (18h30 às $19 \mathrm{~h})-7 \%$

Música Pop Variada (19h às 20h) e Noite de Sucessos (20h às $22 \mathrm{~h}$ ) - $6 \%$

Músicas Variadas (22h às 22h30), Let’s Rock na Madrugada (0h à 1h) e Noite a fora ( $1 \mathrm{~h}$ às $5 \mathrm{~h})$ - 1 citação cada

Meia Hora Dance (22h30 às 23h) e Meia Hora Black (23h30 à 0h) - 0 


\section{Especiais}

Estrada do Sertão (domingos, das $7 \mathrm{~h} 30$ às $9 \mathrm{~h} 30$ ) - $\quad 16,8 \%$

Paraitinga da Saudade (sábados)

Todos os Ritmos (domingos, 12h às 15h)

Anarquia Cultural (quintas, das $22 \mathrm{~h}$ às $0 \mathrm{~h}$ )

- $\quad 9,6 \%$

- $\quad 9,6 \%$

$-6 \%$

\section{Religiosos}

A Voz da Paróquia (sextas, das $12 \mathrm{~h}$ às $13 \mathrm{~h}$ ) - $\quad 18 \%$

Viva a Vida (domingos, $9 \mathrm{~h}$ às $12 \mathrm{~h}$ )

- $\quad 7 \%$

Assembléia de Deus (segundas e quintas, das $21 \mathrm{~h}$ às $22 \mathrm{~h}$ ) - 1 citação

\section{9) Quais dos serviços prestados pela Rádio Paraitinga já foram úteis pra você?}

Não responderam: $24 \%$

Responderam: $\quad 76 \%$

Não usaram: $12 \%$ Usaram todos: 2 citações

\begin{tabular}{ll} 
Dicas de Saúde & $47 \%$ \\
Notas Sociais & $38 \%$ \\
Ajuda & $19 \%$ \\
Oferta de empregos & \multicolumn{2}{c}{1 citação apenas } \\
Outros & $17 \%$
\end{tabular}

Anúncios: $8 \%$

Prestação de Contas Associação, Divulgação de Projeto, pediu emprego e notícia de

óbito - 1 citação cada

\section{0) O que você não gosta na Rádio Paraitinga?}

Não responderam: $30,1 \%$ Responderam: $69,9 \%$

Está tudo certo com a rádio: $41,3 \%$

Não toca música de raiz, não toca Hip Hop, não toca funk, não gosto de rock, sempre as mesmas músicas, faltam músicas modernas, falta variedade musical, gostaria de ouvir música, repete muito a mesma música, muita música sertaneja.

Locutores se atrapalham para falar, locutores falam errado, locutores são lentos, locutores falam muito caipira.

De programas religiosos, de futebol, do jornal, muita propaganda, não fala de coisas de outras cidades, muito bate-papo, programas com conversas bobas, comerciais feitos de um jeito caipira.

Deveria falar mais de utilidade pública, mais dicas de saúde, anunciar campanhas de saúde e festas com mais antecedência. Acho que ela não é comunitária. 
11) Como os locutores falam nos programas, que tipo de palavras ou expressões eles usam e que mais têm a ver com seu jeito de falar ou com o jeito da cidade?

Não responderam: $\quad 35 \% \quad$ Responderam: $\quad 65 \%$

Sotaque caipira/jeitão sertanejo/jeito daqui $\quad 50 \%$

Falam errado/.pouco preparados $\quad 22 \%$

Nada especial $7 \%$

Outras: falam rápido, com simplicidade, "mestre", "nói”.

12) Você já participou de algum programa da Rádio?

Não responderam: $8,5 \%$ Responderam: $91,5 \%$

Não: $53 \%$ Sim: $38 \%$

Programa Gravado: $6,2 \%$

Programa ao Vivo: $15,6 \%$

Como foi sua apresentação:

Por telefone: $68,7 \%$

No estúdio: $\quad 12,5 \%$

Assunto: apresentou-se com grupo para cantar, fazendo campanha para Conselho Tutelar, entrevista sobre capoeira.

Pessoalmente: $12,5 \%$

Por carta: $\quad 0$

Assunto: por telefone e pessoalmente: pedindo música: $\quad 23,6 \%$ sorteio de brindes: $\quad 7,9 \%$

Outros:

Obs.: Houve respostas com as duas alternativas.

Procura de pessoa perdida, anunciar aniversário, anunciar óbito.

13) A Rádio Paraitinga apóia as festas da cidade?

Não responderam - 15,6 \% Responderam - 84,4 \%

Sim $-100 \%$ dos que responderam

Não - nenhuma citação

Como:

Divulgando com antecedência - 95,7 \%

Informando sobre as atividades da festa $\quad-75,7 \%$

Orientando mudanças no cotidiano da cidade - 55,7\% 


\section{4) É importante preservar as festas tradicionais da cidade?}

Não responderam - 13,2 \% Responderam - 86,8 \%

Sim $-98,6 \% \quad$ Não $-1,4 \%$

Por quê?

Continuidade das nossas tradições e da história da cidade $\quad 80,5 \%$

O povo precisa das festas para se encontrar

Atrai gente de fora,melhora o comércio $\quad 47,2 \%$

Obs.: houve respostas com mais de uma alternativa

Outras respostas: pela religião; encontrar novas pessoas; pela cultura; é bom para o turismo; para manter identidade do povo; para os mais velhos passarem tradições aos mais jovens; a cidade é festa!; atrai gente mas não melhora muito o comércio.

\section{5) O que mais ajuda para que as festas aconteçam todos os anos?}

Não responderam - $12 \% \quad$ Responderam - $88 \%$
Cartazes/folhetos
- $24,6 \%$
Ação da igreja
$-27,4 \%$
Ação da Prefeitura
- $39,7 \%$
Divulgação pela TV
- $12,3 \%$

Outras:

$\begin{array}{ll}\text { Mobilização do povo } & -12,3 \% \\ \text { Revistas e metrô em SP } & -1 \text { citação } \\ \text { Internet } & -2 \text { citações } \\ \text { Turistas } & -1 \text { citação }\end{array}$

Divulgação pelo Rádio $\quad 46,5 \%$

Quais:

Rádio Paraitinga - 61,7\%

Rádio Band Vale - 2 citações

Rádio Difusora - 1 citação

Comentários dos pesquisados: Deve-se manter o povo da roça na roça para manter e preservar festas tradicionais. Todos têm que trabalhar juntos para isso. Participação de todos é muito importante. O povo ajuda muito para as festas acontecerem.

16) Qual a principal razão pela qual as pessoas da cidade participam das festas?

Não responderam - $18 \% \quad$ Responderam - $82 \%$ 
O pessoal da cidade é festeiro - $23,5 \%$

Tradição

Diversão

Religiosidade/Fé
- $23,5 \%$

- $32,3 \%$

- $26,4 \%$

Obs.: houve respostas com mais de uma alternativa.

Outras: Atrair turistas para as festas não acabarem. Já é a vida da cidade. Bom pra o comércio. Orgulho do povo, passar boa imagem.

\section{7) Quantos aparelhos de rádio você tem em casa?}

Não responderam
$\begin{array}{llc}0 & - & 2,5 \% \\ 1 & - & 50,6 \% \\ 2 & - & 29,1 \% \\ 3 & - & 13,9 \% \\ 4 & - & 2,6 \% \\ 5 & - & 1,3 \%\end{array}$

\section{Comentários espontâneos dos pesquisados:}

Faixa etária - 15 a 25 anos - homens

"É interessante para a cidade ter uma rádio comunitária. Ajuda a manter as festas mas poderia fazer mais".

"O acesso de muita gente na cidade modifica o cotidiano e a festa. Os mais velhos gostariam de preservar as festas, os jovens nem tanto. A família da Dona Cinira (viúva do Elpídio dos Santos) procura preservar".

"Deveria ter mais festas. Ter feiras de artesanato nos fins de semana".

\section{Faixa etária - 15 a 25 anos - mulheres}

"É importante que o turista conheça os casarões de pau-a-pique, a preservação do patrimônio. Seria importante que nas escolas se ensinasse as danças tradicionais para preservar".

"Às vezes as festas são importantes porque o luizense recebe parentes e o povo que vem de fora para as festas".

"Achei muito interessante a pesquisa e muito bom se estudar sobre isso aqui".

"Fico sabendo das festas pelas pessoas e também pelo calendário já tradicional. Todo mundo sabe quando vai acontecer".

"Para divulgar melhor as festas: cartazes da prefeitura, igreja (as festas religiosas) e o boca-a-boca. A rádio comunitária é muito importante para a cidade, senão ficamos carentes de informação. A rádio ajuda a preservar as festas. É importante para a cultura local: danças típicas, músicas, sentido religioso". 
"As pessoas querem manter as tradições. Sei que existia uma associação, a AACULT, não sei se ainda existe, nunca soube de alguma ação cultural promovida por ela".

\section{Faixa etária - 26 a 45 anos - homens}

"Participo mais das festas rurais".

"Na época das festas falta policiamento, especialmente no Carnaval e também falta infra-estrutura, especialmente banheiros".

"A questão política atrapalha, há conflitos de poder".

"Nas festas religiosas a participação do jovem é menor".

"O que mais ajuda nas festas é a ação da Prefeitura, mas ela se preocupa mais com o lucro que a festa pode dar".

"É preciso fazer algo para que o Santander Banespa preserve o casarão que ocupa na praça. Sugiro que eles construam um Centro Cultural no piso superior que está muito deteriorado".

"Tem coisa que está acabando nas festas. A Prefeitura deveria apoiar mais. Por exemplo, o pessoal da Congada se apresenta sem nenhum apoio, nem para transporte".

\section{Faixa etária - 26 a 45 anos - mulheres}

"A Rádio Paraitinga apóia as festas muito mesmo, Nossa Senhora Aparecida! Até nas roças. É importante preservar as festas porque é a nossa cultura, nossas festas, nossos casarões, nosso Oswaldo Cruz".

"Já que não tem emprego, vamos de festas. Vamos festejar. As nossas festas beneficiam a gente. São portas que abrem: restaurante, barraquinha, a gente pode vender as coisas que a gente faz".

"A Rádio Paraitinga é uma das melhores coisas da cidade. Teve mais duas e a nossa Paraitinga ficou firme".

"A Rádio passa lá na igreja e pega tudo que precisa ser anunciado, o Benedito Domingos é quem dá o que precisa ser anunciado".

"O pessoal de fora curte muito as festas. É muito participativo". Todos precisam ajudar para a continuidade das festas. Cada um faz uma parte e acaba por fazer uma divulgação completa".

"Quando não vai ter uma festa, há críticas porque a tiraram".

"Festas tradicionais é a única coisa boa em Paraitinga".

"Nossa! Não pode fechar a Rádio, de jeito nenhum! Ela transmite a missa ao vivo. Tem que ter a Rádio no ar. Precisa de bons locutores para falar bem bonito as coisas bonitas da cidade".

"Quando tiver outra entrevista eu quero colaborar, eu adorei falar e contribuir". "Eles divulgam as festas pelo nome das ruas, ninguém sabe onde é. Tem que falar que é a rua onde mora o fulano, da padaria do fulano, etc.".

\section{Faixa etária - acima de $\mathbf{4 5}$ anos - homens}

"O povo ajuda muito para as festas".

"Precisava resgatar a essência da cidade pela educação. Recuperar danças catira e jongo, por exemplo. Na Secretaria Municipal de Cultura falta apoio pra resgatar músicas de raiz. Festa do Saci é resgate da cultura popular. As festas trazem mais movimento, é bom para o comércio, mas também traz drogas, violência, etc.". 
Faixa etária - acima de $\mathbf{4 5}$ anos - mulheres

"A Rádio Paraitinga fica sintonizada no Salão de Beleza o dia todo".

"As festas têm que se voltar para o turismo, mudar a cabeça do povo e dar mais valor para o turista. Só o Carnaval e o Festival de Inverno são voltados para o turismo".

"Aqui é Festa, acaba uma e já vem outra. Se acabarem as festas acaba a cidade. Já nos acostumamos a viver das festas. Mas já acabou muita coisa e não devia".

"Os padres ditam as festas, preferem como era no passado".

"O padre fez mudanças que os mais velhos não gostaram".

"Desculpe, não respondi várias, minha cabeça não funciona bem por causa da diabetes. É fácil saber quando tem festa. Festa é o que mais tem na cidade".

"É preciso mais apoio da Prefeitura. Precisa resgatar em São Luis as pessoas que poderiam colaborar culturalmente". 


\section{ANEXO VI}

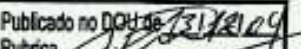

Ritrica 27 s

ATO $N^{\circ} 48.364$, DE 9 DE DEZEMBRO DE 2004.

O SUPERINTENDENTE DE SERVIÇOS DE COMUNICACÃ̃o dE MASSA DA AGÊNCIA NACIONAL DE TELECOMUNICACCÕES - ANATEL, no uso de suas competéncias, consoante o disposto nos incisos Vl e VIII do art. 198 do Regimento Interno da Agencia Nacional de Telecomuricaçōes - Anatel, aprovado pela Resolução $n^{\circ} 270$, de 19 de julho de 2001 e considerando, ainda, o que consta da Resoluçăo ANATEL n' 387, de 03 de novembro de 2004 e do Processo n ${ }^{\circ} 53500.032171 / 04$

RESOLVE:

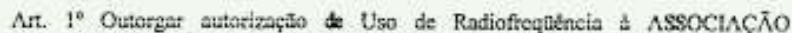
CULTURAL PARA DIFUSÃo DAS TRADIC̄ōES E HÁBITOS LUIZENSES, entidade autorizada a executar o Serviço de Rudjodifisaño Comunitária, na localidade de Sä́o Luis do Paraitinga, Estado de Sato Paulo, visando a utilizaçato da frequitncia $105,9 \mathrm{M} ! \mathrm{lz}$, correspondente ao canal 290 da faixa de FM, na execuçào do referido serviço.

Art. $2^{\circ}$ Fixar o valor de RS 100,00 (cem reais) referente ao preço público pelo direito de uso da radiofrequéncia autorizada no art. $1^{2}$.

Art. $3^{\circ}$ Estabelecer que a entrada em vigor da presente autorizaçắ de uso da radiofreqoência está condicionada da efetivaço do recolbimento do valor fixado no art $2^{b}$ e

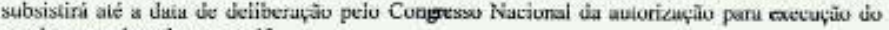
serviço mencionado no art. $1^{\circ}$.

Art. $4^{\circ}$ Este Ato entra em vigor na data de sua publicaç.̃o.

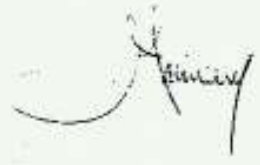

ARA APKAR MINASSIAN

Superintendente de Serviços de Comunicação de Massa

\section{Anexo VI}

